\title{
पब्ति
}

INSTITUTO DE PESQUISAS ENERGÉTICAS E NUCLEARES

Autarquia associada à Universidade de São Paulo

\section{AVALIAÇÃO DA COMPRESSIBILIDADE DE MISTURAS DE PÓS DE NIÓBIO E ALUMÍNIO ATIVADAS MECANICAMENTE}

\author{
MARIANO CASTAGNET
}

Dissertação apresentada como parte dos requisitos para obtenção do grau de Mestre em Ciências na Área de Tecnologia Nuclear - Materiais.

Orientador:

Dr. Ricardo Mendes Leal Neto 


\title{
प्बत
}

INSTITUTO DE PESQUISAS ENERGÉTICAS E NUCLEARES

Autarquia associada à Universidade de São Paulo

\section{AVALIAÇÃO DA COMPRESSIBILIDADE DE MISTURAS DE PÓS DE NIÓBIO E ALUMÍNIO ATIVADAS MECANICAMENTE}

\author{
MARIANO CASTAGNET
}

Dissertação apresentada como parte dos requisitos para obtenção do grau de Mestre em Ciências na Área de Tecnologia Nuclear - Materiais.

Orientador:

Dr. Ricardo Mendes Leal Neto 


\title{
AVALIAÇÃO DA COMPRESSIBILIDADE DE MISTURAS DE PÓS DE NIÓBIO E ALUMÍNIO ATIVADAS MECANICAMENTE
}

\author{
Mariano Castagnet
}

\begin{abstract}
RESUMO
Este trabalho trata da avaliação da compressibilidade de misturas de pós de nióbio e alumínio, previamente ativadas por moagem de bolas de alta energia. Foram variados o tempo de moagem e a quantidade de ácido esteárico, adicionado como agente controlador de processo (ACP), assim como o tamanho médio de partícula do pó de alumínio. Os pós de partida e as misturas moídas foram caracterizados por microscopia eletrônica de varredura (forma das partículas) e por difração de raios laser (distribuição granulométrica). Uma máquina universal de ensaios foi utilizada nos testes de compressibilidade mediante compactação das amostras numa matriz cilíndrica de aço-ferramenta. Os dados de compressibilidade foram comparados graficamente segundo curvas de densidade (relativa) versus pressão. As diferenças de comportamento na compactação das amostras foram correlacionadas com as diferentes condições de moagem. Houve um decréscimo da compressibilidade com o aumento do tempo de moagem e da quantidade de ACP. Menos compressíveis foram também as misturas provenientes do pó de alumínio com maior tamanho de partícula. Uma nova equação de compactação foi ainda proposta, cujo ajuste aos dados deste trabalho foi superior aos verificados nas equações de modelos anteriormente publicados.
\end{abstract}




\title{
COMPRESSIBILITY EVALUATION OF MECHANICALLY ACTIVATED NIOBIUM AND ALUMINUM POWDERS MIXTURES
}

\author{
Mariano Castagnet
}

\begin{abstract}
This work deals with compressibility evaluation of mechanically activated niobium and aluminum powder mixtures by high-energy ball milling. Milling time and quantity of stearic acid, added as a process control agent (PCA), were varied, as well as the mean particle size of the aluminum powder. Starting powders and as-milled mixtures were characterized by SEM (particle shape) and laser diffraction analysis (particle size distribution). A universal testing machine was used for the compressibility tests carried out in a cylindrical die of tool steel. Sample compressibility data were compared by plotting relative density-pressure curves. Different compaction behavior between samples was correlated to the various milling conditions. Compressibility was seen to decrease by increasing milling time and quantity of PCA. Mixtures from aluminum powder with larger particle size were also less compressible. A new compaction equation could be further provided, showing better fitting to the data of this work when compared to the equations from previous reported models.
\end{abstract}


Dedico este trabalho a meu pai, Antonio (in memoriam), minha mãe, Matilde, minha esposa Regilda e minha filha, Bárbara. 


\section{AGRADECIMENTOS}

Ao Prof. Dr. Ricardo Mendes Leal Neto, meu orientador nesta dissertação, exemplo de ética profissional pelo incentivo, cuidado e paciência ao longo de todo este trabalho e, principalmente, por ter me dado a oportunidade de fazer parte de sua equipe de pesquisa.

Ao Dr. José Roberto Martinelli e sua equipe pelo cuidado e presteza na realização das análises granulométricas.

A meus amigos Celso e Nildemar pelas micrografias de MEV, Glauson pelo auxílio e idéias na parte de metalografia e Rene pelo difratograma de raios $\mathrm{X}$..

Aos membros da banca Dr. Paulo Íris Ferreira e Dr. Jesualdo Luiz Rossi, pelo tempo dedicado à análise crítica desta dissertação.

A todos aqueles que, direta ou indiretamente, tenham contribuído para a realização deste trabalho. 


\section{SUMÁRIO}

Página

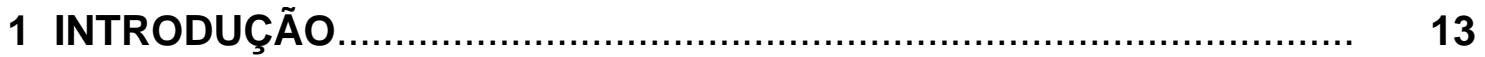

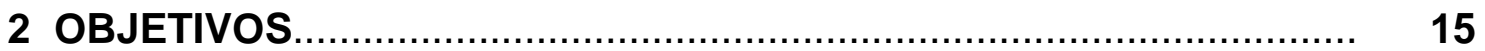

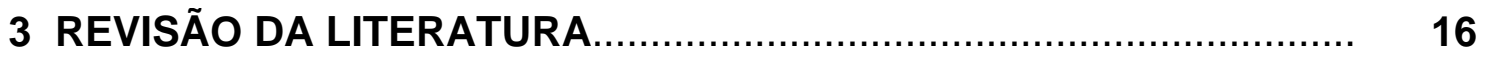

3.1 Compostos intermetálicos................................................... 16

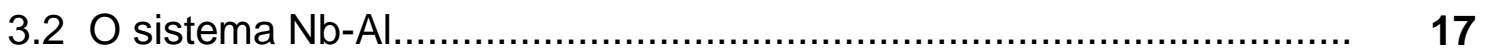

3.3 Moagem de alta energia............................................... 17

3.3.1 Ativação mecânica............................................................. $\quad 19$

3.3.2 Tipos de moinhos de bolas.................................................. 20

3.3.2.1 Moinhos agitadores ("shaker mill").................................. 20

3.3.2.2 Moinhos do tipo planetário............................................. 21

3.3.2.3 Moinhos atritores......................................................... $\quad 21$

3.3.2.4 Moinhos convencionais (jarra) ..................................... 22

3.3.3 Recipiente e bolas de moagem.................................... 23

3.3.4 Variáveis de processo............................................................ 23

3.3.4.1 Velocidade de moagem..................................................... 23

3.3.4.2 Tempo de moagem .................................................. 24

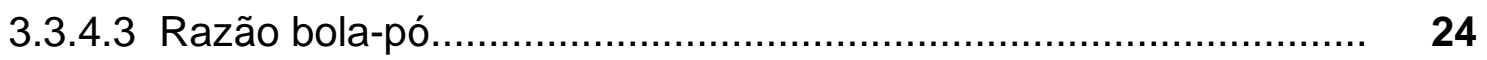

3.3.4.4 Quantidade de pó............................................................. $\quad 25$

3.3.4.5 Agente controlador de processo- ACP............................... 25 
3.4 Síntese por combustão mecanicamente ativada .............................. $\quad 26$

3.5 Compressibilidade e compactação de pós........................................... 27

3.5.1 Fatores extrínsecos............................................................. $\quad \mathbf{2 8}$

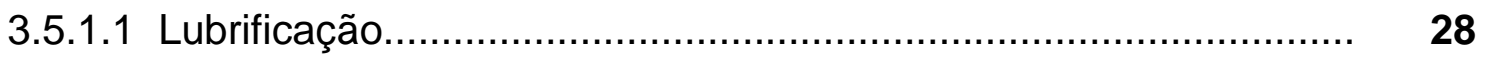

3.5.1.2 Velocidade de compactação...................................................... 29

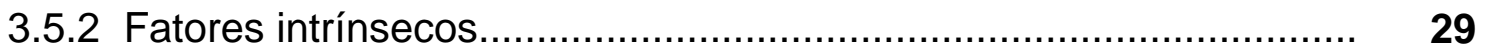

3.5.2.1 Tamanho, forma e área de superfície específica das partículas.... $\quad 29$

3.5.2.2 Encruamento e dureza das partículas........................................ $\quad 29$

3.5.2.3 Quantidade e tipo de ACP ................................................... 29

3.5.3 Modelos de compactação......................................................... 29

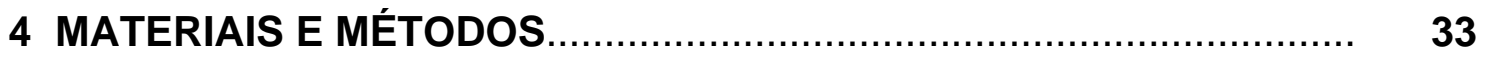

4.1 Ensaios de compressibilidade: definição do procedimento................... 33

4.1.1 Determinação da rigidez do sistema (testes em vazio).................. $\quad 33$

4.1.2 Compactação de pós - correção das curvas de compressibilidade.. 35

4.1.3 Compactação de pós - variação do apoio da matriz......................... 36

4.1.4 Compactação de pós - velocidade de compactação......................... 38

4.2 Ensaios de compressibilidade: misturas ativadas mecanicamente .... $\quad 39$

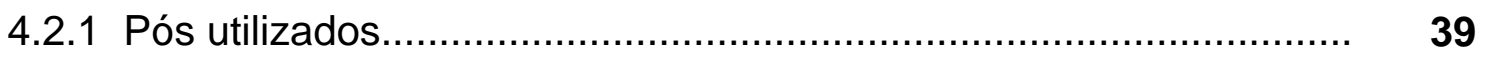

4.2.1.1 Pós de alumínio (Al).......................................................... $\quad 39$

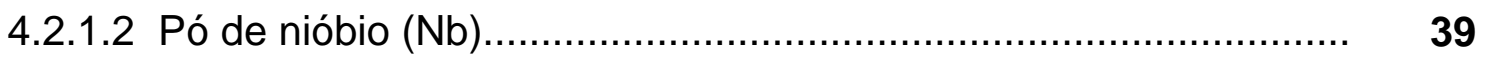

4.2.2 Ativação mecânica por moagem de alta energia............................... 39

4.2.3 Dados obtidos nas compactações................................................. $\quad 40$ 
4.3 Caracterização........................................................................ 4

4.3.1 Analise granulométrica dos pós................................................... 41

4.3.2 Microscopia eletrônica de varredura (MEV)................................... $4 \mathbf{4 1}$

4.3.3 Difração de raios X............................................................... 4

5 RESULTADOS E DISCUSSÃO.......................................................... 42

5.1 Caracterização dos pós de alumínio e nióbio de partida....................... 42

5.1.1 Pós de alumínio.......................................................................... 42

5.1.2 Caracterização do pó de nióbio.................................................... 46

5.2 Caracterização das misturas de pós mecanicamente ativadas........... $\quad 47$

5.2.1 Microscopia eletrônica de varredura e análise do tamanho de

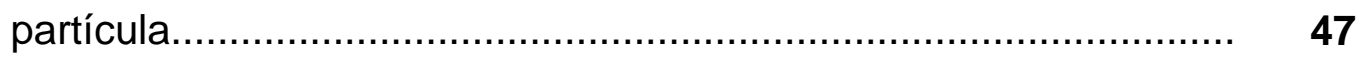

5.2.2 Curvas de compressibilidade ................................................... 63

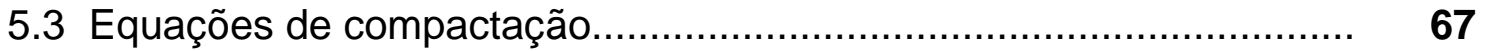

6 CONCLUSÕES

7 SUGESTÕES PARA TRABALHOS FUTUROS.................................. 75

REFERÊNCIAS BIBLIOGRÁFICAS .................................................. 76 


\section{LISTA DE TABELAS}

PÁG.

Tabela 1- Coeficientes da equação de calibração e $\mathrm{R}^{2}$ para 121 pontos de leitura

Tabela 2- Resultados da distribuição do tamanho de partícula dos pós de alumínio L1 e L2

Tabela 3- Resultados da distribuição do tamanho de partícula do pó de nióbio.

Tabela 4- Tamanhos médios de partícula $(\mu \mathrm{m})$ das misturas NbAl, ativadas mecanicamente em diversas condições.

Tabela 5- Expressões de $f(D)$ (ou $f(P, V)$, para a eq. de Kawakita e Lüdde) e $f(P)$ das equações de compactação encontradas na literatura.

Tabela 6- Coeficientes $\boldsymbol{A}$ e $\boldsymbol{B}$ das retas ajustadas aos dados segundo os modelos de compactação analisados neste trabalho. 


\section{LISTA DE FIGURAS}

PÁG

Figura 1- Esquema das fases do processo de moagem de misturas de pós dúcteis.

Figura 2 Esquema de um moinho agitador $(A)$, planetário (B), atritor (C) e moinho convencional (D)....

Figura 3 Deslocamento do travessão (teste em vazio) x Carga de compressão e ajuste polinomial da curva obtida.

Figura 4 Curvas de correção do sistema (vermelha), de compactação da amostra sem correção (azul) e de compactação da amostra corrigida (preta).

Figura 5 Curvas de deslocamento x carga obtidas na compactação de pós de níquel em três diferentes condições.

Figura 6 Curvas de 4 ensaios de compactação de pó de Ni com variação nas velocidades do travessão $(2 ; 3,5$ e 10 $\mathrm{mm} / \mathrm{min})$

Figura 7 Micrografias de varredura (elétrons secundários) dos pós de Al L1 (parte superior) e Al L2 (parte inferior) antes da moagem

Figura 8- $\quad$ Distribuição do tamanho de partícula dos pós Al L1 (A) e Al L2 (B).

Figura 9 Curvas de compressibilidade dos pós de alumínio Al L1 e Al L2

Figura 10 Micrografia (A) e o gráfico da distribuição de partículas do pó de nióbio (B).

Figura 11A- Micrografias de varredura (imagem de elétrons retroespalhados) da forma e da microestrutura dos agregados das misturas, ativadas mecanicamente por $0,5 \mathrm{~h}$, com $1 \%$ de ACP 
Figura 11B- Micrografias de varredura (imagem de elétrons retroespalhados) da forma e da microestrutura dos agregados das misturas ativadas mecanicamente por 0,5 h, e $2 \%$ ACP

Figura 12- Distribuição granulométrica das misturas NbAl L1 (A) e NbAL2 (B) ativadas por $0,5 \mathrm{~h}$, com $1 \%$ de ACP. A mistura $\mathrm{NbAl}$ L2 apresentou agregados maiores que $500 \mu \mathrm{m}$, o que fez com que a escala máxima do analisador fosse ultrapassada, prejudicando o resultado..............................

Figura 13- Distribuição granulométrica das misturas NbAl L1 (A) e NbAL2 (B) ativadas por 0,5 h, com 2\% de ACP..................

Figura 14A- Micrografias de varredura (imagem de elétrons retroespalhados) da forma e da microestrutura dos agregados das misturas ativadas mecanicamente por $1 \mathrm{~h}$ e $1 \%$ ACP.

Figura 14B- Micrografias de varredura (imagem de elétrons retroespalhados) da forma e da microestrutura dos agregados das misturas, ativadas mecanicamente por $1 \mathrm{~h}$ e $2 \%$ ACP.

Figura 15- Distribuição granulométrica das misturas NbAl L1 (A) e NbAl L2 (B) ativadas por $1 \mathrm{~h}$, com 1\% de ACP. A mistura NbAl L2 apresentou agregados maiores que $500 \mu \mathrm{m}$, acima do limite de detecção do equipamento............................................

Figura 16- Distribuição granulométrica das misturas NbAl L1 (A) e $\mathrm{NbAL} 2$ (B) ativadas por $1 \mathrm{~h}$, com $2 \%$ de ACP.....................

Figura 17A- Micrografias de varredura (imagem de elétrons retroespalhados) da forma e da microestrutura dos agregados das misturas ativadas mecanicamente por $2 \mathrm{~h}$ com $1 \%$ ACP

Figura 17B- Micrografias de varredura (imagem de elétrons retroespalhados) da forma e da microestrutura dos agregados das misturas, ativadas mecanicamente por $2 \mathrm{~h}$ e $2 \%$ de ACP

Figura 18- Distribuição granulométrica das misturas NbAl L1 (A) e NbAL2 (B) ativadas por 2 horas, com 1\% de ACP............... 
Figura 19- Distribuição granulométrica das misturas NbAl L1 (A) e NbAL2 (B) ativadas por 2 horas, com 2\% de ACP................

Figura 20- Micrografias de varredura (imagem de elétrons retroespalhados) da forma e da microestrutura dos agregados das misturas $\mathrm{L} 1$ e $\mathrm{L} 2$ ativadas mecanicamente por 2,5 h.......

Figura 21- Distribuição granulométrica das misturas NbAl L1 (A) e NbAL2 (B) ativadas por 2,5 h, com 1\% de ACP.....................

Figura 22- Difratograma de raios $X$ da mistura $L 2$ ativada por 2,5 horas e $1 \%$ de ACP, mostrando que não houve a formação de fase intermetálica durante o processo de moagem.................

Figura 23- Curvas de compressibilidade (densidade relativa $x$ pressão) das amostras ativadas por $0,5 \mathrm{~h}$ com $1 \%$ de ACP (A) e $2 \%$ de ACP (B), e por $1 \mathrm{~h}$ com $1 \%$ de ACP (C) e $2 \%$ de ACP (D) 64

Figura 24- Curvas de compressibilidade (densidade relativa $x$ pressão) das amostras ativadas por $2 \mathrm{~h}$ com $1 \%$ de ACP (E), com $2 \%$ de ACP (F) e por 2,5 h com 1\% de ACP (G) .......................

Figura 25 Curvas de aplicação da nova equação de compactação aos dados das amostras deste trabalho. Os coeficientes de correlação linear (R) estão indicados em cada gráfico............

Figura 26- Curvas de aplicação da nova equação de compactação aos dados das amostras deste trabalho. Os coeficientes de correlação linear $(R)$ estão indicados em cada gráfico...........

Figura 27- Curvas de aplicação da nova equação de compactação aos dados das amostras deste trabalho, nas condições de tempo de $0,5 \mathrm{~h}$ (quatro gráficos superiores) e 2,5 h (gráficos inferiores). Os coeficientes de correlação linear (R) estão indicados em cada gráfico 


\section{INTRODUÇÃO}

A metalurgia do pó (M/P) é uma técnica que consiste na fabricação de pós metálicos e na sua conformação e consolidação, geralmente por compactação e sinterização, em temperaturas abaixo do ponto de fusão do metal base, obtendose produtos com precisão dimensional e propriedades mecânicas passíveis de controle.

A técnica de metalurgia do pó vem sendo utilizada pelo homem há milênios. Porém, sob o ponto de vista industrial, a obtenção de peças sinterizadas se consolidou apenas mais recentemente, a partir da $2^{\text {a. }}$ Guerra Mundial. As etapas de desenvolvimento mais importantes ocorreram no início do século $X X$, com o domínio dos processos de fabricação de pós por redução, eletrólise e atomização, e o estudo da possibilidade da fabricação de peças de metais refratários de alto ponto de fusão, como o tungstênio e o molibdênio, limitados pelos processos metalúrgicos da época. Nas etapas seguintes houve um aumento na performance da M/P, oferecendo um melhor controle da microestrutura, homogeneidade e materiais com propriedades mecânicas em níveis iguais ou melhores aos produtos obtidos por fundição ou conformação mecânica.

O rápido crescimento que esta técnica vem experimentando nos últimos anos é atribuído a fatores como: redução do número de operações na produção da peça acabada em relação a outros processos, aproveitamento quase total da matéria prima, e produção em grande escala de peças de dimensões e formas iguais ou muito próximas das definitivas sem praticamente necessidade de qualquer operação final de usinagem ou acabamento. Dentre as principais desvantagens estão o alto custo do ferramental envolvido, que envolve prensas e matrizes, essas últimas muitas vezes complexas e sujeitas ao desgaste, a limitação das formas que se pode obter e a limitação de tamanho das peças, imposta pela capacidade da prensa usada para a compactação dos pós.

Dentre as diversas técnicas de metalurgia de pó existentes, a síntese por combustão, combinada com a moagem de alta energia e vem sendo estudada há cerca de dez anos pelo grupo de intermetálicos do Centro de Ciência e Tecnologia de Materiais (CCTM) do Instituto de Pesquisas Energéticas e Nucleares (IPEN). Neste caso a moagem de alta energia tem sido empregada 
para ativar mecanicamente misturas de pós dos elementos que constituem os compostos intermetálicos e assim possibilitar um maior controle das reações de combustão envolvidas na síntese destes materiais.

A compactação de misturas ativadas mecanicamente é uma etapa que antecede a síntese por combustão. Pós diferentemente ativados deverão apresentar comportamento sob compactação também diferente. A identificação e a análise de tais diferenças poderão fornecer pistas para se antecipar ou explicar comportamentos da mistura durante as reações de síntese por combustão, ou no mínimo serão úteis como parâmetro de controle da ativação mecânica. Tais aspectos foram os motivadores da proposta deste trabalho. 


\section{OBJETIVOS}

O objetivo principal deste trabalho é correlacionar algumas variáveis de ativação mecânica com alterações das curvas de compressibilidade de misturas de pós de $\mathrm{Nb}$ e Al (proporção atômica 1:3), apresentando embasamento fenomenológico. Adicionalmente, pretende-se verificar o ajuste dos dados de compressibilidade obtidos com modelos pertinentes levantados na literatura; 


\section{REVISÃO DA LITERATURA}

\subsection{Compostos intermetálicos}

Um composto intermetálico pode ser definido como uma fase constituída de dois ou mais elementos metálicos (ou metalóides), cuja rede cristalina difere daquelas dos seus elementos constituintes. Há uma razão de abundância relativamente fixa entre tais elementos, e são geralmente ordenados (a longa distância) em duas ou mais sub-redes, cada uma com sua própria população distinta de átomos ${ }^{[1]}$.

Os compostos intermetálicos constituem uma classe de materiais que apresentam excelentes propriedades físicas e mecânicas, tais como: elevado ponto de fusão e módulo de elasticidade, alta tensão de escoamento, baixa mobilidade atômica, entre outras. Tais características são resultantes das fortes ligações químicas e da estrutura cristalina ordenada destes materiais, a qual provoca uma limitação na mobilidade de discordâncias, proporcionando uma maior resistência mecânica em temperaturas elevadas ${ }^{[2]}$.

Entre os compostos intermetálicos mais estudados encontram-se os aluminetos e os silicetos. Um conjunto de propriedades como alta resistência mecânica e à oxidação em elevadas temperaturas, acrescidas de uma baixa massa específica, os tornam potencialmente atraentes para aplicações estruturais em altas temperaturas. Entretanto, sua elevada fragilidade à temperatura ambiente, aliada a algumas dificuldades de processamento, em razão dos altos pontos de fusão e baixa ductilidade, limitaram no passado, e em alguns casos ainda limitam as aplicações de muitos destes materiais ${ }^{[2,3]}$.

A descoberta de que o $\mathrm{Ni}_{3} \mathrm{Al}$ policristalino podia ter sua ductilidade significativamente melhorada por intermédio de micro adições de boro ${ }^{[4]}$ renovou 0 interesse por esses compostos a partir de então ${ }^{[4,5]}$. Acrescido a este fator, tem-se reportado em diversos trabalhos que os materiais intermetálicos podem ser obtidos de uma maneira relativamente simples, rápida e barata por meio de reações de combustão ${ }^{[5-14]}$. 


\subsection{O sistema $\mathrm{Nb}-\mathrm{Al}$}

Os compostos do sistema binário $\mathrm{Nb}-\mathrm{Al}$ encontram-se entre os intermetálicos que têm sido considerados como prováveis substitutos de superligas em aplicações envolvendo altas temperaturas ${ }^{[9]}$. Neste sistema, três fases intermetálicas podem ser distinguidas: $\mathrm{Nb}_{3} \mathrm{Al}, \mathrm{Nb}_{2} \mathrm{Al}$ e $\mathrm{NbAl}_{3}$. Dentre elas, o $\mathrm{NbAl}_{3}$ (trialumineto de nióbio) apresenta um elevado ponto de fusão (1680 ${ }^{\circ} \mathrm{C}$ ), possui a menor massa específica $\left(4,54 \mathrm{~g} / \mathrm{cm}^{3}\right)$, decorrente do seu alto teor de alumínio, e é o único que se funde congruentemente ${ }^{[9]}$. Em virtude dessas características, o $\mathrm{NbAl}_{3}$ era antigamente utilizado como camada resistente à oxidação em algumas ligas de nióbio, encontrando atualmente aplicações potenciais na indústria aeroespacial ${ }^{[10]}$. Uma desvantagem apresentada por esses intermetálicos é a elevada fragilidade à temperatura ambiente. Contudo, a ductilidade desses materiais pode ser melhorada pela adição de um terceiro elemento de liga, (como no caso do $\mathrm{Ni}_{3} \mathrm{Al}$ policristalino descrito no item anterior) resultando em uma substancial melhoria de suas propriedades mecânicas ${ }^{[5,10]}$.

\subsection{Moagem de alta energia}

Dois termos diferentes são comumente usados para descrever o processamento de partículas de pós em moinhos de alta energia. A elaboração mecânica de ligas (do inglês mechanical alloying) refere-se ao processo no qual pós de diferentes metais, compostos ou ligas são moídos conjuntamente. Neste processo ocorre uma transferência de material para que seja obtida uma liga homogênea. Por outro lado, a moagem de pós de composição uniforme (por vezes estequiométrica) tais como pós de metais puros, de intermetálicos ou préligados, na qual a transferência de material não é requerida para a homogeneização, é denominada moagem mecânica (mechanical milling). Muito embora o termo mechanical alloying seja genérico e alguns pesquisadores o utilizem tanto para a elaboração mecânica de ligas propriamente dita quanto para a moagem mecânica, a diferença entre ambos deve ser compreendida em termos de transferência ou não de material ${ }^{[15]}$.

A moagem de alta energia em um moinho de bolas caracteriza-se por envolver altas velocidades e freqüências de impacto entre as bolas de moagem e as partículas de pós reagentes, produzindo uma mistura com um elevado grau de 
dispersão e defeitos cristalinos. Esta técnica foi desenvolvida e inicialmente utilizada por John S. Benjamin em 1966, com o objetivo de produzir uma maior dispersão de fase cerâmicas em superligas ${ }^{[16]}$. Atualmente, a moagem de alta energia tem sido utilizada extensivamente para várias outras aplicações, como exposto anteriormente.

O processo de moagem de alta energia é realizado em moinhos cuja característica básica está na energia cinética das bolas utilizadas na moagem. Nos moinhos de baixa energia convencionais, a energia das bolas é proporcional à massa e à altura da queda livre. As partículas presentes na área de choque sofrem uma deformação absorvendo parte dessa energia e podendo chegar à fratura. Nos moinhos de alta energia é aplicada uma aceleração às bolas muito maior que a da gravidade, aumentando consideravelmente a energia cinética.

Quando submetidas à moagem de alta energia, as partículas sofrem sucessivos ciclos de deformação promovendo-se a soldagem e adesão entre si ou a fratura ${ }^{[17]}$. Para materiais frágeis, o evento de fratura das partículas é bem mais freqüente, o que causa uma diminuição do tamanho de partícula e um aumento da área de superfície. No caso de materiais dúcteis, a capacidade de deformação plástica aumenta a probabilidade de soldagem entre as partículas, situação que favorece o aumento do tamanho de partícula e a formação de agregados (grupo de partículas primárias juntas pelas faces, com uma área de superfície específica significativamente menor que a soma da área dos constituintes).

Foram identificadas por Benjamin e Volin ${ }^{[17]}$ quatro fases no processo, no caso de misturas de materiais dúcteis. Na FIG.1, adaptada destes autores, são mostrados os eventos principais desse processo. $\mathrm{Na}$ fase inicial (I), as partículas são deformadas plasticamente, assumindo uma forma achatada. A intensidade dessa alteração de forma depende da ductilidade do material e da energia de impacto das bolas de moagem. $O$ aumento da área de superfície aumenta progressivamente a probabilidade de soldagem a frio dessas partículas, acarretando um aumento do tamanho médio de partícula. A segunda fase é caracterizada pela predominância do evento de soldagem entre partículas. Considerando a moagem de uma mistura, na segunda fase (II) ocorre a formação de partículas compostas, denominadas de agregados, com uma distribuição simples dos materiais que constituem a mistura e com composição química 
heterogênea. Com o acúmulo de deformação plástica há um aumento do encruamento e da resistência mecânica das partículas. Essa situação aumenta a probabilidade de fratura das partículas ou agregados. Na terceira fase (III) o equilíbrio entre os processos de fratura e de soldagem modifica a dispersão dos materiais da mistura nos agregados, homogeneizando-os quimicamente. A última fase (IV) é caracterizada pelo refinamento da microestrutura desses agregados.

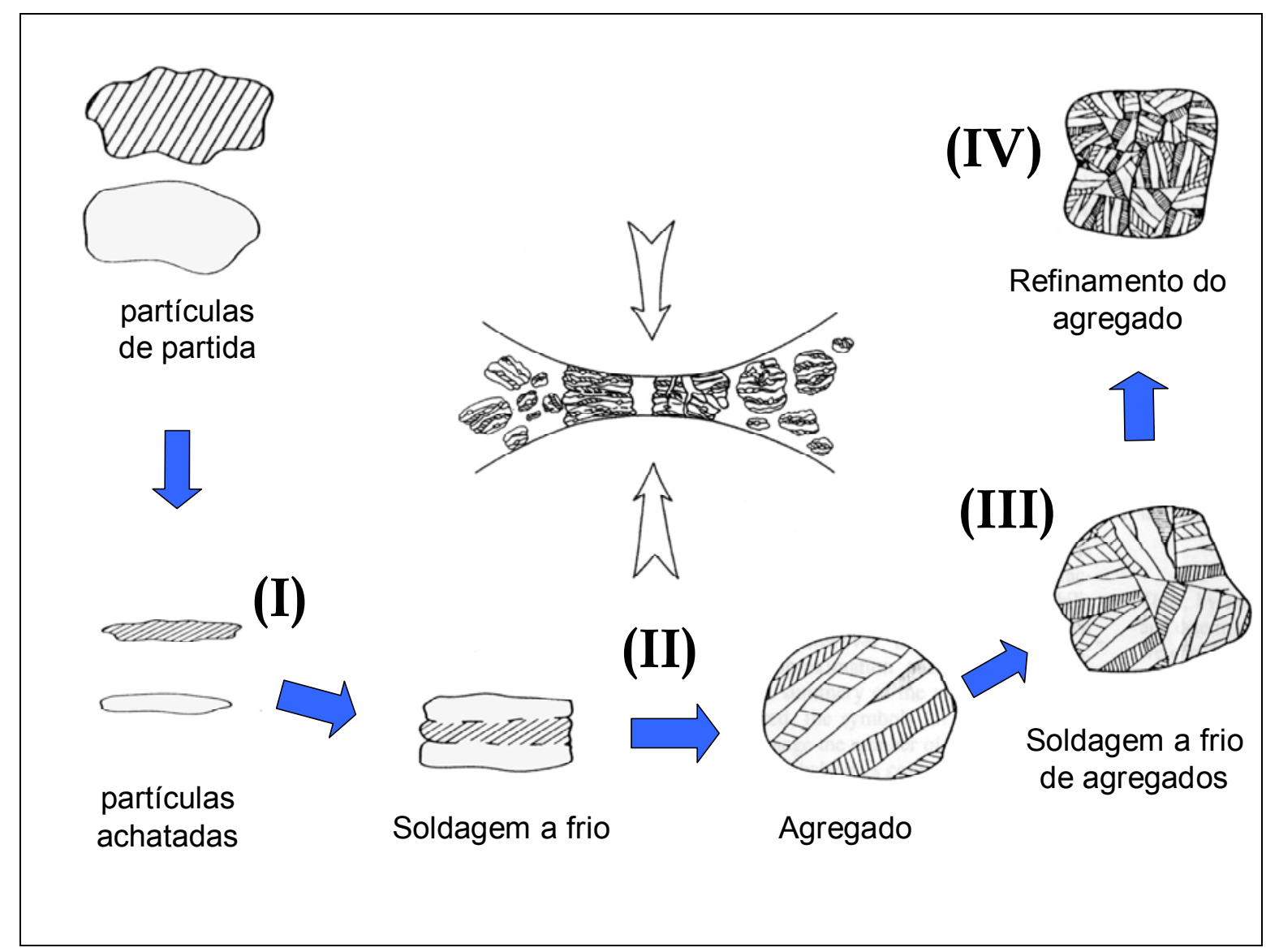

FIGURA 1 - Esquema das fases do processo de moagem de misturas de pós dúcteis $^{[17]}$.

\subsubsection{Ativação mecânica}

Quando o processamento mecânico modifica as características do material em relação à sua reatividade reduzindo a energia de ativação para iniciar uma reação química, emprega-se o termo "ativação mecânica" ${ }^{[18,19]}$, o qual foi utilizado pela primeira vez para designar a otimização de reações entre compostos orgânicos e metais a partir de materiais obtidos durante processos de usinagem $^{[20]}$. 
As características físicas e químicas dos componentes de um sistema particulado mono ou polifásico são de fundamental importância na extensão dos efeitos da ativação mecânica. Sistemas frágeis têm limitada capacidade de deformação plástica, o que induz à fratura das partículas, aumentando a área de superfície específica. Em materiais iônicos e covalentes esse aumento da área de superfície é acompanhado de um aumento das tensões elásticas e de defeitos estruturais e eletrônicos, alterando a reatividade e a energia interna ${ }^{[21]}$. Sistemas dúcteis têm a densidade de defeitos cristalinos aumentada em virtude da deformação plástica intensa. A redução do tamanho de partícula é menos acentuada que em sistemas frágeis, porém é possível obter acentuadas reduções no tamanho de cristalito, formando materiais nanocristalinos que possuem propriedades químicas, físicas e mecânicas diferenciadas ${ }^{[22]}$.

Durante a moagem de alta energia pode ocorrer a síntese de materiais por combustão $^{[23]}$ ou pelo refino contínuo da microestrutura de agregados dos componentes da mistura ${ }^{[24]}$.

\subsubsection{Tipos de moinhos de bolas}

Diferentes tipos de equipamentos podem ser utilizados na moagem de materiais particulados. Eles diferem-se na capacidade, na eficiência de moagem e nos dispositivos adicionais para aquecimento ou resfriamento. Os moinhos mais comuns em laboratórios são os agitadores, os planetários, os atritores e os convencionais.

\subsubsection{Moinhos agitadores ("shaker mill")}

Esses moinhos são fabricados pela SPEX® CertPrep (Metuchen - NJ - EUA) e são muito conhecidos pelo nome do fabricante. Podem moer entre 10 e $20 \mathrm{~g}$ de pó de cada vez, e são mais comumente usados em laboratórios de pesquisa. A variedade mais comum consiste de uma biela em cuja extremidade se prende o copo com as bolas de moagem. A biela sacode o copo vigorosamente milhares de vezes por minuto, e este deslocamento é acompanhado de movimentos laterais e cíclicos da biela. A cada ciclo, as bolas se chocam entre si e com as paredes do copo, o que acarreta não só moagem, mas também mistura (FIG. 2 A). Em virtude da amplitude $(\sim 5 \mathrm{~cm})$ e da velocidade do copo durante a moagem ( 1200 rpm), a 
velocidade das bolas é alta, da ordem de $5 \mathrm{~m} / \mathrm{s}$ e conseqüentemente a força do impacto das mesmas é muito elevada. Portanto, estes moinhos podem ser considerados de alta energia ${ }^{[15]}$.

\subsubsection{Moinhos do tipo planetário}

Outro moinho de utilização bastante difundida em experimentos de laboratório é o planetário (FIG. 2 B), no qual algumas centenas de gramas de pó podem ser moídas de uma só vez. Um dos fabricantes mais conhecidos é a Fritsch $\mathrm{GmbH}$ (Alemanha) e seus modelos Pulverisette. Os moinhos planetários possuem esse nome em virtude dos movimentos de rotação e translação dos recipientes de moagem, semelhantes aos de um sistema planetário. Os recipientes de moagem são montados e arranjados sobre um disco suporte móvel que, graças a um mecanismo especial, faz que girem em torno de seu próprio eixo. A força centrífuga produzida pelos recipientes girando em torno de seu próprio eixo aliada à força gerada pela rotação do disco suporte atuam na carga contida nos recipientes (material a ser moído e bolas). Visto que os recipientes e o disco suporte giram em sentidos opostos, as forças centrífugas atuam alternadamente em direções opostas. Isto faz que as bolas de moagem se choquem alternadamente entre as extremidades dos recipientes, causando o efeito de impacto. Apesar da maior velocidade linear das bolas neste tipo de moinho em relação aos moinhos $S P E X ®$, a freqüência dos impactos é muito maior nestes últimos. Assim, em comparação com os moinhos agitadores, o planetário pode ser considerado um moinho de média energia ${ }^{[15]}$.

\subsubsection{Moinhos atritores}

Atritores são moinhos em que podem ser processadas grandes quantidades de pó $(0,5 \sim 40 \mathrm{~kg})$ de cada vez. A velocidade do meio de moagem $(\sim 0,5 \mathrm{~m} / \mathrm{s})$ é bem inferior à do agitador e à do planetário e, conseqüentemente, a energia dos atritores é menor. Atritores de diversos tamanhos e capacidades estão disponíveis com uma variedade de meios de moagem (vidro, cerâmica, mulita, carbeto de silício, sialon, alumina, zircônio, aço inoxidável, aço carbono, aço cromo, carbeto de tungstênio e outros).

Um moinho atritor consiste de um tambor fixo vertical, com uma série de 
impulsionadores das bolas em seu interior, dispostos sucessivamente, formando ângulos retos uns com os outros (FIG. 2 C). O funcionamento de um atritor é simples. O pó a ser moído é depositado num tanque estacionário com a mídia de moagem. A mistura é então agitada pela hélice com os impulsores, girando a altas velocidades ( $250 \mathrm{rpm}$ ). Isto faz que o meio de moagem exerça forças de cisalhamento e impacto no material. Um atritor de laboratório trabalha até 10 vezes mais rápido que um moinho convencional ${ }^{[15]}$.

\subsubsection{Moinhos convencionais (jarra)}

Um típico de moinho de jarra consiste de um recipiente cilíndrico horizontal, contendo bolas e o material a ser moído. À medida que a jarra é rotacionada, as bolas colidem com o material a ser moído, em razão da queda livre que sofrem no seu interior (FIG.2 D). A velocidade de rotação da jarra é ajustada para produzir a queda das bolas do topo, o que maximiza sua velocidade de impacto. Se a velocidade for muito lenta, não haverá impulso suficiente para conduzir as bolas ao topo de jarra, e elas poderão rolar de volta à base. Uma velocidade muito alta impedirá a queda das bolas devido à força centrífuga ${ }^{[15]}$.

(A)

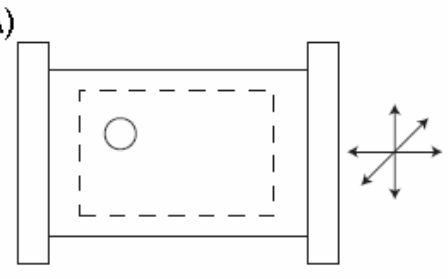

(C)

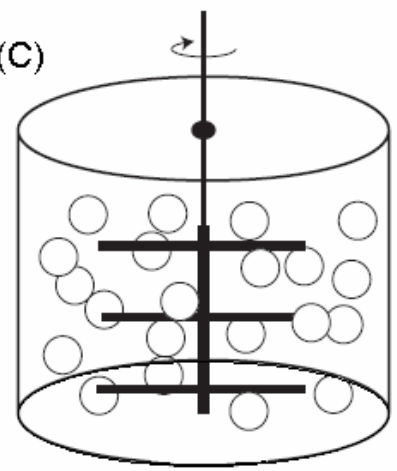

(B)

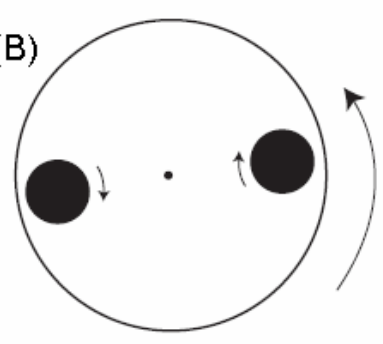

(D)

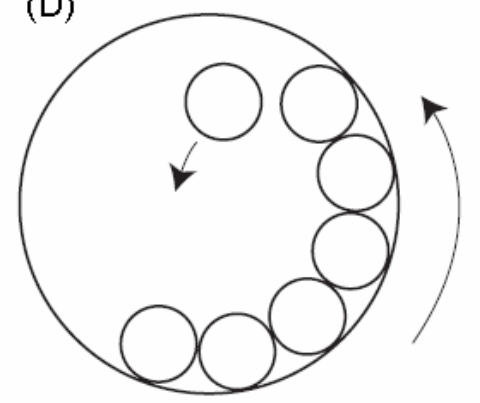

FIGURA 2- Esquema de um moinho agitador $(A)$, planetário $(B)$, atritor $(C)$ e moinho convencional (D). 


\subsubsection{Recipiente e bolas de moagem}

O material usado na confecção do recipiente de moagem (copo, tambor, jarra) é importante, visto que o impacto entre as bolas de moagem e as paredes do recipiente pode ocasionar desgaste e incorporação de material ao pó. Se o material das bolas de moagem for diferente do material do pó, pode haver contaminação do pó com o material das bolas. Se ambos os materiais forem os mesmos, pode haver aumento da massa de pó ou alteração da composição química, no caso de mistura de pós. Aços carbono e aços ligados (aços ferramenta; aços inoxidáveis), bem como metal duro ${ }^{[25]}$, são os tipos mais comuns de materiais utilizados em bolas de moagem.

A forma do recipiente também tem importância, especialmente o projeto de seu interior. Copos com extremidades arredondadas internamente e copos com extremidades planas foram utilizados num moinho SPEX®, e as taxas de ativação obtidas com estes últimos foram maiores ${ }^{[26]}$.

A massa das bolas de moagem também tem influencia na eficiência da moagem. Quanto maior o tamanho e quanto maior a densidade, maior será a energia cinética das bolas. Bolas maiores ou mais densas são mais pesadas e transferem maior energia de impacto às partículas de pó, o que interfere também na constituição final do pó ${ }^{[27]}$. É sugerido que bolas menores produzem maior ação da fricção, a qual promove a formação de fases amorfas ou metaestáveis $^{[28,29]}$.

Embora a maioria dos pesquisadores utilize bolas de mesmo tamanho, é reportado que, com bolas de tamanhos diferentes, a soldagem a frio diminui de intensidade, bem como a aderência da camada de pó às bolas ${ }^{[15]}$.

\subsubsection{Variáveis de processo}

\subsubsection{Velocidade de moagem}

Quanto maior a velocidade das bolas de moagem, maior será sua energia cinética e, consequentemente, menor o tempo de moagem, desde que haja colisão entre as bolas de moagem e o pó. O modo como a velocidade das bolas é alterada depende do tipo de moinho empregado.

Em um moinho de bolas convencional a velocidade de queda das bolas é alterada pelo diâmetro do recipiente (maior diâmetro, maior altura de queda). Nos 
demais moinhos citados anteriormente, a velocidade das bolas é função da rotação ou freqüência de movimentação de seus recipientes (moinhos agitadores e planetários) ou de seus impulsionadores (moinhos atritores).

O aumento da velocidade das bolas implica em aumento da temperatura dos recipientes. Este fato pode ser vantajoso em casos onde a difusão é requerida para promover a homogeneização e a elaboração de ligas, mas, em outros casos, pode acelerar os processos de transformação e resultar na decomposição de soluções sólidas supersaturadas ${ }^{[30]}$ ou outras fases metaestáveis formadas durante o processo de moagem ${ }^{[31]}$.

\subsubsection{Tempo de moagem}

O tempo de moagem geralmente é escolhido de forma a se conseguir o equilíbrio entre a fratura e a soldagem a frio das partículas de pó. O tempo de moagem depende do tipo de material a ser moído, do tipo de moinho, da intensidade (energia) da moagem, da razão bola-pó e da temperatura. O tempo deve ser escolhido levando-se em conta a combinação dos parâmetros mencionados anteriormente, e tendo conhecimento de que tempos maiores que o necessário aumentam a contaminação e a formação de algumas fases indesejáveis (contaminantes) ${ }^{[32]}$.

\subsubsection{Razão bola-pó}

A razão bola-pó (RBP) é a proporção ou relação entre a massa das bolas de moagem e a massa de pó. Pesquisadores variaram este valor entre $1: 1^{[33]} \mathrm{e}$ $220: 1^{[34]}$. Geralmente, uma razão de $10: 1$ é mais utilizada quando a moagem de pequenas quantidades de pó é feita no moinho SPEX®. Na moagem de maiores quantidades de carga, como num atritor, razões maiores são requeridas (50:1 ou mesmo 100:1).

A razão bola-pó (às vezes denominada razão de carga) afeta diretamente o tempo para se moer, ou seja, diminuir o tamanho das partículas do pó. A RBP é particularmente importante quando se deseja obter uma determinada fase no pó sendo moído. Em outras palavras, quanto maior a RBP, menor é o tempo requerido $^{[35]}$. 


\subsubsection{Quantidade de pó}

Visto que a moagem ou a elaboração mecânica de ligas ocorrem em virtude da força de impacto das bolas de moagem no pó, é necessário que haja suficiente espaço para que tanto as bolas como o pó se movimentem livremente dentro do recipiente. Geralmente, $50 \%$ do copo é ocupado pelo volume de pó junto com o meio (bolas) de moagem ${ }^{[15]}$.

\subsubsection{Agente controlador de processo- ACP}

As partículas de pó soldam-se umas às outras a frio, especialmente se os materiais forem dúcteis, devido à elevada deformação plástica sofrida durante a moagem. No caso de elaboração mecânica de ligas deverá haver um equilíbrio entre a soldagem a frio e a fratura entre as partículas. O agente controlador de processo (também denominado lubrificante ou surfactante) é adicionado às misturas de pós durante a moagem para reduzir a soldagem a frio. Os ACPs podem ser sólidos, líquidos ou gasosos. Eles são, na sua maioria, mas não necessariamente, compostos orgânicos. São adsorvidos nas partículas de pó reduzindo a tensão superficial, minimizando a soldagem a frio $e$, conseqüentemente, reduzindo a agregação das partículas. Os ACPs mais utilizados são o ácido esteárico, o hexano, o etanol e o metanol ${ }^{[15]}$.

O tipo e a quantidade de ACP utilizado também tem conseqüências no tamanho, forma e pureza final das partículas. O uso de quantidades grandes de ACP normalmente implica em maior redução do tamanho de partícula. Há relatos que a moagem do alumínio por $5 \mathrm{~h}$ com $1 \%$ em peso de ácido esteárico produz um tamanho médio de partícula de $500 \mu \mathrm{m}$, ao passo que com o mesmo tempo de moagem e utilizando-se $3 \%$ de ácido esteárico em peso, o tamanho é de $10 \mu \mathrm{m}^{[29]}$.

Para a moagem de materiais frágeis, no entanto, o uso de ACP não é requerido, obtendo-se um tamanho homogêneo de partículas quando da moagem destes materiais.

Em resumo, é necessário compreender que não há um ACP universal, ou seja, para cada situação existe um determinado ACP mais indicado. A quantidade de ACP a ser utilizada depende do grau de soldagem a frio do pó, da estabilidade química e térmica do ACP e da quantidade de pó e do meio de moagem utilizado. 
O tamanho de partícula do pó tende a aumentar se o ACP é utilizado abaixo de certo valor crítico, ao passo que acima deste valor, o tamanho tende a decrescer.

\subsection{Síntese por combustão mecanicamente ativada}

Síntese por combustão é uma técnica baseada no conceito de que reações exotérmicas, uma vez atingida a temperatura de ignição localmente ou na mistura como um todo por meio de uma fonte de calor externa, podem se tornar autosustentaveis com propagação na forma de uma onda de combustão e podem formar o produto final progressivamente sem requerer calor adicional.

A influência da ativação mecânica no comportamento térmico de misturas reagidas por combustão tem sido reportada em vários trabalhos ${ }^{[36-40]}$. Gauthier et.al. ${ }^{[36]}$, realizando uma variação do processo SHS denominado MASHS (mechanically activated SHS), constataram uma diminuição da temperatura de

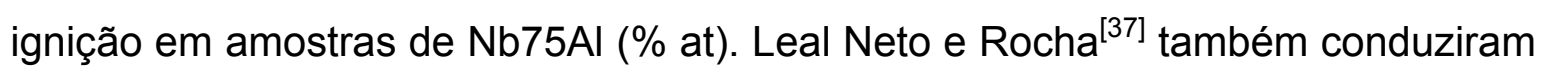
uma investigação no mesmo composto, processado em diferentes tempos de moagem (uma, duas e três horas) e reagido posteriormente por combustão simultânea. A partir da análise térmica, constatou-se também uma diminuição na temperatura de ignição (em alguns casos abaixo da temperatura de fusão do alumínio) das misturas mecanicamente ativadas. Tal fenômeno pode ser explicado por um aumento na cinética da reação, em razão de um maior contato entre as partículas de pós reagentes, promovido pela ação da moagem. A obtenção de materiais com estrutura altamente refinada e com um elevado grau de dispersão é possível em virtude do mecanismo de moagem explicado anteriormente, o qual é caracterizado por eventos sucessivos de deformação, fratura, criação de novas superfícies e soldagem entre as partículas de pós ${ }^{[16]}$. Para tal finalidade, um equilíbrio entre os eventos de fratura e soldagem deve ser mantido. Na moagem de pós metálicos dúcteis, como o alumínio, observou-se que esse equilíbrio não ocorre naturalmente, em razão da elevada deformação plástica sofrida pelo mesmo ${ }^{[29]}$. Dessa forma, o mecanismo e o rendimento da moagem são prejudicados, ocorrendo uma excessiva soldagem entre as partículas de pós, bem como uma elevada aderência nas bolas e nas paredes do recipiente de moagem. Dentre as alternativas utilizadas para minimizar esses efeitos e garantir uma eficiente ação de moagem, encontram-se a diminuição da temperatura (moagem 
criogênica) e a adição de ACPs em pequenas quantidades. Dentre esses dois procedimentos, verifica-se que o uso de lubrificantes é mais comum ${ }^{[29]}$.

\subsection{Compressibilidade e compactação de pós}

Segundo Schwartzkopf ${ }^{[41]}$, o termo compressibilidade deve ser usado para indicar o grau de aumento da densidade de uma certa massa de pó ao se aplicar uma certa pressão, ao passo que a "compactabilidade" é definida como a pressão mínima necessária para produzir um compacto com certa resistência a verde. Em termodinâmica, é a medida da mudança relativa de volume (de um fluido ou sólido) em resposta à variação de pressão ou tensão. Em termos gerais, a compressibilidade de pós pode ser definida como a facilidade com que as partículas poderão ser compactadas quando submetidas à pressão num espaço restrito. É a compressibilidade que em grande parte determinará a pressão de compactação que deverá ser empregada para se atingir determinada densidade no compactado. Normalmente utilizam-se curvas densidade $x$ pressão ou, alternativamente, carga (à qual o compacto é submetido) x deslocamento (do travessão ou pistão do equipamento de compactação) que, para a compactação uniaxial, podem ser relacionados com a pressão e a densidade (área e massa constantes) respectivamente.

A consolidação de um pó metálico começa com a transferência e o preenchimento do molde ou matriz pelo pó. Nesta estapa, a distribuição da densidade do pó não compactado depende não só da natureza das partículas mas também dos métodos de preenchimento e transferência do pó na matriz/molde ${ }^{[42]}$. Após o preenchimento da matriz comprime-se o pó para a obtenção de um agregado metálico. Esta etapa foi descrita por Seelig e Wulff ${ }^{[43]}$ que definem três estágios durante a compactação. No primeiro, que corresponde aos mais baixos esforços aplicados, as partículas se rearranjam. No segundo, produz-se a deformação elasto-plástica das partículas junto às suas áreas de contato. Estes dois estágios podem acontecer simultaneamente desde o começo da compactação ${ }^{[44]}$. O último estagio, sob esforços elevados, é caracterizado pela deformação plástica e encruamento das partículas, com ou sem fragmentação.

A compactação de pós metálicos envolve transmissão de tensões via paredes (rígidas ou flexíveis) da matriz e a propagação dessas tensões através 
da massa de pó. As partículas que compõem o pó distribuem as tensões por uma série de processos cinemáticos que envolvem movimentação, escorregamento, rotação, deformação e ruptura das partículas ${ }^{[45]}$. Os modelos de processos de compactação são analisados mais adiante, no item 3.5.3.

A compactação é influenciada por uma série de fatores extrínsecos (relativos ao modo e ao ferramental de compactação) e intrínsecos (relativos às características do material sendo compactado). Dentre os vários fatores extrínsecos pertinentes, como tipo de prensa, de matriz, ação da compactação (uniaxial, biaxial, isostática), os únicos que serão abordados serão a lubrificação das paredes da matriz e a velocidade de compactação.

Quanto aos fatores intrínsecos, serão abordados o tamanho, forma e área de superfície específica das partículas; o encruamento e dureza das partículas e a quantidade e tipo de ACP.

\subsubsection{Fatores extrínsecos}

\subsubsection{Lubrificação}

Os lubrificantes são aplicados nas paredes da matriz de compactação com o intuito de favorecer a ejeção do compactado e minimizar o desgaste do ferramental ${ }^{[46]}$., bem como reduzir a fricção interfacial. Esta última tem um papel importante na compactação de materiais particulados, pois dela resulta a formação de gradientes de densidade no compactado que, caso elevados, poderão comprometer propriedades mecânicas e tolerâncias dimensionais no produto final. Muitas vezes o lubrificante é adicionado ao pó, mas isto não será considerado aqui como fator extrínseco e sim intrínseco à mistura (o agente controlador de processo adicionado à mistura durante a ativação mecânica será um fator sujeito à investigação). Por modificar o atrito do pó com as paredes da matriz, o tipo de lubrificante e também a maneira com que tal lubrificante é aplicado às paredes são fatores que precisam ser rigorosamente observados e controlados quando se quer obter resultados precisos (alta reprodutibilidade). Na compactação, a fricção não pode ser eliminada, mas seus efeitos podem ser minimizados de algumas formas, além do uso de lubrificantes, quais sejam: a) compactando-se peças com uma razão altura / diâmetro baixa; b) utilizandose compactação biaxial; c) compactando-se pós com elevada concentração de água ${ }^{[47] ;}$ como no caso da bentonita; d) empregando-se matriz flutuante. 


\subsubsection{Velocidade de compactação}

As partículas de pó, quando submetidas à pressão, são inicialmente rearranjadas antes que se inicie a deformação plástica (encruamento) ou fratura $^{[48]}$. Assim, velocidades de compactação muito altas são prejudiciais à densificação durante a compactação, pois o tempo para que ocorram estes fenômenos é reduzido, podendo haver diferenças nas densidades finais dos compactados a uma mesma pressão com diferentes velocidades.

\subsubsection{Fatores intrínsecos}

\subsubsection{Tamanho, forma e área de superfície específica das partículas}

Partículas menores, irregulares e com maior área de superfície específica (área total da superfície por unidade de massa ou volume) têm maior atrito e menor densidade aparente (massa média das partículas por volume, na sua apresentação habitual ou para determinado lote). Partículas maiores tendem a ter densidade aparente maior, e entre diferentes tamanhos de partícula de mesmos materiais há também diferenças nas curvas de compressibilidade.

\subsubsection{Encruamento e dureza das partículas}

Em geral, partículas de materiais mais duros ou muito encruadas (por exemplo, por processos de ativação mecânica prévia, como os que serão investigados neste trabalho) implicam menor compressibilidade da massa de pó, pois a deformação plástica é reduzida.

\subsubsection{Quantidade e tipo de ACP}

Afetam a lubrificação das partículas e, portanto, o atrito entre elas, modificando profundamente a compressibilidade e outros parâmetros (vide item 3.5.1.1).

\subsubsection{Modelos de compactação}

Os modelos matemáticos para descrever os processos de compactação de pós têm avançado bastante com a disponibilidade de computadores poderosos e seus periféricos, bem como a utilização de softwares apropriados. Os modelos de 
compactação podem fornecer uma base para as especificações de carregamento das máquinas, minimização de defeitos e predição da heterogeneidade da distribuição de tensões em compactados a verde; podem igualmente predizer características microestruturais internas durante a sinterização, como tamanho de grão, porosidade e a forma externa do produto sinterizado final.

Há várias categorias de modelos de compactação: os modelos de primeira ordem, os modelos de elementos finitos, os modelos discretos ou distintos, e o modelo de elementos de contorno ${ }^{[45]}$. Os modelos de primeira ordem são mais simples e essenciais, e por isso serão os investigados neste trabalho.

De acordo com Balshin ${ }^{[49]}$, a pressão imposta ao compacto afeta o seu volume relativo de acordo com a seguinte relação:

$$
\text { In } P=-A_{1} V+B_{1}
$$

Em que:

P é a pressão aplicada, $V$ é o volume relativo (ou seja, razão do volume específico do compacto com o do material sem porosidade), e $A_{1}$ e $B_{1}$ são constantes empíricas. $A_{1}$ seria análoga ao módulo de Young e $B_{1}$ é determinada pelo intercepto da curva de $\ln \mathrm{P} \times \mathrm{V}$. Para efeito de comparação com as próximas equações, (que são descritas em termos de densidade relativa e volume), a equação de Balshin pode ser reescrita como:

$$
\ln P=-\frac{A_{2}}{D}+B_{2}
$$

Em que $P$ é a pressão aplicada, $D$ é a densidade relativa, $A_{2}$ e $B_{2}$ são constantes.

Heckel, em 1961 ${ }^{[50]}$, considerou que a compactação de pós era análoga a uma reação química de primeira ordem. Os poros seriam os reagentes e a densificação do compacto o produto. A "cinética" do processo pode ser descrita como a proporcionalidade entre a mudança da densidade com a pressão e a fração de poros (eq. 3) por:

$$
\frac{\partial D}{\partial P}=K(1-D)
$$


em que $D$ é a densidade relativa do compacto, $P$ é a pressão aplicada, (1-D) é a fração de poros e K é uma constante. A forma final da equação de Heckel (eq. 4) pode ser escrita como:

$$
\ln \left(\frac{1}{1-D}\right)=A_{3} P+B_{3}
$$

onde $A_{3}$ e $B_{3}$ são constantes.

Heckel postulou que a constante $A_{3}$ é a medida da capacidade do compacto densificar-se pela deformação plástica e a constante $B_{3}$ representa 0 grau de empacotamento a baixas pressões (resultado do rearranjo antes que quantidade considerável de soldagem inter-partículas tenha ocorrido).

Kawakita e Lüdde $^{[51]}$ derivaram a equação de compactação da relação observada entre a pressão aplicada e o volume baseados na relação linear entre $\mathrm{P} / \mathrm{C}$ e $\mathrm{P}$, que permite uma avaliação gráfica das constantes, obtendo a seguinte equação (5):

$$
\frac{\mathrm{P}}{\mathrm{C}}=\frac{1}{\mathrm{ab}}+\frac{\mathrm{P}}{\mathrm{a}} \text { com } \mathrm{C}=\frac{\mathrm{V}_{0}-\mathrm{V}}{\mathrm{V}_{0}}
$$

em que $P$ é a pressão aplicada, $A_{4}$ e $B_{4}$ são constantes $\left(A_{4}=1 / a\right.$ e $\left.B_{4}=1 / a b\right), V_{0}$ é o volume do pó na ausência de pressão e $V$ é o volume do pó à pressão $P$.

Esta é a forma original da equação de Kawakita. Muitos autores transformam os volumes em densidades, resultando na equação (6):

$$
\frac{D}{D-D_{0}}=\frac{A_{5}}{P}+B_{5}
$$

em que $D$ é a densidade relativa do compacto, $D_{0}$ é a densidade relativa aparente do pó sem a aplicação de pressão e $A_{5}$ e $B_{5}$ são constantes.

$G e^{[52]}$, baseado em vários sets de dados publicados sobre compactação de pós metálicos e não-metálicos, propôs a seguinte equação (7): 


$$
\log \left(\ln \frac{1}{(1-D)}\right)=A_{6} \log P+B_{6}
$$

$A_{6}$ e $B_{6}$ são constantes, e $D$ é a densidade relativa do compacto à pressão $P$.

Panelli e Ambrozio Filho ${ }^{[53]}$ propuseram mais uma equação (8):

$$
\ln \left(\frac{1}{1-D}\right)=A_{7} \sqrt{P}+B_{7}
$$

em que $A_{7}$ e $B_{7}$ são constantes e podem ser utilizadas como parâmetros de caracterização do comportamento do pó durante a compactação. Esta última equação tem formato similar à equação de Heckel.

Em todas as equações os parâmetros A podem ser usados para mostrar a capacidade que o pó tem de se densificar por deformação plástica, e correspondem à inclinação das curvas de compressibilidade. Os parâmetros $B$ podem ser utilizados para calcular a densidade relativa do pó à pressão zero $\left(D_{0}\right)$ e correspondem à intersecção da curva de compressibilidade com o eixo das ordenadas.

No entanto, no início da compactação o rearranjo deve ser levado em conta, motivo pelo qual $0 D_{0}$ calculado utilizando o parâmetro $B$ poderá ser diferente da densidade relativa do pó solto $\left(D_{a p}\right)$ determinada pela ASTM B212 $99(2006)^{[57]}$ ou equivalente (normas de ensaio que descrevem o procedimento para determinar a densidade aparente solta de pós metálicos usando o funil de Hall). 


\section{MATERIAIS E MÉTODOS}

Testes preliminares foram realizados com o objetivo de elaborar um procedimento padrão a ser adotado no ensaio de compressibilidade e também de possibilitar uma familiarização com o ferramental empregado. Nesta fase foram ensaiados pós de níquel e alumínio de pureza comercial.

$\mathrm{Na}$ definição dos procedimentos citam-se a metodologia de utilização dos dispositivos de compactação no sentido de identificar e descontar eventuais folgas, a determinação da rigidez do sistema, as cargas a serem aplicadas e a velocidade de compactação.

Uma vez definido o procedimento, foram ensaiadas amostras de misturas de $\mathrm{Nb}$ e $\mathrm{Al}$ ativadas mecanicamente. Foram feitas moagens com misturas de diferentes pós variando-se o tempo de ativação mecânica e o ACP. Todos os pós e a grande maioria das misturas obtidas foram caracterizados por microscopia eletrônica de varredura (MEV).

Aos dados de compressibilidade obtidos foram ajustadas algumas equações de compactação publicadas na literatura para fins de comparação e análise do melhor ajuste.

\subsection{Ensaios de compressibilidade: definição do procedimento}

Para a compactação foi utilizada uma máquina universal de ensaios, marca INSTRON, modelo 4400R, eletro-mecânica, com capacidade máxima de 10 toneladas, aplicação uniaxial de carga, acionamento do travessão por dois parafusos sem-fim e operada por software INSTRON Series IX.

O ferramental de compactação usado constituiu-se de dois punções (superior e inferior) e matriz de geometria cilíndrica, com diâmetro interno de 14 $\mathrm{mm}$, externo de $70 \mathrm{~mm}$ e altura de $96 \mathrm{~mm}$, fabricados em aço AISI D6.

\subsubsection{Determinação da rigidez do sistema (testes em vazio)}

Esta quantificação é importante, pois das curvas de compressibilidade é necessário descontar folgas e a deformação elástica inerentes ao sistema (máquina de ensaio e ferramental de compactação) para se obter dados exclusivos das amostras ensaiadas. Para se avaliar a rigidez do sistema (máquina 
de ensaio e matriz) foram realizados testes em vazio de compressão (sem pó no interior da matriz), usando-se estearato de zinco em pó como lubrificante nas paredes da matriz e punções. A carga empregada foi de 6,0 toneladas-força com velocidade de deslocamento do travessão de $1 \mathrm{~mm} / \mathrm{min}$, com aquisição pelo software de um ponto de leitura a cada $0,3 \mathrm{~s}$. O gráfico obtido foi do tipo deslocamento x carga (FIG. 3), com base no qual foi possível quantificar as folgas e a deformação elástica do sistema.

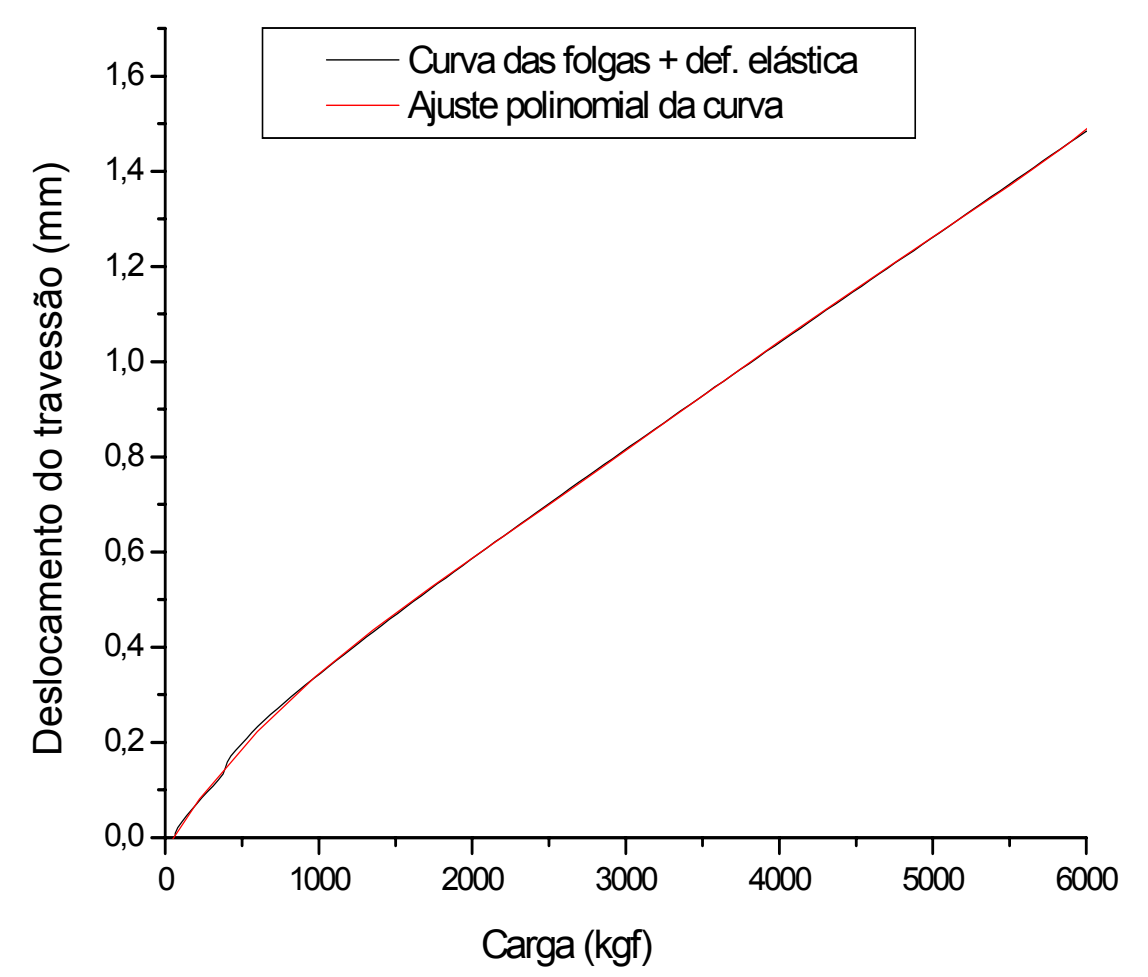

FIGURA 3 - Deslocamento do travessão (teste em vazio) x carga de compressão e ajuste polinomial da curva obtida.

A equação obtida para a compactação em vazio, denominada de "equação de correção" foi obtida a partir de regressões polinomiais sucessivas (121 pontos de leitura), por meio do software Origin ${ }^{\circledR} 6.1$. A equação que melhor representou a curva da rigidez do sistema mais as folgas (equação 9) é um polinômio de $5^{\circ} \mathrm{grau}$, com coeficiente de correlação polinomial $\left(R^{2}\right)$ muito próximo à unidade, conforme a seguir:

$$
Y=A+B 1^{*} X+B 2^{*} X^{2}+B 3^{*} X^{3}+B 4^{*} X^{4}+B 5^{*} X^{5}
$$


Os valores dos coeficientes da equação e da correlação do ajuste são apresentados na TAB. 1.

Tabela 1- Coeficientes da equação de calibração e $R^{2}$ para 121 pontos de leitura

\begin{tabular}{clll} 
Parâmetro & Valor & Erro & Observações \\
\hline A & $-0,02134$ & 0,0018 & \\
B1 & $4,97205 \mathrm{E}-4$ & $6,52415 \mathrm{E}-6$ & \\
B2 & $-1,79765 \mathrm{E}-7$ & $6,86815 \mathrm{E}-9$ & \\
B3 & $5,66122 \mathrm{E}-11$ & $2,92035 \mathrm{E}-12$ & \\
B4 & $-8,44172 \mathrm{E}-15$ & $5,36694 \mathrm{E}-16$ & \\
B5 & $4,76935 \mathrm{E}-19$ & $3,54851 \mathrm{E}-20$ & \\
$\mathrm{R}^{2}$ & 0,99993 & $0,00387{ }^{*}$ & $\mathrm{P}<0,0001^{* *}$ \\
\hline \multicolumn{4}{c}{${ }^{*}$ Desvio padrão do ajuste; ${ }^{* *} \mathrm{P}=$ probabilidade de $\mathrm{R}^{2}$ ser zero }
\end{tabular}

\subsubsection{Compactação de pós - correção das curvas de compressibilidade}

O material utilizado nesta fase de definição de procedimento foi um pó de níquel, fornecido pela Combustol, proveniente da decomposição térmica de carbonilas. A razão para o emprego deste pó foi o fato de que há um considerável estoque deste material no laboratório de intermetálicos, além de poupar os pós de alumínio e nióbio, cujos estoques são menores, utilizados para outras investigações.

O lubrificante utilizado nas paredes internas da matriz e nos punções, para diminuir o atrito, evitar o desgaste do ferramental e facilitar a ejeção do compactado, foi estearato de zinco em pó. Para sua aplicação foi utilizado um pincel macio, sendo o excesso removido por meio do deslocamento de ar promovido por um abano.

A massa estipulada para todos os ensaios de compactação (preliminares e amostras moídas) foi de $4 \mathrm{~g}$.

Nas compactações com volume de pó diferente de zero (ou seja, nas compactações das amostras de pó) adotou-se uma carga máxima de 6 toneladasforça ou pressão de $400 \mathrm{MPa}$ (no caso da matriz utilizada neste trabalho) por razões de segurança, especialmente no tocante à flambagem dos punções, uma vez que o limite de escoamento à tração do aço AISI D6, do qual a matriz e os 
punções são feitos, é de aproximadamente $515 \mathrm{MPa}$. A velocidade de deslocamento do travessão foi de $1 \mathrm{~mm} / \mathrm{min}$.

O deslocamento referente às folgas e à deformação elástica do sistema foi subtraído do deslocamento correspondente na compactação dos pós nas mesmas cargas, para obtenção da curva corrigida, conforme ilustrado na FIG. 4 (pó de níquel). Este cálculo foi feito aplicando-se os valores referentes a cada ponto de carga da amostra nos valores $Y$ (também referentes à carga) da equação 9.

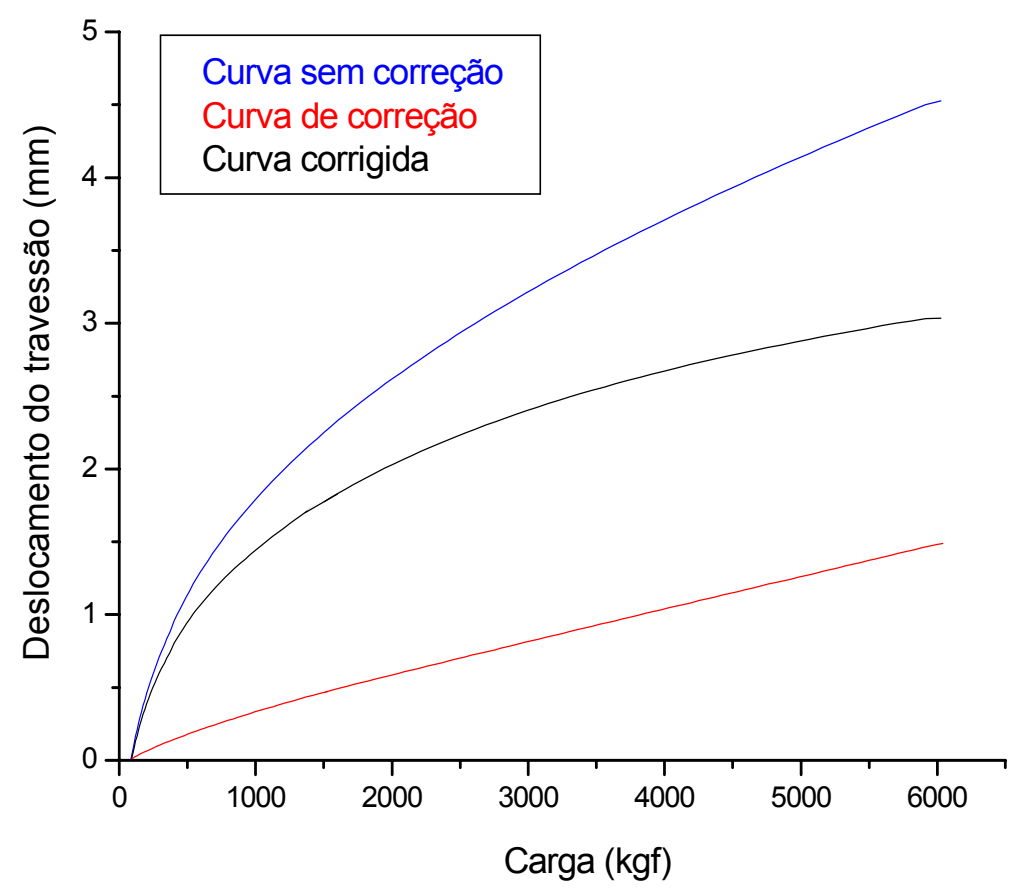

FIGURA 4 - Curvas de correção do sistema (vermelha), de compactação da amostra sem correção (azul) e de compactação da amostra corrigida (preta)

\subsubsection{Compactação de pós - variação do apoio da matriz}

Foram realizados também testes variando-se o apoio da matriz, a saber:

- Apoio em bloco de espuma durante todo o ensaio (matriz flutuante);

- Apoio em suporte rígido (neste caso o próprio extrator da matriz) durante todo o ensaio (matriz fixa);

- Apoio sobre o extrator até carga de $30 \mathrm{kgf}$ e retirada do apoio (matriz flutuante). 
Na FIG. 5 são apresentadas as curvas referentes aos três tipos de apoio da matriz na compactação de pós de níquel. A curva preta é o resultado da compactação da amostra Ni ESP (apoio em bloco de espuma), e está praticamente sobreposta à curva da amostra Ni EXT2 (apoio no extrator até $30 \mathrm{kgf}$ ). A curva vermelha (Ni EXT1) refere-se à compactação com a matriz apoiada no extrator durante todo o ensaio, diferindo-se ligeiramente das outras duas curvas. Em razão da semelhança de resultados das curvas de compactação com matriz flutuante, e levando-se em conta a melhor distribuição de pressão que existe nessa condição, optou-se pela condição de apoio da matriz no extrator até $30 \mathrm{kgf}$, por uma questão de repetibilidade (com a colocação da espuma no lugar do extrator fica comprometida a garantia de que o pó esteja sempre na mesma posição relativa inicial dentro da matriz). Como esta pré-carga é aplicada ajustando-se o travessão sem o controle pelo software, há flutuações que podem chegar a até 70 kgf.

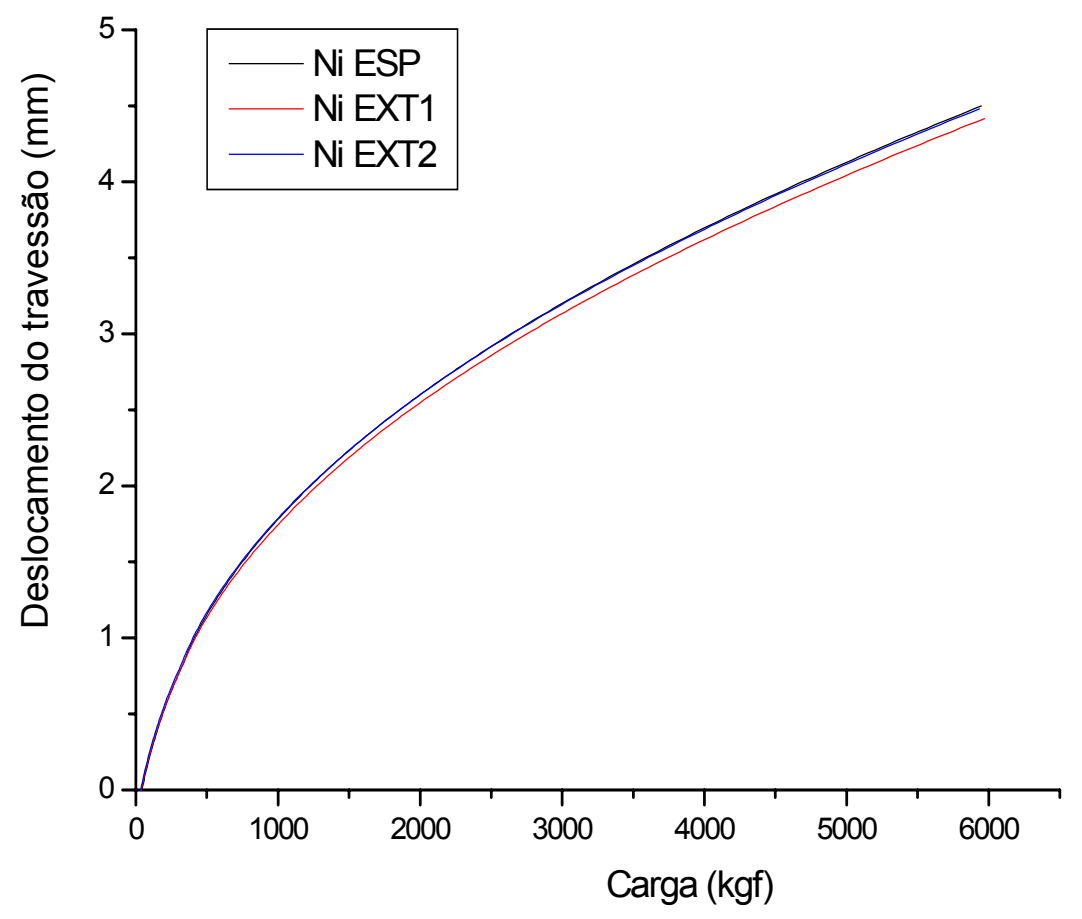

FIGURA 5 - Curvas de deslocamento x carga obtidas na compactação de pós de níquel em três diferentes condições. 


\subsubsection{Compactação de pós - velocidade de compactação}

Nestes ensaios as amostras foram identificadas de acordo com a seguinte nomenclatura:

\section{Exemplo: Ni- 3}

Em que:

Ni representa o tipo de material compactado (níquel);

3 é a velocidade de compactação (ou do travessão da máquina) em mm/min.

Para cada condição de velocidade e/ou carga foram realizados dois testes de compactação. Dos resultados obtidos, constatou-se que, variando-se as velocidades da ponte de 2 a $10 \mathrm{~mm} / \mathrm{min}$, não houve alteração na forma dos gráficos, conforme verificado na FIG. 6. Foi estipulada, então, uma velocidade de $5 \mathrm{~mm} / \mathrm{min}$ como padrão para realização das compactações. A carga máxima padrão foi de 6 tf (ou pressão de $400 \mathrm{MPa}$ ), conforme já comentado.

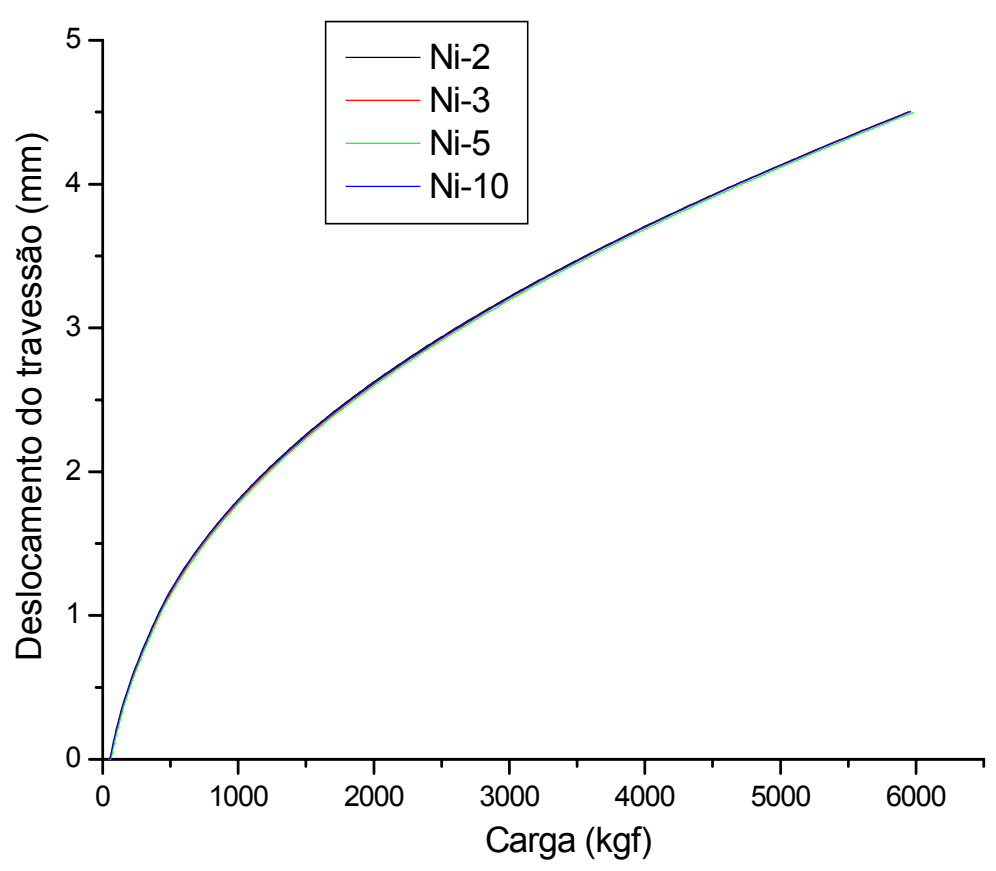

FIGURA 6 - Curvas de 4 ensaios de compactação de pó de Ni com variação nas velocidades do travessão (2; 3, 5 e $10 \mathrm{~mm} / \mathrm{min})$. 


\subsection{Ensaios de compressibilidade: misturas ativadas mecanicamente}

\subsubsection{Pós utilizados}

\subsubsection{Pós de alumínio (Al)}

Foram utilizados dois lotes de pós de Al, ambos fornecidos pela ALCOA do Brasil, obtido por atomização gasosa e com pureza de 99,7\%, a saber:

\section{(a) Pó de alumínio 1: Al L1}

Designação do fabricante: pó tipo 123, lote 01101BZ.

Este pó estava há muitos anos armazenado em sua embalagem original (lata de $5 \mathrm{~kg}$ ), encontrando-se em elevado estado de aglomeração. Pequenos blocos do pó, carregados num copo de polietileno sem bolas, foram agitados por meia hora no moinho SPEX. Em seguida o pó foi peneirado (peneiramento vibratório), aproveitando-se a fração passante na peneira de malha 325 mesh (uma vez que o pó do tipo 123 é quase todo passante nesta malha). O processo de desaglomeração mecânica em copo de polietileno foi utilizado porque a alternativa de raspagem do pó com espátula mostrou-se ineficiente (pequenas porções de pó eram obtidas após muito tempo de raspagem). Foi descartada também a desaglomeração em copos de aço, em razão do menor volume interno do copo, o que diminui a eficiência do processo.

(b) Pó de alumínio 2: Al L2

Designação do fabricante: pó tipo 123, lote 72290.

\subsubsection{Pó de nióbio (Nb)}

O pó de nióbio foi fornecido pela UNESP de Lorena (ex FAENQUIL) e foi obtido por hidretação, moagem e desidretação. O pó utilizado neste trabalho (denominação $\mathrm{Nb}$ ) foi classificado de forma a se aproveitar a fração passante pela peneira de malha 200 mesh e retida na peneira de malha de 325 mesh (-200 $+325 \#)$.

\subsubsection{Ativação mecânica por moagem de alta energia}

Todas as cargas de moagem foram preparadas individualmente. Nas pesagens foi utilizada uma balança analítica $(0,0001 \mathrm{~g})$. Os pós de alumínio e 
nióbio foram inicialmente pesados em proporção equivalente à razão atômica 3:1 (estequiometria do $\mathrm{NbAl}_{3}$ ). As massas de $\mathrm{Nb}$ e $\mathrm{Al}$ utilizadas foram de 5,345 g e de $4,655 \mathrm{~g}$, respectivamente, perfazendo $10 \mathrm{~g}$ de pó em cada moagem (suficiente para compactar duas pastilhas de $4 \mathrm{~g}$ cada, restando $2 \mathrm{~g}$ para caracterização). O agente controlador de processo (ACP), utilizado como inibidor da soldagem de partículas durante a moagem, foi o ácido esteárico (um ácido graxo utilizado na forma de pó, sólido a temperaturas de até $\left.69^{\circ} \mathrm{C}\right)^{[54]}$, nas proporções de 1 e $2 \%$ em massa. As bolas para a moagem foram de aço Cr-V (diâmetro 7,14 mm), em quantidade estabelecida pela razão bola- pó de 10:1 (71 bolas).

O carregamento de pós e bolas nos copos de moagem de aço ocorreu em atmosfera de argônio dentro de uma caixa de luvas. A ativação mecânica ocorreu num moinho agitador do tipo SPEX (alta energia) por diferentes períodos de tempo (1 e 2 horas).

As amostras foram identificadas de acordo com a seguinte nomenclatura:

Ex: $\quad$ NbAl L2 1h, 1\%: Mistura dos pós Nb e Al L2, ativada por 1h, com 1\% de ACP (ácido esteárico).

Após o término da moagem, o descarregamento também ocorreu no interior da caixa de luvas, nas quais os pós foram passivados por uma hora antes de serem expostos ao ar livre. A passivação consiste na formação de um filme fino de óxido na superfície altamente reativa das partículas que as protege, neste caso, de reações altamente exotérmicas de oxidação com o oxigênio do ar.

\subsubsection{Dados obtidos nas compactações}

As compactações foram executadas seguindo-se o procedimento definido anteriormente. Primeiramente, foram traçadas curvas de carga versus deslocamento do travessão. O deslocamento do travessão após a correção, foi tomado como a variação de altura do compactado na matriz, que foi associada à variação de volume do pó durante a compactação no interior da matriz (o diâmetro da matriz foi considerado constante durante a compactação). Posteriormente, os dados foram transformados e reapresentados na forma de curvas de densidade relativa (\% da densidade teórica) versus pressão (MPa). 
Finalmente, aos dados foram aplicadas cinco equações de compressibilidade (todas baseadas em modelos de primeira ordem) ${ }^{[45]}$ atualmente em uso, que estabelecem relações entre a pressão aplicada e a variação de volume ou densidade relativa. As equações foram comparadas de modo a se identificar a equação que melhor se ajustasse aos dados deste trabalho. Na tentativa de se estabelecer um melhor ajuste aos dados, foi possível propor uma nova equação de compressibilidade.

\subsection{Caracterização}

\subsubsection{Analise granulométrica dos pós}

A distribuição de tamanho de partícula dos pós de alumínio e de nióbio de partida foi determinada por difração a LASER no analisador de tamanho de partículas CILAS 1064 líquido. As análises foram realizadas em água com auxílio de ultra-som, e o agente dispersante utilizado foi o pirofosfato de sódio. Foram obtidos, assim, os histogramas da distribuição de freqüência relativa (\%) em função do tamanho das partículas $(\mu \mathrm{m})$.

\subsubsection{Microscopia eletrônica de varredura (MEV)}

Os pós de alumínio, os de nióbio e também os pós das misturas mecanoativadas foram caracterizados por microscopia eletrônica de varredura. As amostras foram dispersas a seco sobre um suporte metálico sobre o qual foi aplicada uma fita adesiva de dupla face. O recobrimento foi feito com carbono. Os elétrons secundários e retro-espalhados foram utilizados para a formação da imagem.

\subsubsection{Difração de raios $X$}

A mistura L2 ativada pelo maior tempo e com a menor quantidade de ACP foi caracterizada por difração de raios $X$ para verificação da formação de eventual fase intermetálica, num difratômetro marca Rigaku, modelo multiflex com radiação Cu Ka. 


\section{RESULTADOS E DISCUSSÃO}

\subsection{Caracterização dos pós de alumínio e nióbio de partida}

\subsubsection{Pós de alumínio}

Na FIG. 7 encontram-se as imagens de MEV (elétrons secundários) dos pós de alumínio L1 e L2. Nota-se em ambos os casos a típica morfologia semiesférica inerente ao processo de atomização gasosa. Pode-se notar claramente que as partículas do Al L1 são maiores (micrografias da parte superior).

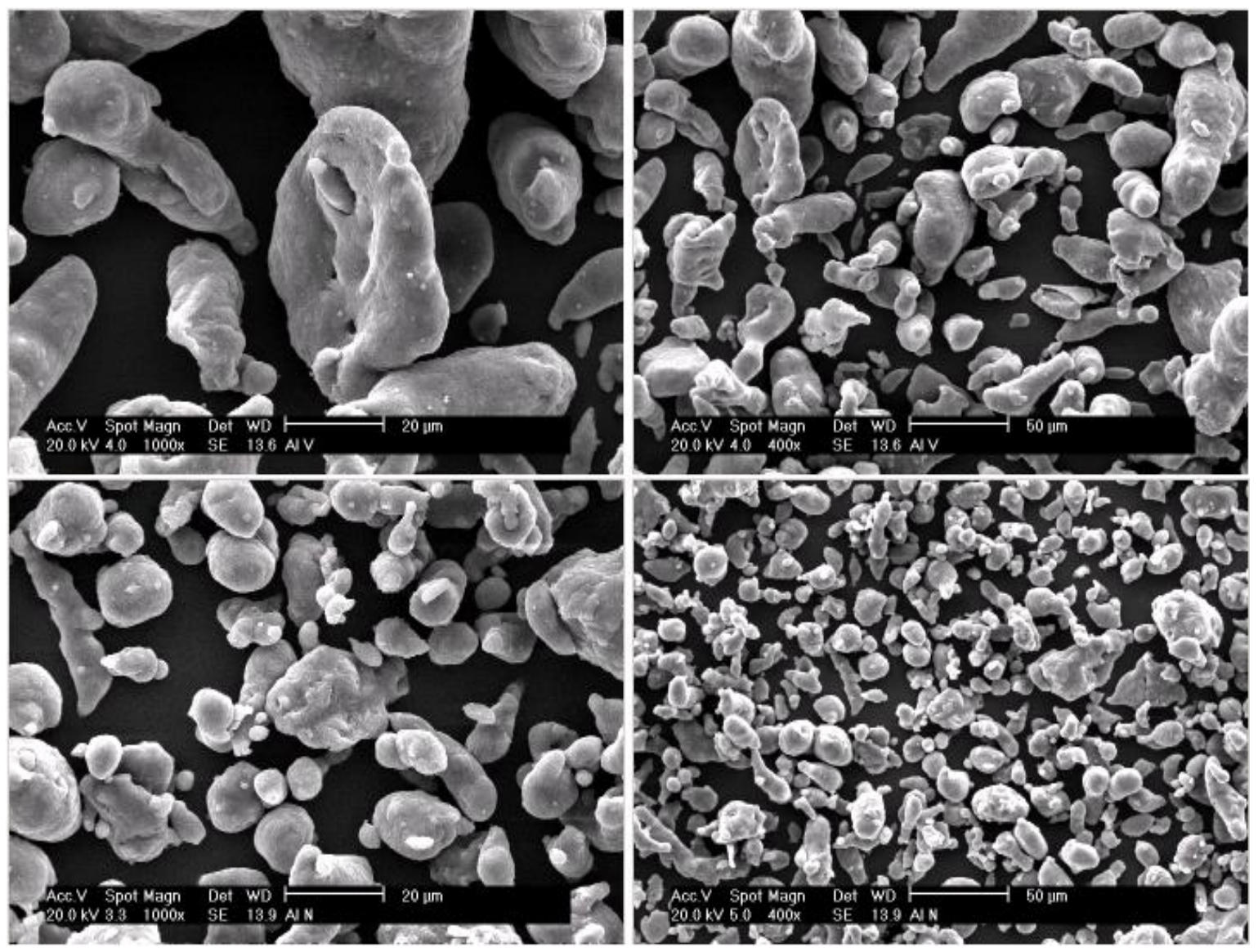

FIGURA 7 - Micrografias de varredura (elétrons secundários) dos pós de Al L1 (parte superior) e Al L2 (parte inferior) antes da moagem.

Na TAB. 2 e nas FIG. 8 (A e B) são apresentados alguns parâmetros relativos à distribuição do tamanho de partícula e os histogramas de distribuição granulométrica dos pós de alumínio L1 e L2, respectivamente. 
TABELA 2 - Resultados da distribuição do tamanho de partícula dos pós de alumínio L1 e L2, onde d é o diâmetro.

\begin{tabular}{|c|c|c|c|c|}
\hline Amostra & $\mathrm{d}$ a $10 \%(\mu \mathrm{m})$ & $\mathrm{d}$ a $50 \%(\mu \mathrm{m})$ & $\mathrm{d}$ a $90 \%(\mu \mathrm{m})$ & $\mathrm{d}$ médio $(\mu \mathrm{m})$ \\
\hline Al L1 & 14,9 & 31,3 & 57,9 & 34,2 \\
\hline Al L2 & 9,2 & 17,5 & 30,8 & 18,8 \\
\hline
\end{tabular}

Os resultados mostram uma diferença bastante significativa entre os dois pós que, a princípio, são do mesmo tipo (123 da ALCOA). As partículas dos pós de alumínio L1 podem ter sofrido uma certa soldagem a frio, o que explicaria o maior tamanho de partícula. É difícil, entretanto, uma conclusão segura, valendose da análise de varredura feita aqui. Outra possibilidade, que parece ser mais provável, é a de que houve um erro do fornecedor na identificação do lote. De qualquer maneira, os dois lotes são ou pelo menos estão diferentes. 


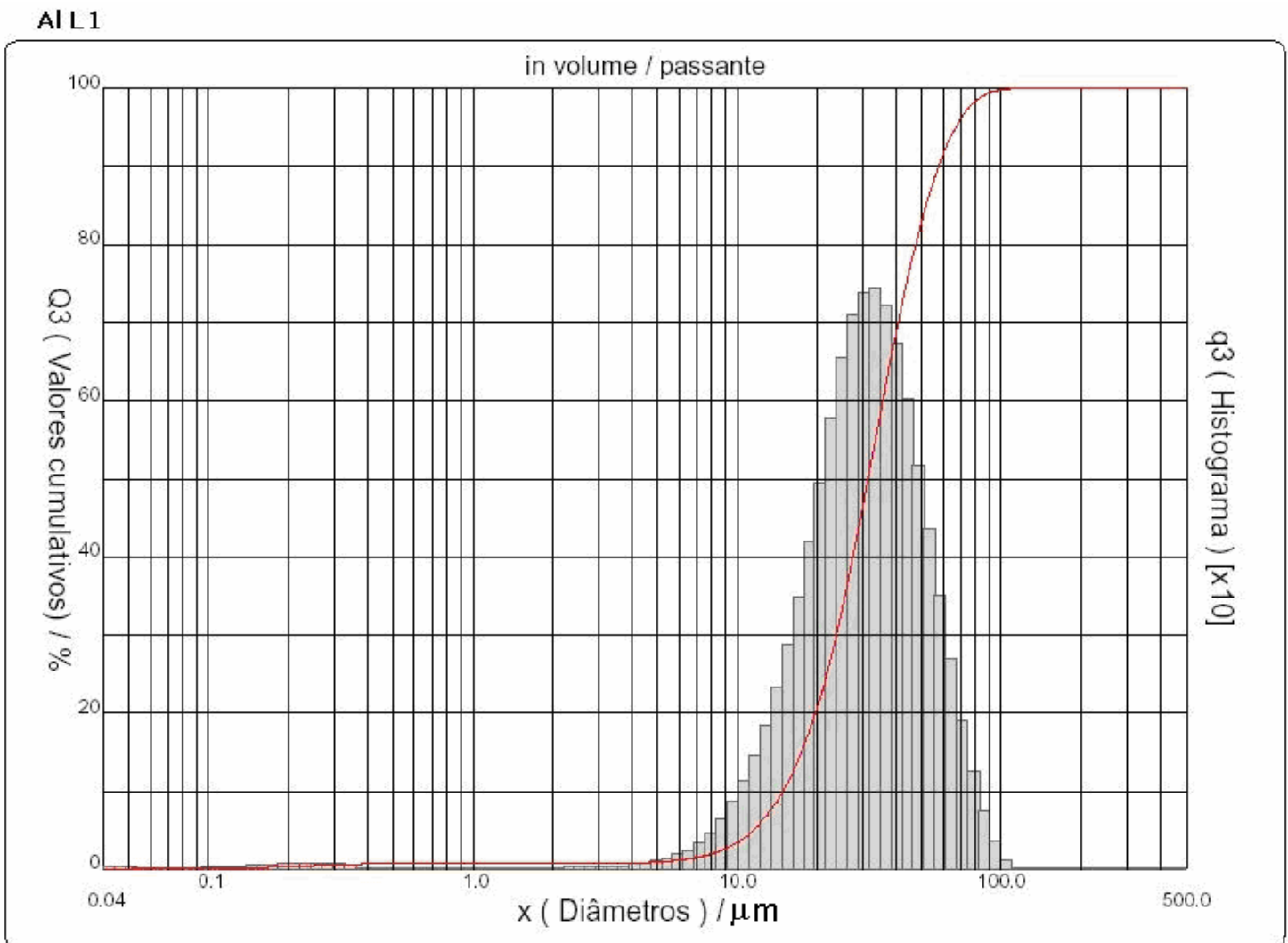

A

Al L2

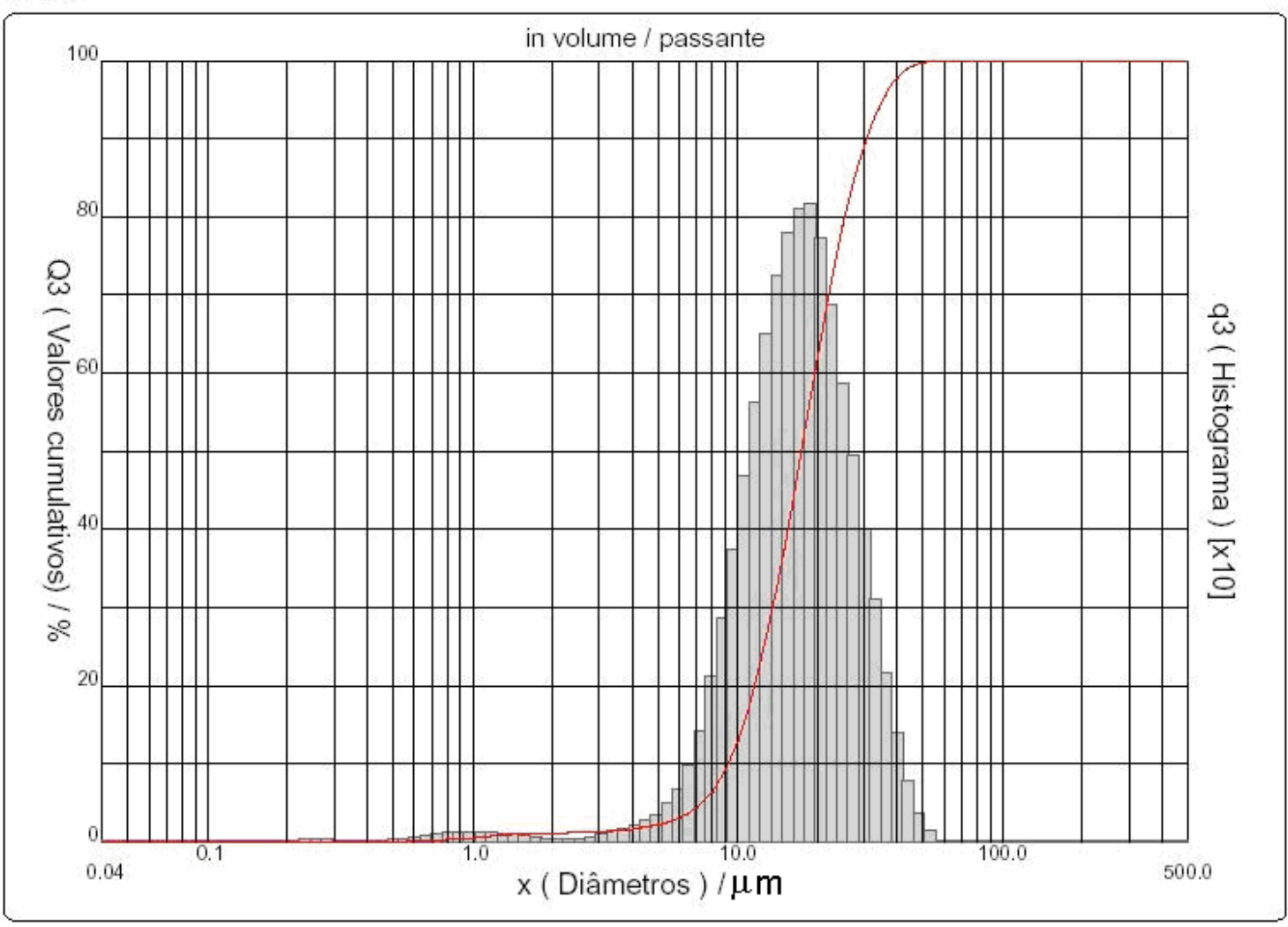

B

FIGURA 8 - Distribuição do tamanho de partícula dos pós Al L1 (A) e Al L2 (B). 
As diferenças entre os pós de alumínio foram refletidas na compressibilidade dos mesmos, conforme se observa na FIG. 9.

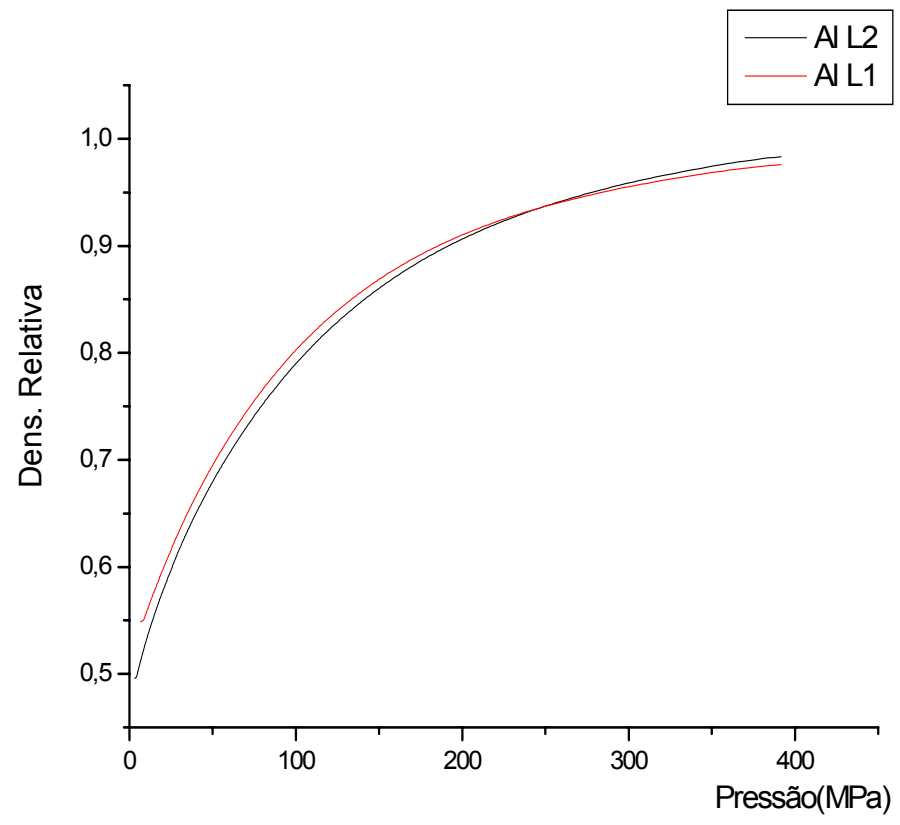

FIGURA 9 - Curvas de compressibilidade dos pós de alumínio Al L1 e Al L2

O Al L2 apresentou densidade relativa inicial (com aplicação de pré-carga de $30 \mathrm{kgf}$ ) mais baixa que o $\mathrm{Al}$ L1, porém sofreu densificação um pouco maior com o aumento da pressão aplicada. Isto ocorre porque inicialmente o Al L2 tem menor tamanho médio de partícula que o $\mathrm{Al} L 1$, o que faz que a densidade aparente do primeiro seja mais baixa (atrito entre as partículas é maior). Com o aumento da pressão de compactação, nota-se que o Al L2 ultrapassa a densidade do Al L1 tomando-se por base uma mesma pressão. O resultado indica que o $\mathrm{Al}$ L2 como recebido é um pouco mais dúctil que o $\mathrm{Al}$ L1. Nota-se que no início a taxa de densificação é elevada como resultado do rearranjo das partículas em baixas pressões. Embora a taxa de densificação seja decrescente, uma vez que o alumínio é bastante dúctil, densidades relativas elevadas são obtidas, atingindose a $400 \mathrm{MPa}$ valores da ordem de $97 \%$, o que está compatível com valores encontrados na literatura ${ }^{[55]}$. 


\subsubsection{Caracterização do pó de nióbio}

O resultado da análise de distribuição granulométrica para o pó de $\mathrm{Nb}$ quanto ao diâmetro médio foi de 42,9 $\mu \mathrm{m}$. Na FIG. 10 (A e B) são mostrados uma micrografia do pó em questão e o histograma da distribuição do tamanho de partículas, respectivamente.

Na TAB. 3 são apresentados alguns parâmetros relativos à distribuição do tamanho de partícula do pó de $\mathrm{Nb}$.

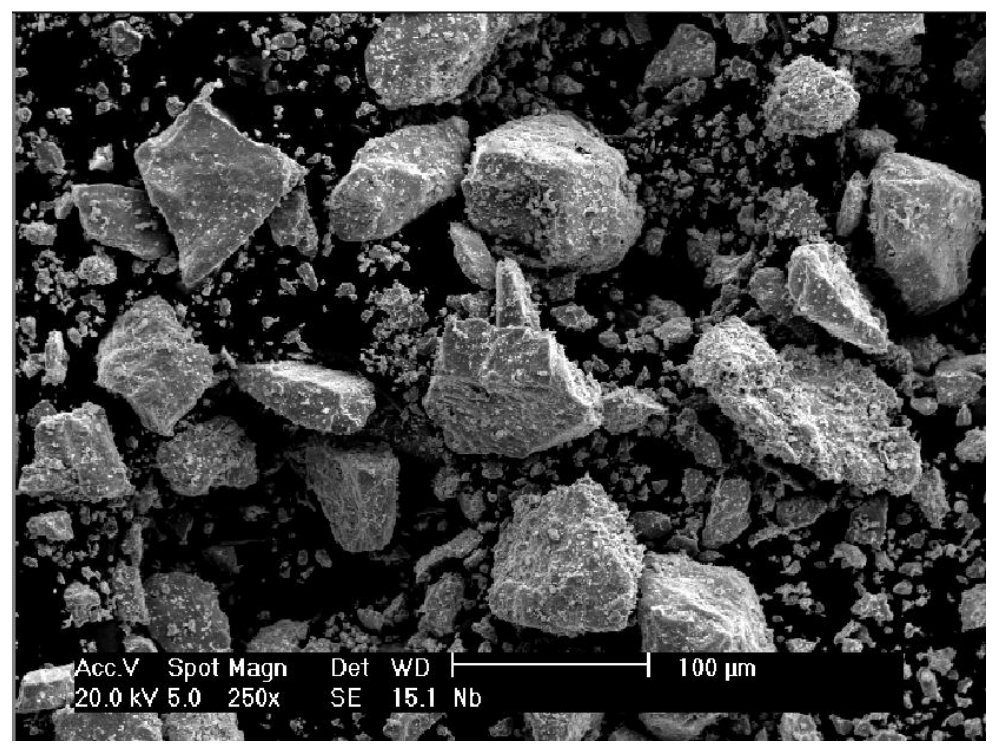

A

$\mathrm{Nb}-200 \#+325 \#$

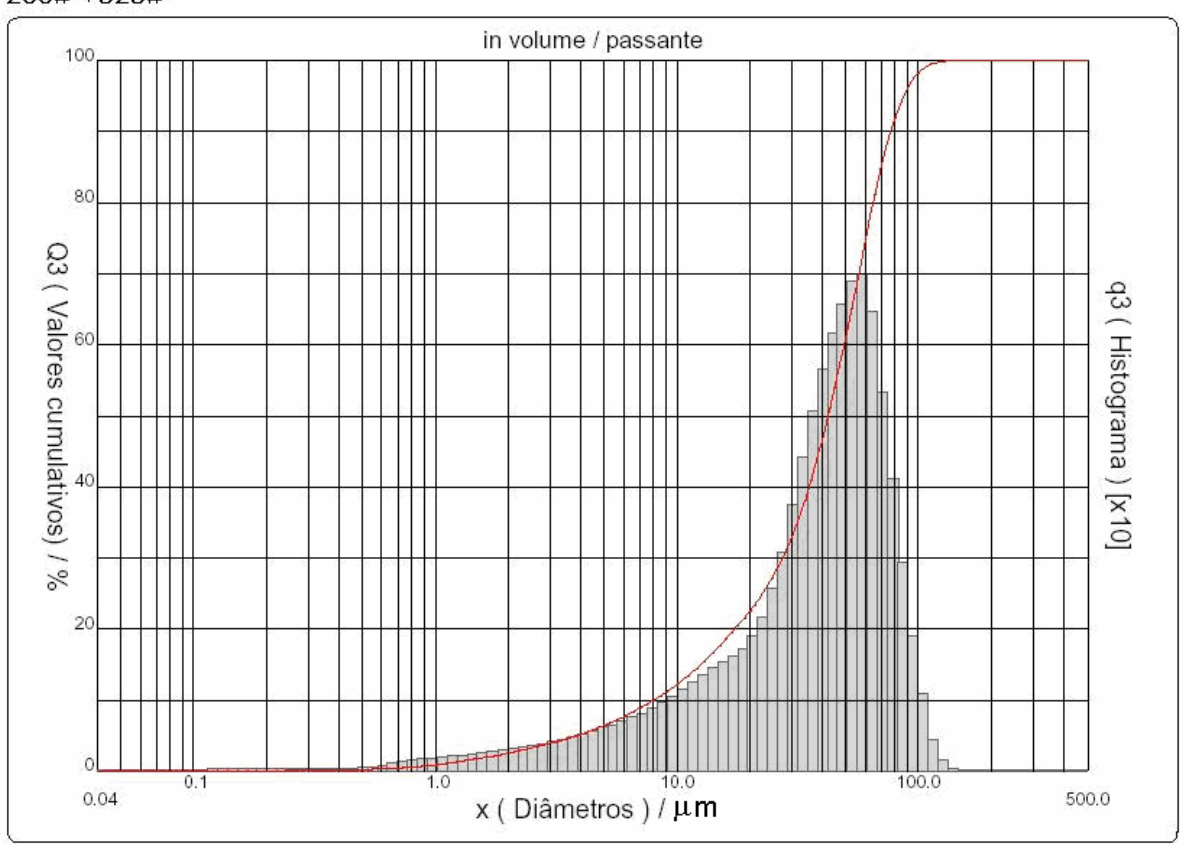

B

FIGURA 10- Micrografia (A) e o gráfico da distribuição do tamanho de partículas do pó de nióbio(B). 
Tabela 3- Resultados da distribuição do tamanho de partícula do pó de nióbio.

\begin{tabular}{|c|c|c|c|c|}
\hline Amostra & d a $10(\mu \mathrm{m})$ & d a $50 \%(\mu \mathrm{m})$ & d a $90 \%(\mu \mathrm{m})$ & d méd. $(\mu \mathrm{m})$ \\
\hline $\mathrm{Nb}-200+325 \#$ & 8,1 & 42,2 & 76,8 & 42,9 \\
\hline
\end{tabular}

O pó de nióbio, embora acima de 325\#, apresenta também partículas abaixo disso, como visto no gráfico e na micrografia, o que indica que houve aglomeração destas finas partículas, prejudicando sua classificação granulométrica.

\subsection{Caracterização das misturas de pós mecanicamente ativadas}

\subsubsection{Microscopia eletrônica de varredura e análise do tamanho de partícula}

A maior ductilidade do $\mathrm{Al}$ L2 em relação ao $\mathrm{Al} L 1$ é evidenciada nas micrografias das misturas ativadas por $0,5 \mathrm{~h}$ e com 1\% de ACP (FIG $11 \mathrm{~A}$ ). Os contrastes de cor cinza mais escuro são referentes ao $\mathrm{Al}$, e os mais claros, ao $\mathrm{Nb}$.

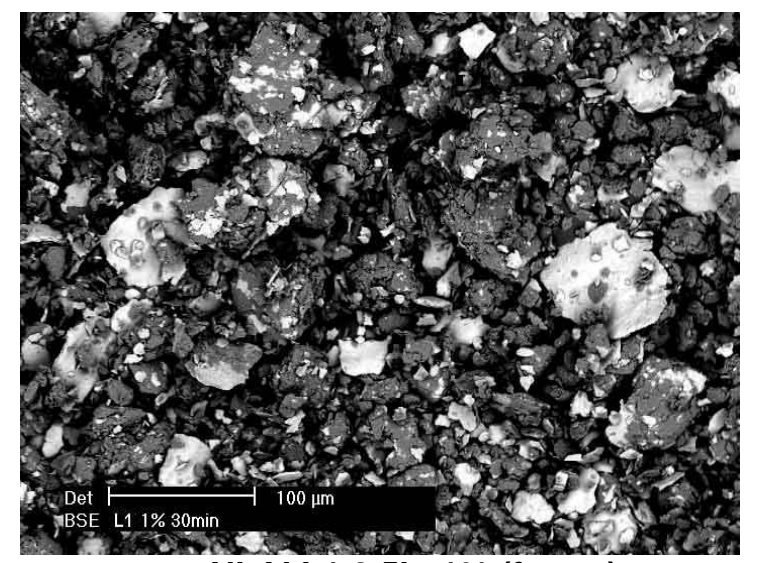

$\mathrm{NbAI}$ L1 0,5h. 1\% (forma)

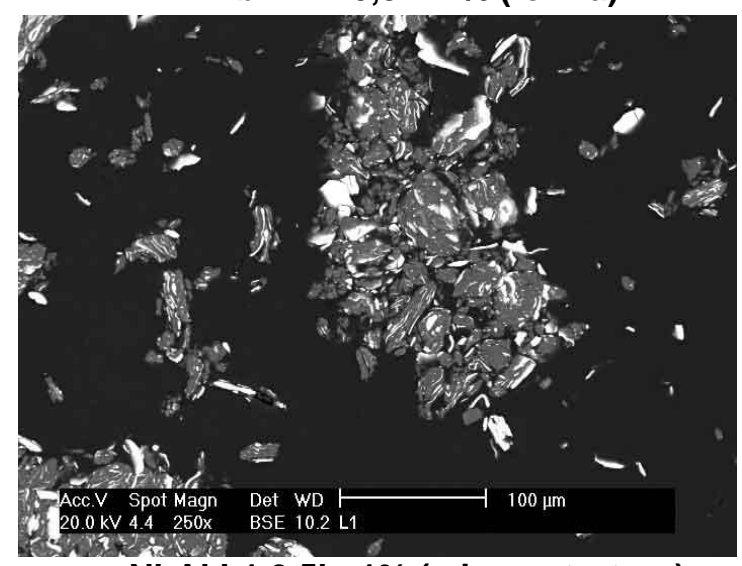

NbAI L1 0,5h. 1\% (microestrutura)

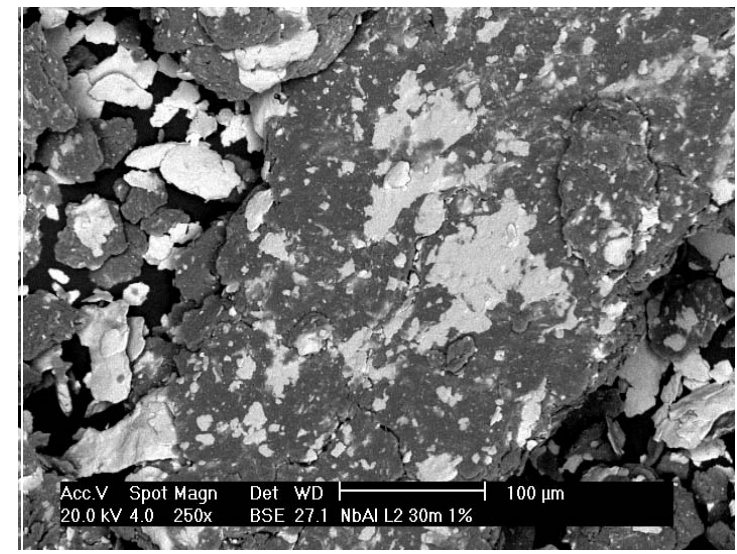

NbAl L2 0,5h. 1\% (forma)

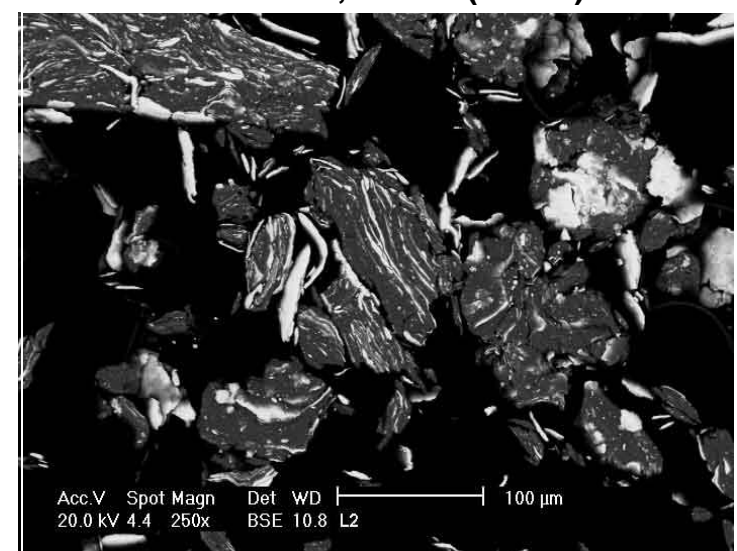

NbAl L2 0,5h. 1\% (microestrutura)

FIGURA 11 A- Micrografias de varredura (imagem de elétrons retro-espalhados) da forma e da microestrutura dos agregados das misturas, ativadas mecanicamente por $0,5 \mathrm{~h}$, com $1 \%$ de ACP. 
A cor preta é referente à base do suporte e não possui partículas.

Pode-se observar na mistura NbAl L2 agregados grandes (alguns maiores que $500 \mu \mathrm{m}$, o que impediu a análise de distribuição granulométrica em função da ultrapassagem da escala) com estrutura lamelar, indicando grande quantidade de deformação inicial. Além disso, o Al L2 tem tamanho médio de partícula menor que o L1, maior área de superfície específica e, portanto, maior atrito entre as partículas, o que favorece a deformação e a soldagem.

Na mistura NbAl L1 ativada por 0,5 h o tamanho médio final de partícula é 26,0 $\mu \mathrm{m}$, ou seja ainda menor que o tamanho de partícula do Al L1 (34,2 $\mu \mathrm{m})$, indicando que para esta condição o tempo de moagem é mais eficiente na redução do tamanho médio de partícula. Nas micrografias dessa mistura nota-se que embora também haja grande quantidade de deformação inicial, há pouca agregação em virtude da menor ductilidade do Al L1 e do seu tamanho médio de partícula maior, o que diminui a fricção e também a soldagem entre as partículas (menor área de superfície específica). Também é visível boa quantidade de partículas soltas de nióbio nas duas misturas, devido ao pouco tempo de ativação.

Aumentando-se a quantidade de ACP para 2\% e mantendo-se o mesmo tempo de moagem, ocorre uma diminuição da fricção entre partículas nas duas misturas, acarretando menor agregação que na situação anterior, sobretudo na mistura L2, sendo obtido como tamanho médio de partícula $33,0 \mu \mathrm{m}$ para esta última e 21,1 $\mu \mathrm{m}$ para a mistura L1. É visível, além disso, a grande quantidade de partículas de $\mathrm{Nb}$ soltas, comprovando que a ação mais acentuada do ACP dificulta a soldagem (FIG 11 B). A TAB. 4 mostra a distribuição do tamanho de partícula de todas as misturas deste trabalho.

TABELA 4 - Tamanhos médios de partícula $(\mu \mathrm{m})$ das misturas $\mathrm{NbAl}$, ativadas mecanicamente em diversas condições.

\begin{tabular}{|c|c|c|c|c|}
\hline $\begin{array}{c}\text { Tempo de } \\
\text { ativação (h) }\end{array}$ & L1 1\%ACP & L1 2\% ACP & L2 1\% ACP & L2 2\% ACP \\
\hline 0,5 & 26,0 & 21,1 & ------------- & 33,0 \\
\hline 1 & 36,5 & 10,1 & ------------- & 23,6 \\
\hline 2 & 21,7 & 12,00 & 21,1 & 22,5 \\
\hline 2,5 & 18,2 & ------------------ & 24,6 & -----------------. \\
\hline
\end{tabular}


Na TAB. 4 da página anterior não foi possível obter a distribuição de tamanho de partícula da mistura NbAl L2 com 1\% de ACP e tempos de ativação de meia e uma hora em virtude de agregados cujos tamanhos ultrapassaram a escala do analisador. A análise das misturas L1 e L2 com 2,5 horas de ativação e $2 \%$ de ACP não foi necessária, como será visto mais adiante.

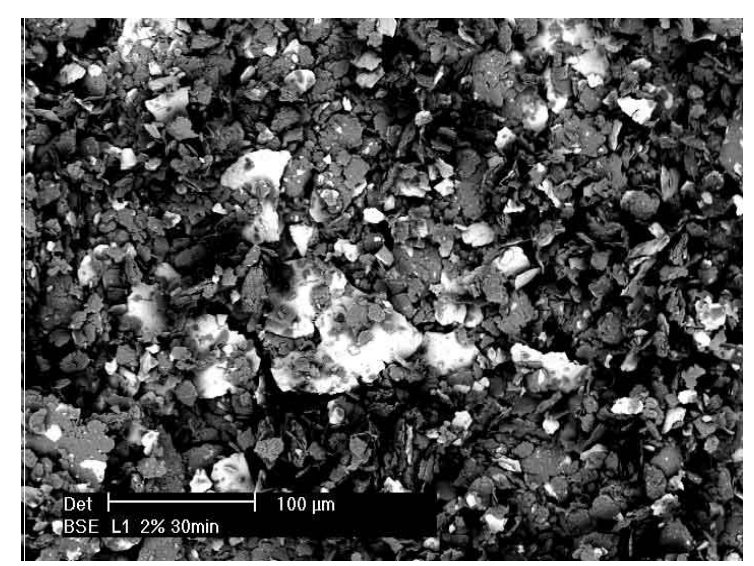

NbAl L1 0,5h. 2\% (forma)

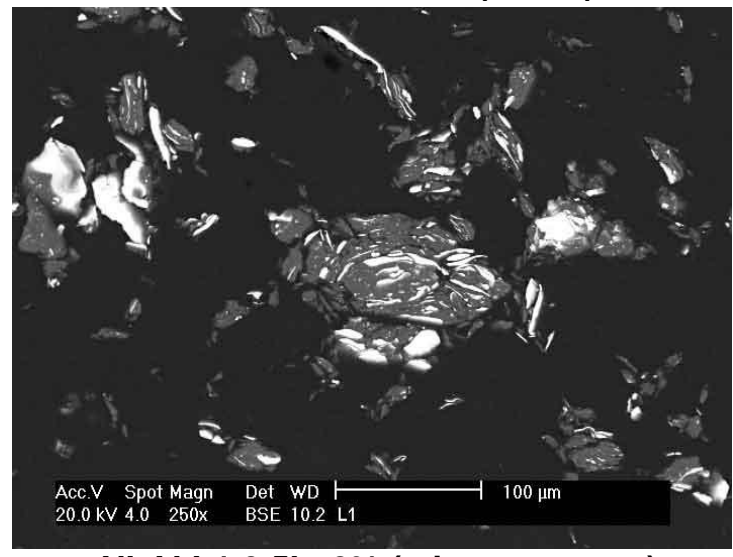

NbAl L1 0,5h. 2\% (microestrutura)

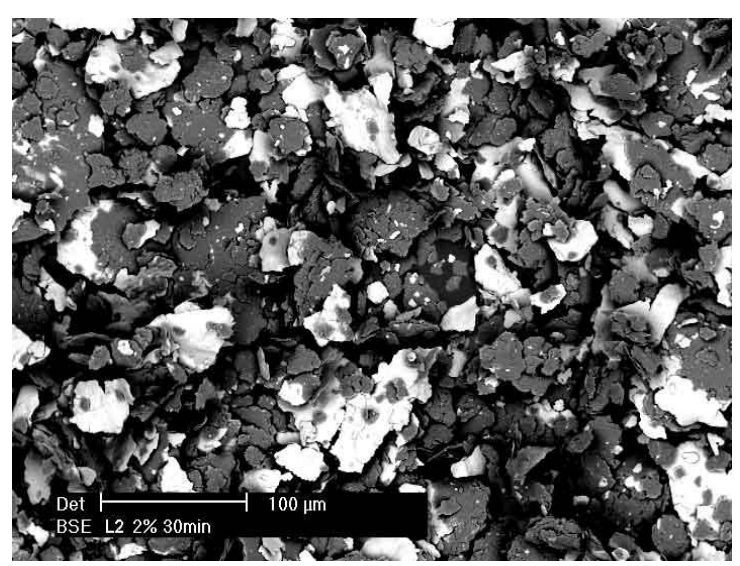

NbAl L2 0,5h. 2\% (forma)

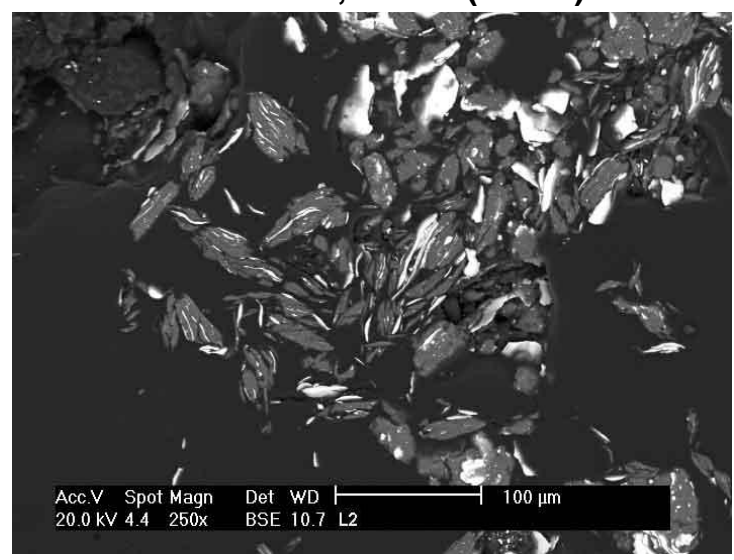

NbAl L2 0,5h. 2\% (microestrutura)

FIGURA 11 B- Micrografias de varredura (imagem de elétrons retro-espalhados) da forma e da microestrutura dos agregados das misturas, ativadas mecanicamente por $0,5 \mathrm{~h}$, com $2 \%$ de ACP.

Nas FIG. 12 (A e B) são mostradas as distribuições granulométricas das misturas NbAl L1 e L2 ativadas por 0,5 h com 1\% de ACP e nas FIG.13 (A e B) idem, com $2 \%$ de ACP. 


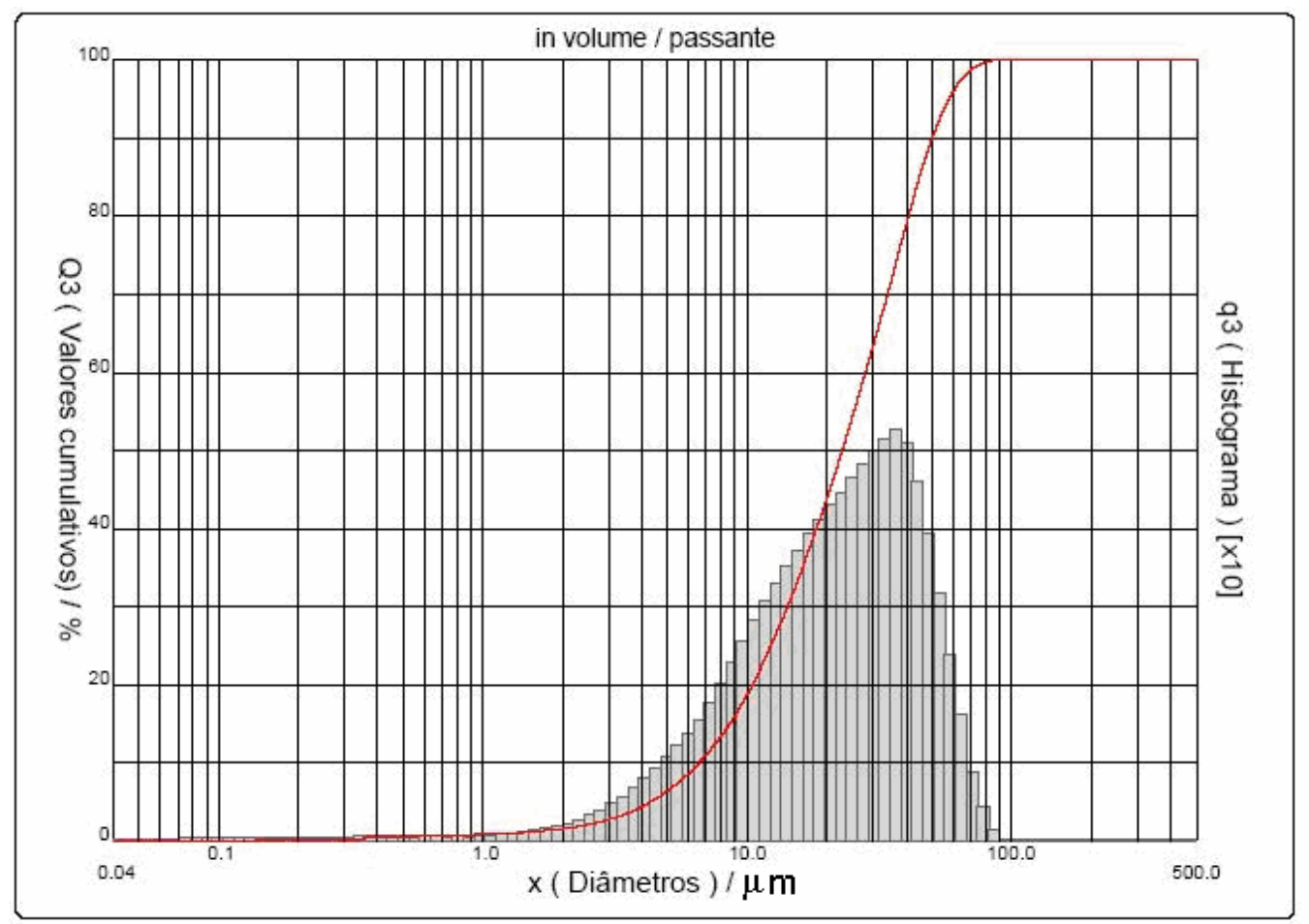

A

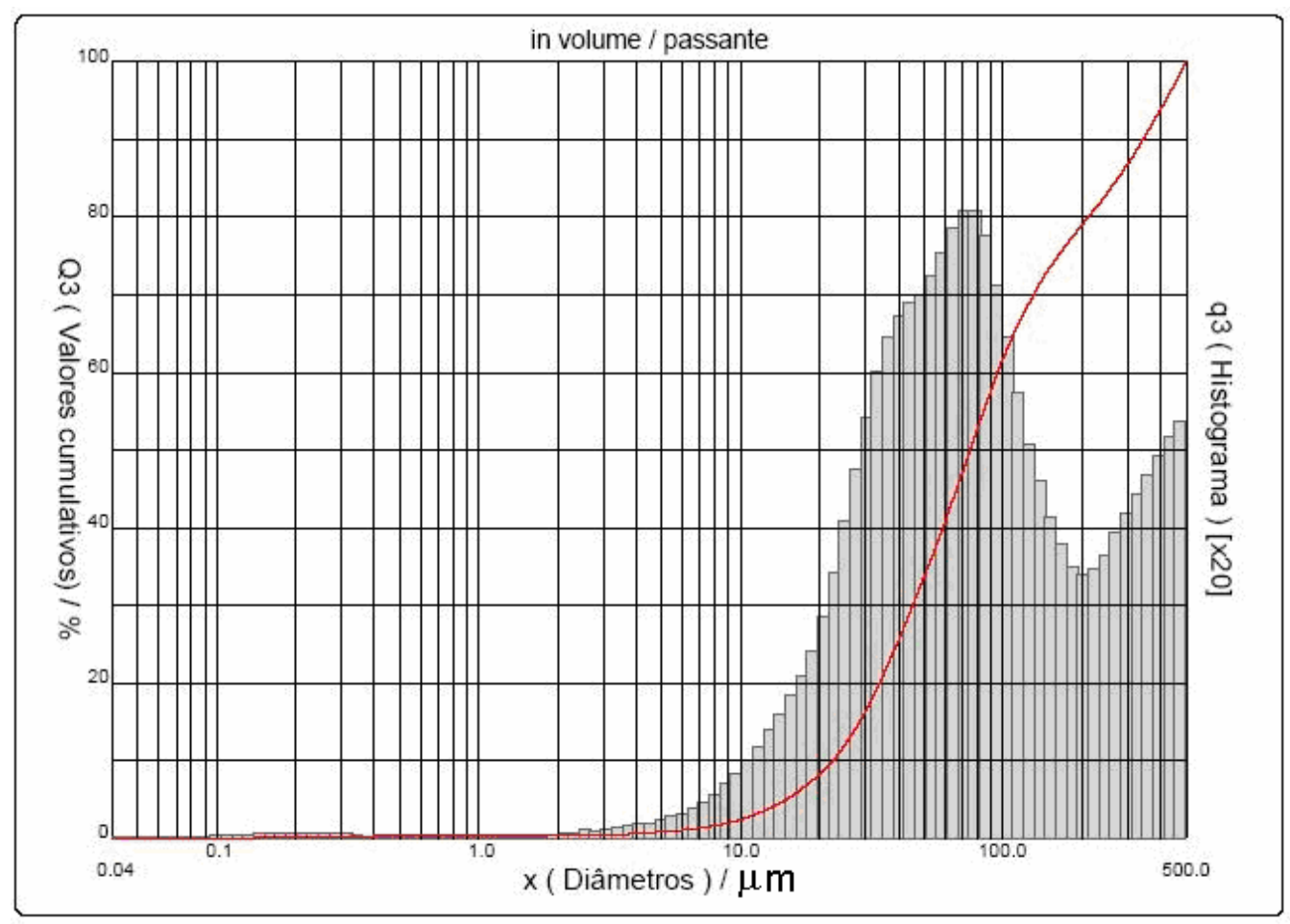

B

FIGURA 12- Distribuição granulométrica das misturas NbAl L1 (A) e NbAL2 (B) ativadas por $0,5 \mathrm{~h}$, com $1 \%$ de ACP. A mistura NbAl L2 apresentou agregados maiores que $500 \mu \mathrm{m}$, o que fez com que a escala máxima do analisador fosse ultrapassada, prejudicando o resultado. 


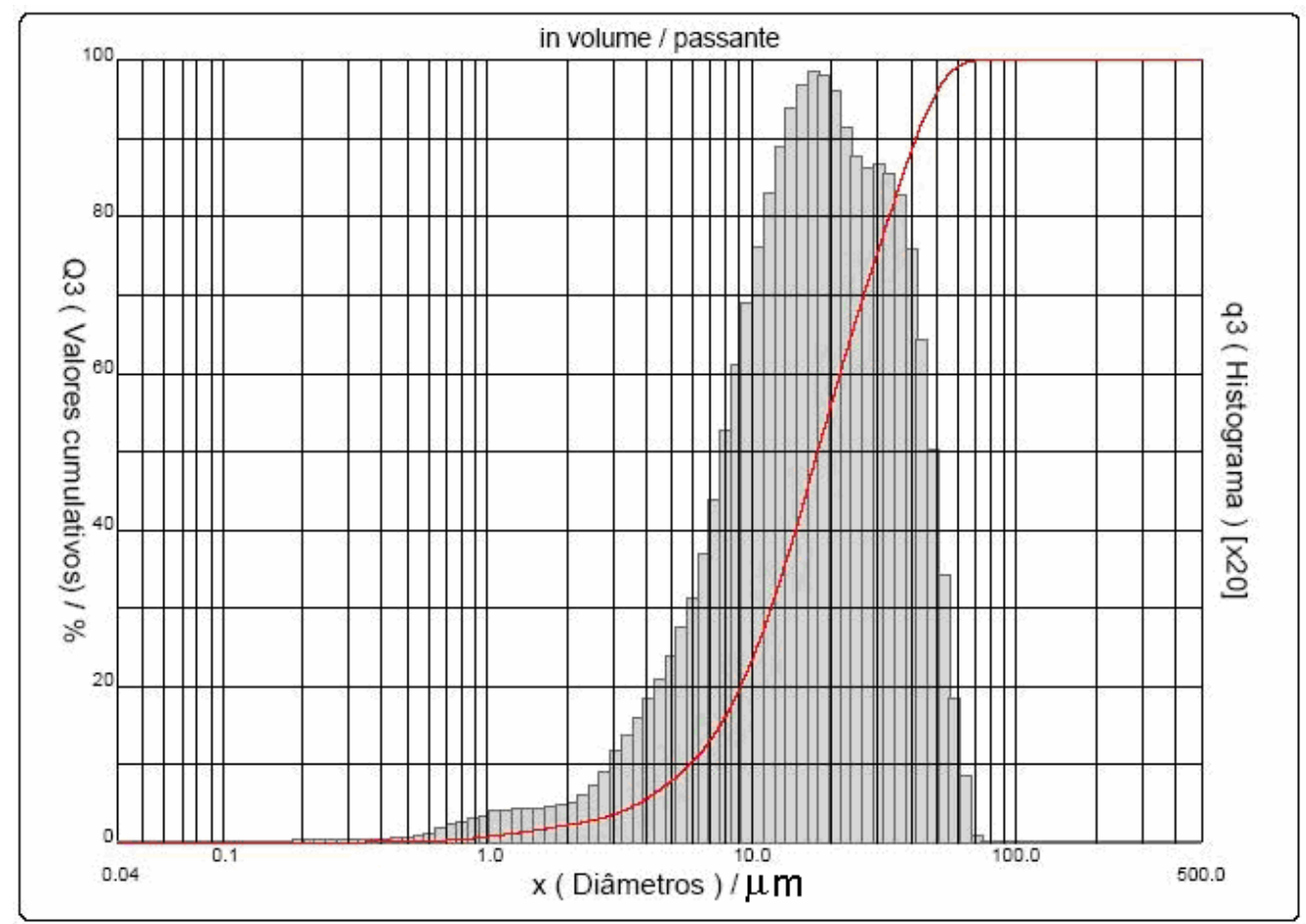

A

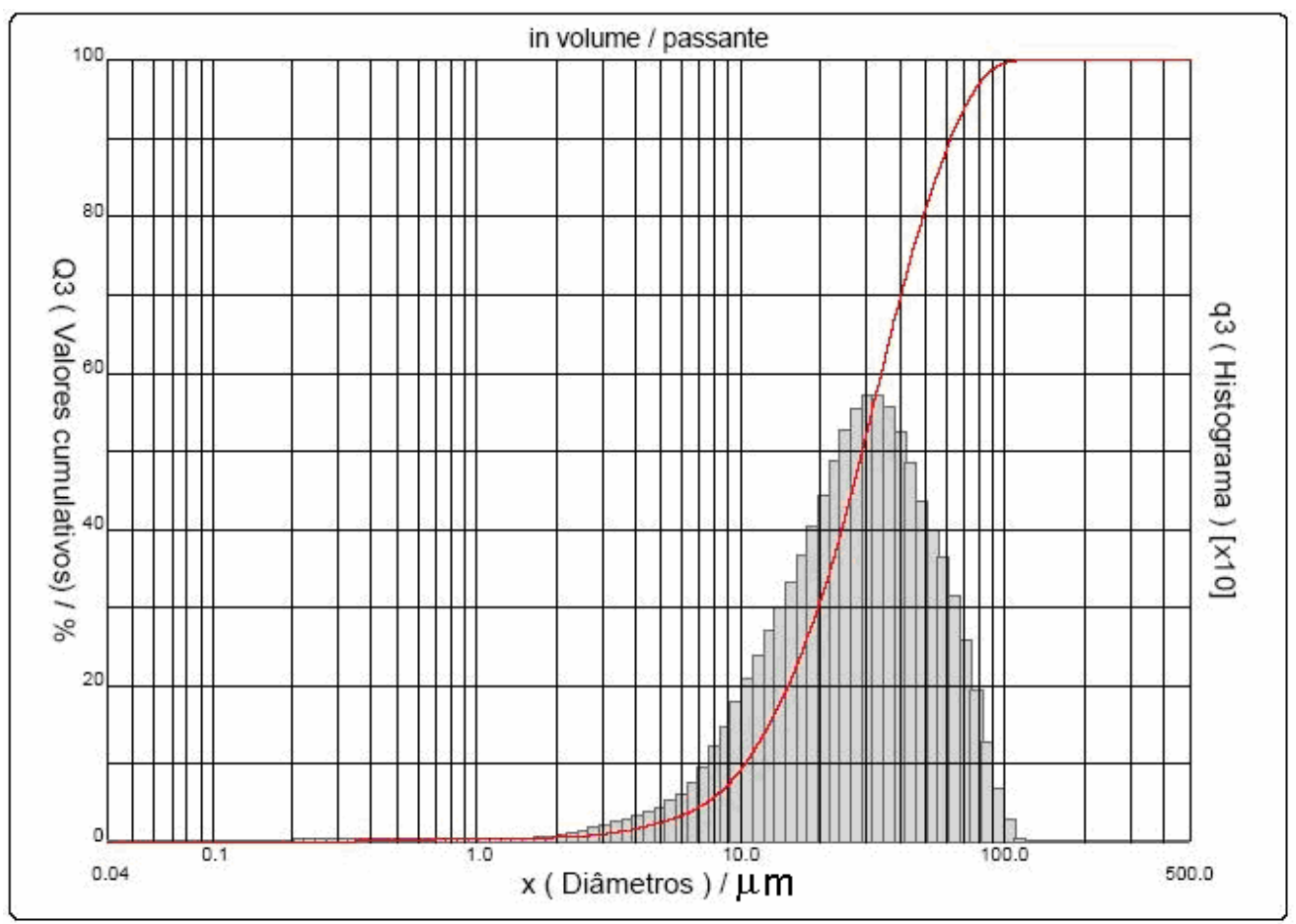

B

FIGURA 13- Distribuição granulométrica das misturas NbAI L1 (A) e NbAL2 (B) ativadas por $0,5 \mathrm{~h}$, com $2 \%$ de ACP. 
Na FIG. 14 A encontram-se as micrografias das misturas de pós ativadas mecanicamente por $1 \mathrm{~h}$ e $1 \%$ de ACP. A mistura NbAl L2, (a exemplo da mesma mistura com tempo de ativação de $0,5 \mathrm{~h}$ ) apresentou alguns agregados grandes, sendo alguns maiores que $500 \mu \mathrm{m}$, o que impediu uma análise correta de distribuição granulométrica, pois o limite do equipamento foi excedido. A mistura L1, por sua vez, formou agregados menores (abaixo de $100 \mu \mathrm{m}$ ). Isto acontece porque o Al L2, com tamanho médio de partícula menor que o Al L1, possui maior atrito e também maior área de superfície específica, o que faz com que a quantidade de ACP (igual para as duas misturas de pós) continue atuando com maior eficiência na mistura L1, que tem menor área de superfície geral, diminuindo a fricção entre partículas dessa mistura em relação à L2 e desfavorecendo ou retardando a formação de agregados. $O$ tamanho médio de partícula da mistura L1 nesta condição é de 36,5 $\mu \mathrm{m}$. É possível notar uma melhora da homogeneidade dos agregados em ambas as misturas;

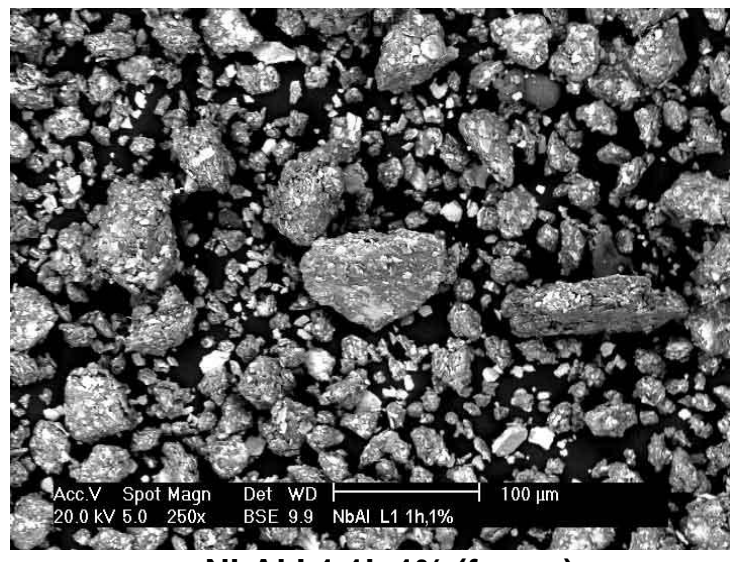
NbAI L1 1h 1\% (forma)

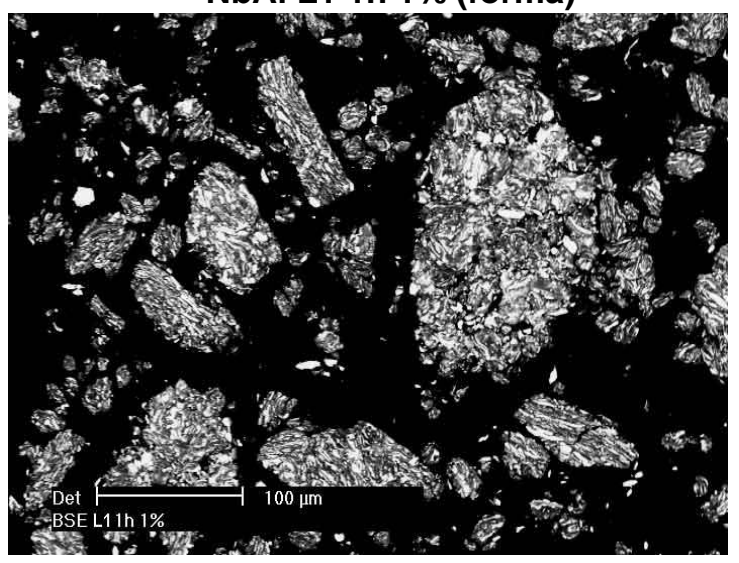

NbAI L1 1h 1\% (microestrutura)

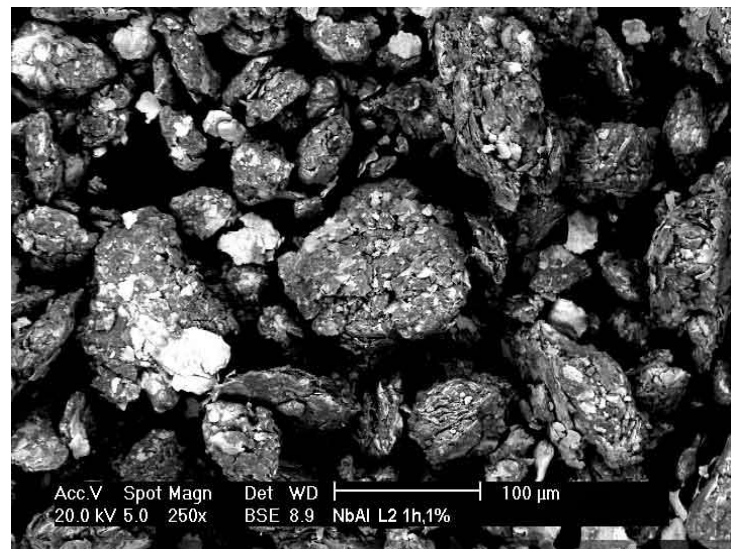

NbAl L2 1h 1\% (forma)

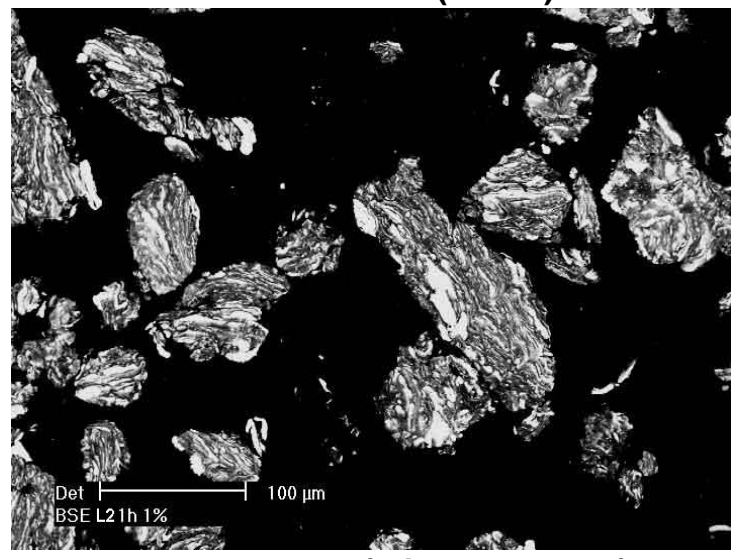

NbAl L2 1h 1\% (microestrutura)

FIGURA 14 A- Micrografias de varredura (imagem de elétrons retro-espalhados) da forma e da microestrutura dos agregados das misturas, ativadas mecanicamente por $1 \mathrm{~h}$ e com $1 \%$ de ACP. 
As imagens de MEV (FIG. 14 B) indicam que, ao se aumentar a quantidade de ACP para $2 \%$ em massa, o mesmo mecanismo que atua nas misturas anteriores $(0,5 \mathrm{~h})$ segue ocorrendo, ou seja, a fricção inter-partículas diminui em relação à condição $1 \%$, desfavorecendo a formação de agregados, especialmente no caso da mistura L2, com tamanho médio de partícula de 23,6 $\mu \mathrm{m}$. No caso da L2 a nova quantidade de ACP reduziu bastante a soldagem entre partículas, sendo possível identificar ainda partículas de $\mathrm{Al}$ e $\mathrm{Nb}$ não agregadas. Na mistura L1 os $2 \%$ de ACP foram mais eficientes na redução do tamanho de partícula dos dois pós antes da soldagem, o que fica comprovado pelo resultado da análise de distribuição granulométrica (tamanho médio de partícula de 10,1 $\mu \mathrm{m}$ ). Há também maior aglomeração dos pós (ou dos agregados) por estarem mais finos.

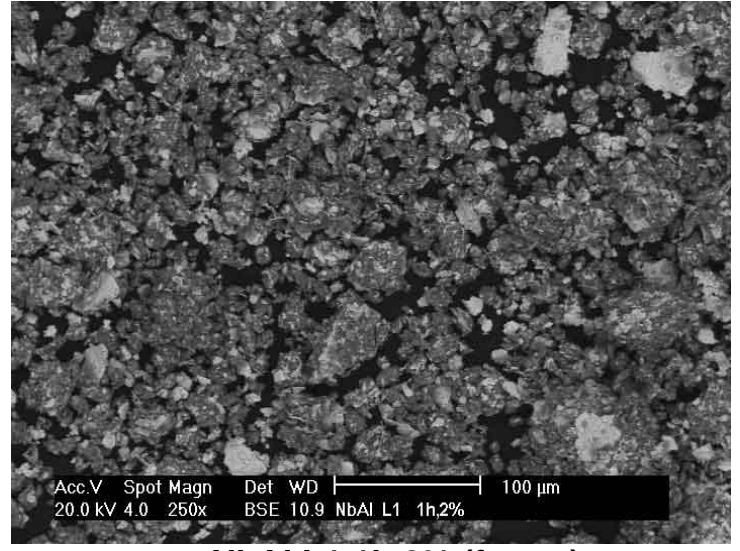

NbAl L1 1h 2\% (forma)

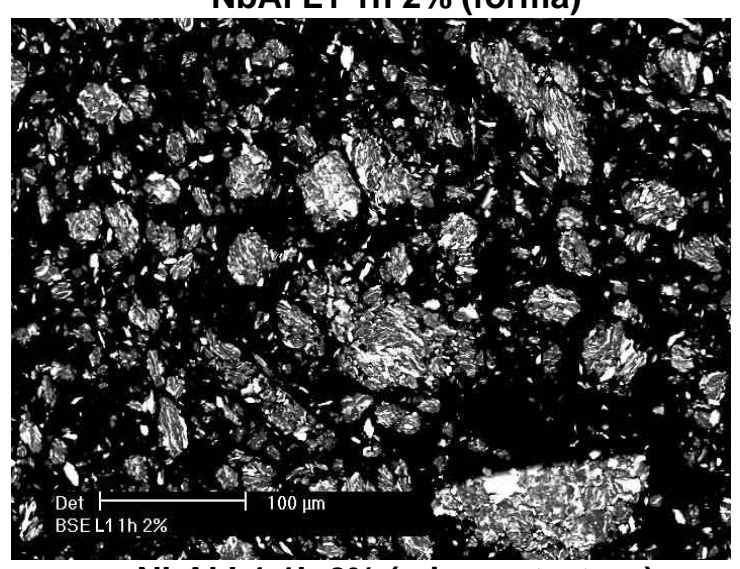

NbAl L1 1h 2\% (microestrutura)

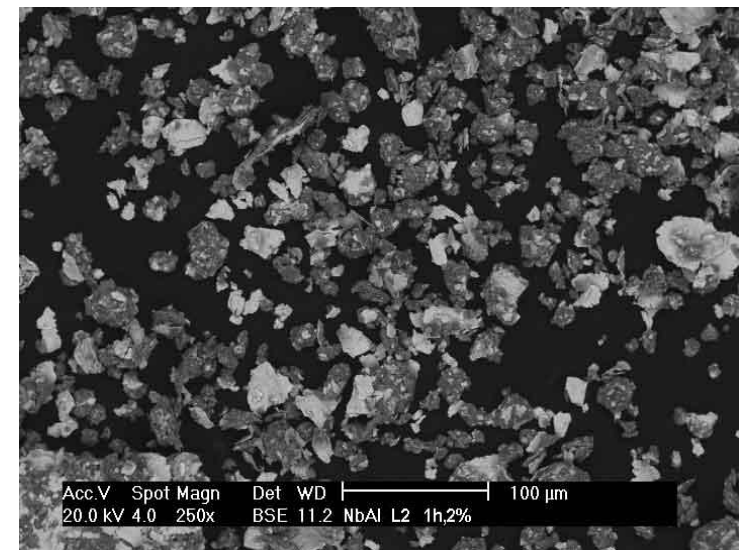

NbAl L2 1 h 2\% (forma)

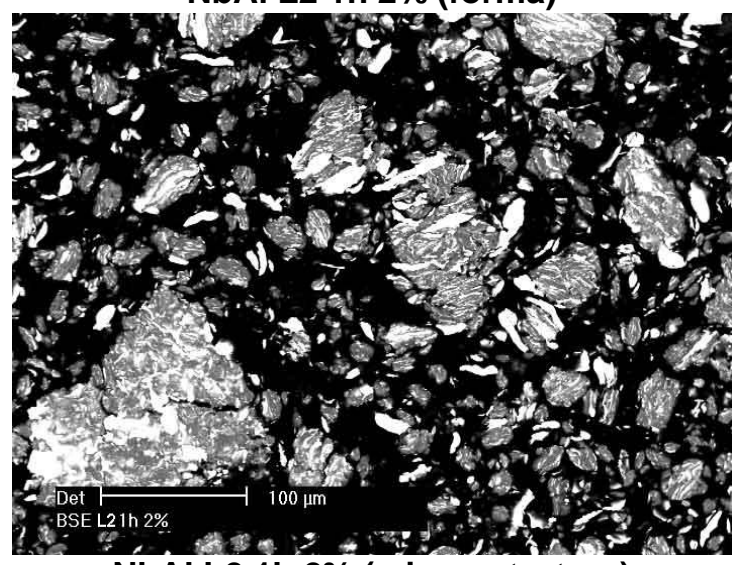

NbAl L2 1h 2\% (microestrutura)

FIGURA 14 B - Micrografias de varredura (imagem de elétrons retro-espalhados) da forma e da microestrutura dos agregados das misturas, ativadas mecanicamente por $1 \mathrm{~h}$ e $2 \%$ de ACP.

Nas FIG. 15 (A e B) e 16 (A e B) encontram-se as distribuições granulométricas das misturas $\mathrm{L} 1 \mathrm{e} \mathrm{L} 2$ ativadas por $1 \mathrm{~h}$, com $1 \%$ e $2 \%$ de ACP, respectivamente. 


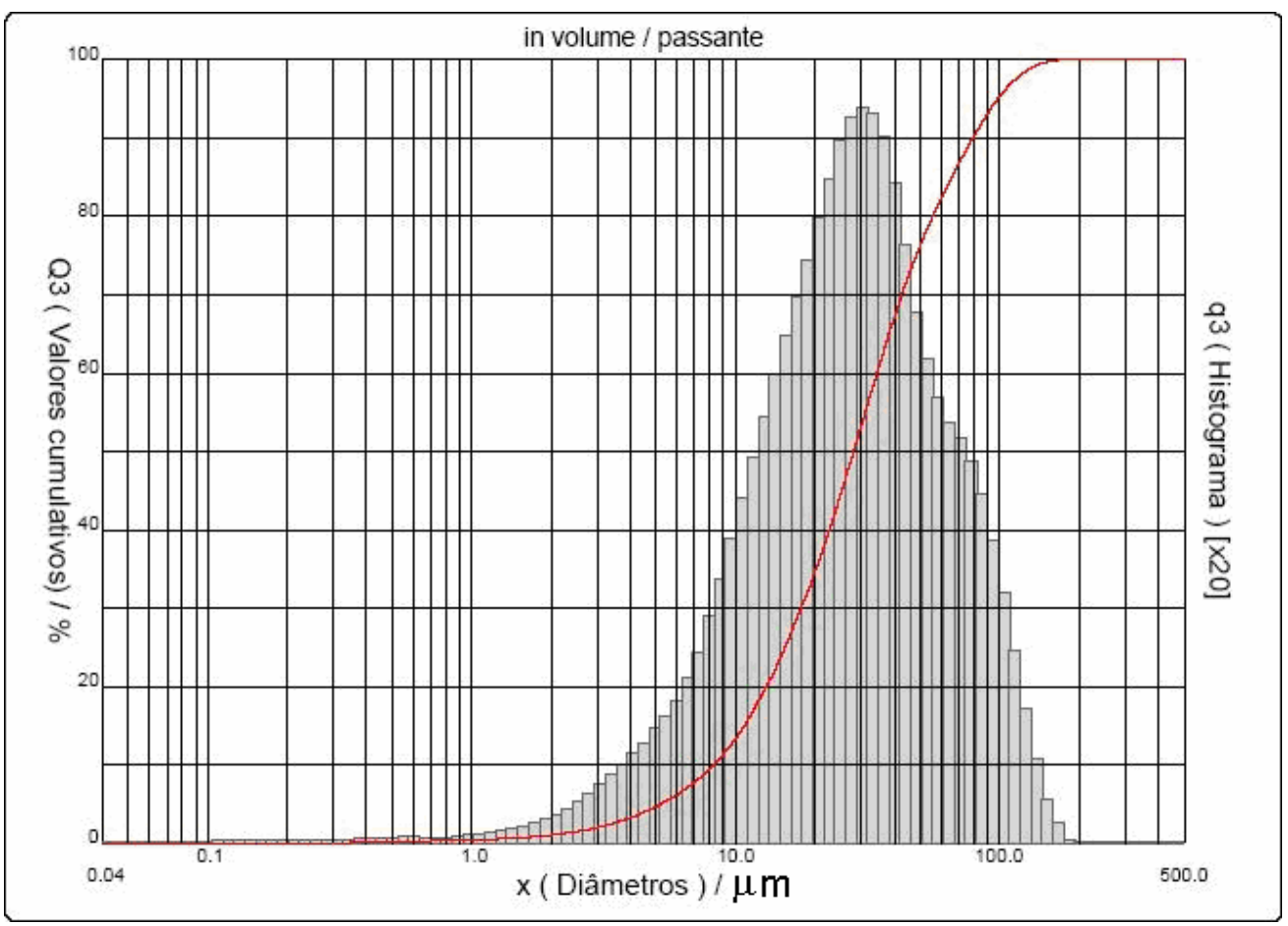

A

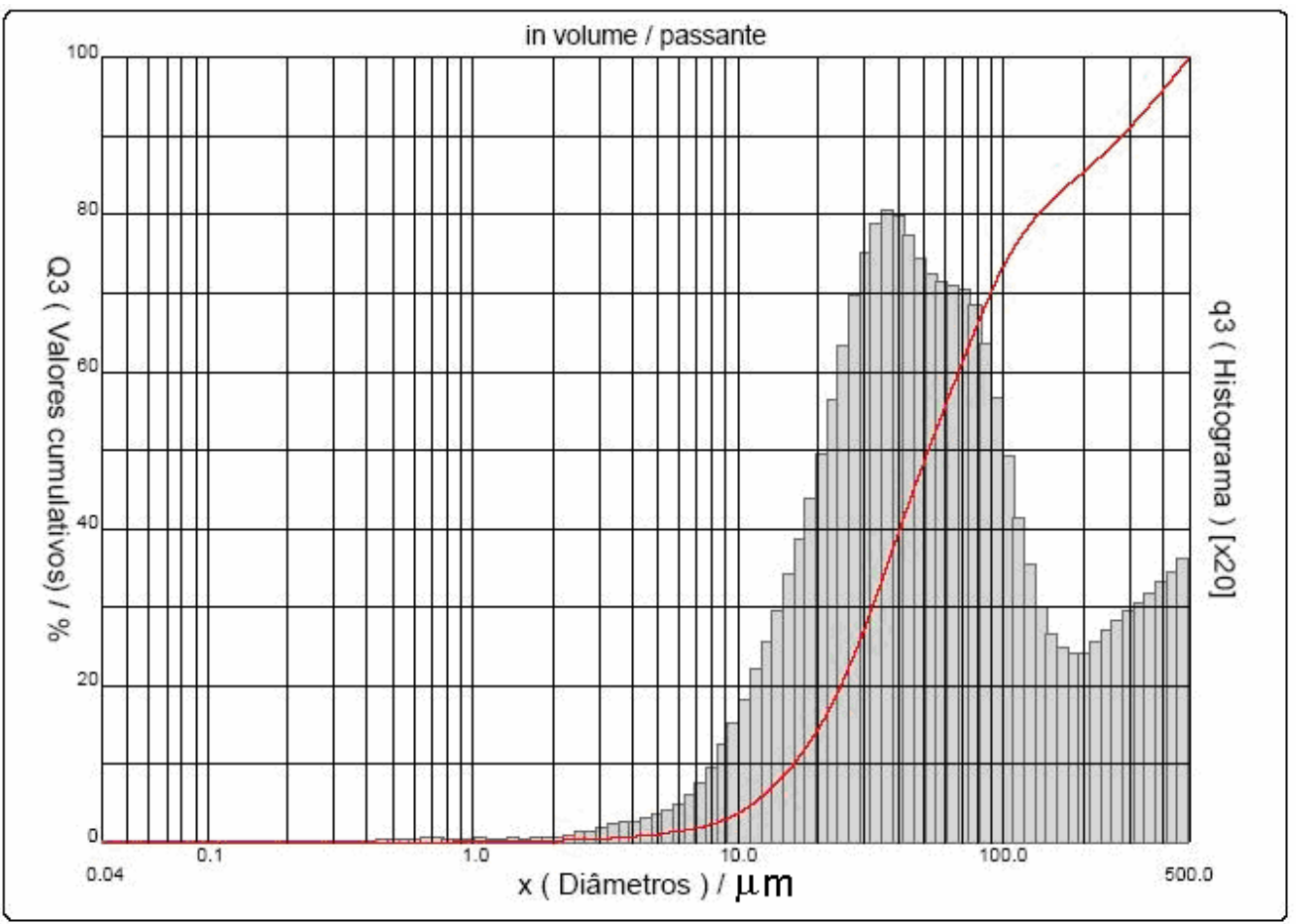

B

FIGURA 15- Distribuição granulométrica das misturas NbAI L1 (A) e NbAI L2 (B) ativadas por $1 \mathrm{~h}$, com $1 \%$ de ACP. A mistura NbAl L2 apresentou agregados maiores que $500 \mu \mathrm{m}$, acima do limite de detecção do equipamento. 

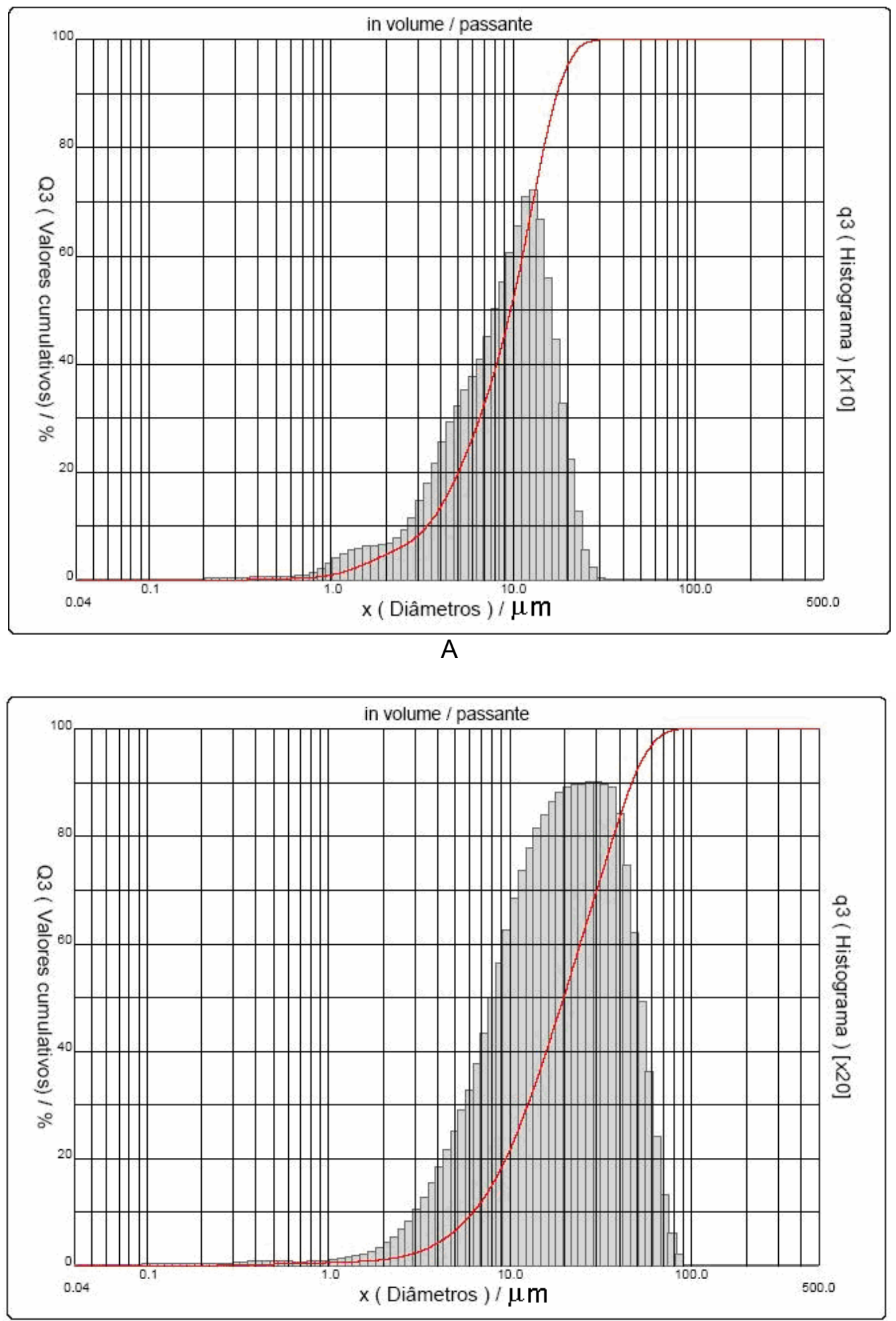

B

FIGURA 16- Distribuição granulométrica das misturas NbAl L1 (A) e NbAL2 (B) ativadas por $1 \mathrm{~h}$, com $2 \%$ de ACP. 
Com 2 horas de moagem e com 1\% em massa de ACP (FIG. 17 A), há uma boa semelhança entre as duas misturas, tanto na forma como no tamanho das partículas/ agregados. Atribuiu-se ao maior tempo de moagem a obtenção de uma maior homogeneização dos agregados, certamente mais encruados que na condição de moagem por 1 hora. O ciclo deformação-soldagem-fratura provavelmente está mais próximo da estabilidade de forma que os agregados formados são, de maneira geral, mais homogêneos e pequenos $(<50 \mu \mathrm{m})$, devido à perda de ductilidade, o que também desfavorece a soldagem.
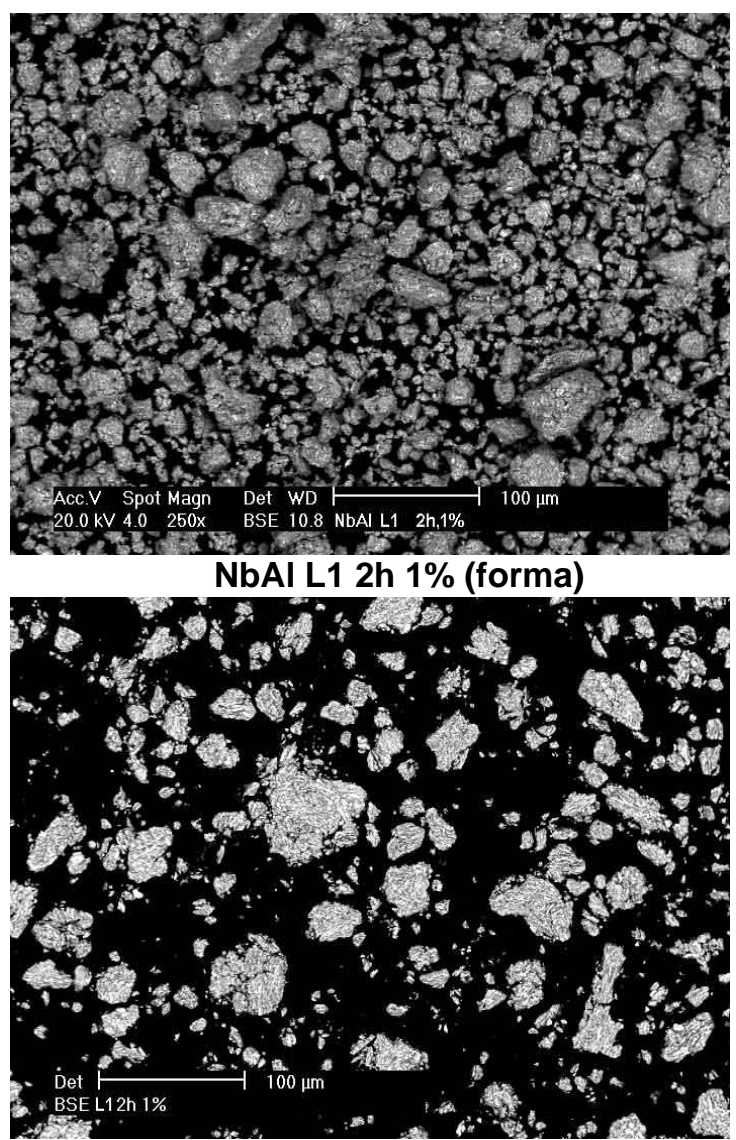

NbAl L1 2h 1\% (microestrutura)

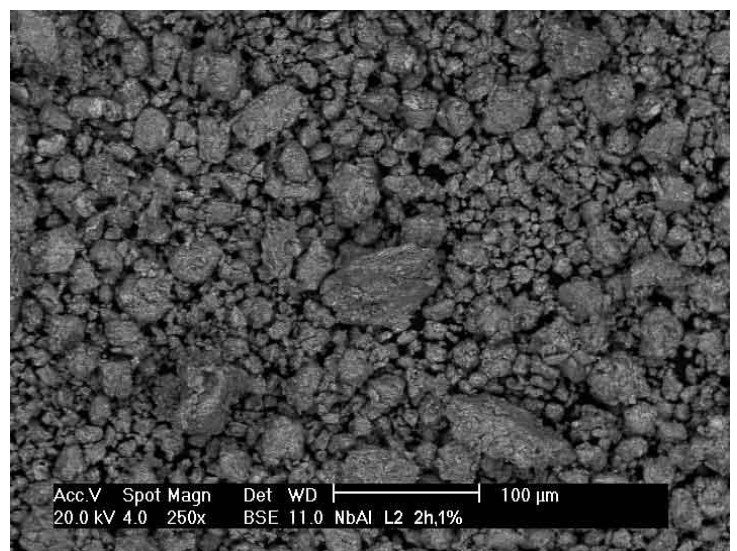

NbAI L2 2h 1\% (forma)

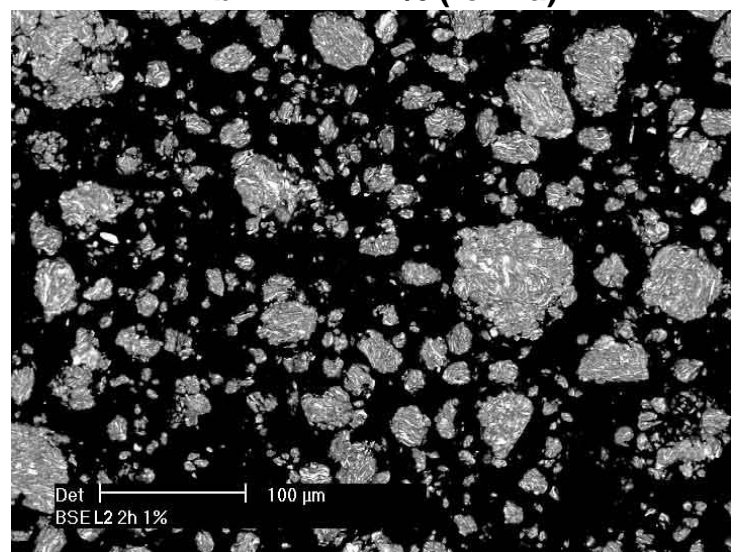

NbAI L2 2h 1\% (microestrutura)

FIGURA 17 A - Micrografias de varredura (imagem de elétrons retro-espalhados) da forma e da microestrutura dos agregados das misturas, ativadas mecanicamente por $2 \mathrm{~h}$ com $1 \%$ de ACP. 


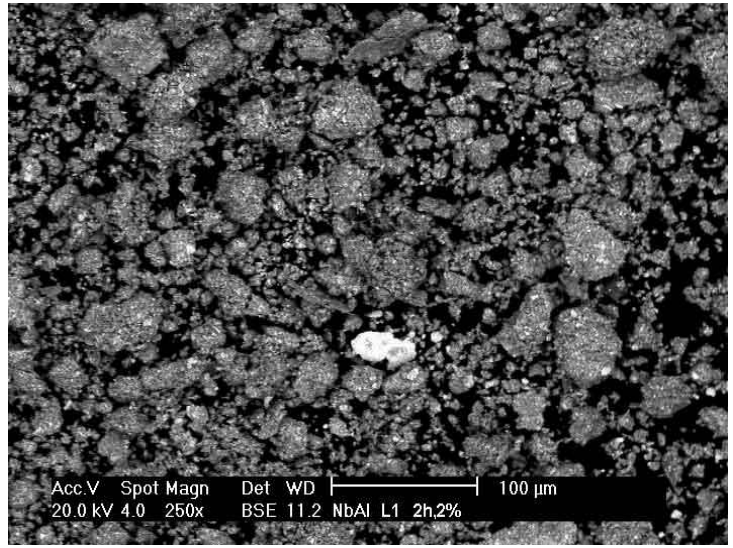

NbAI L1 2h 2\% (forma)

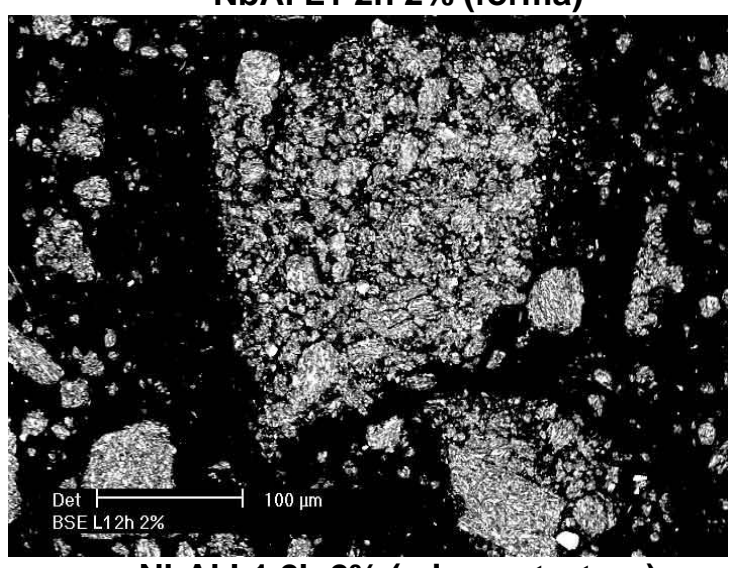

NbAl L1 2h 2\% (microestrutura)

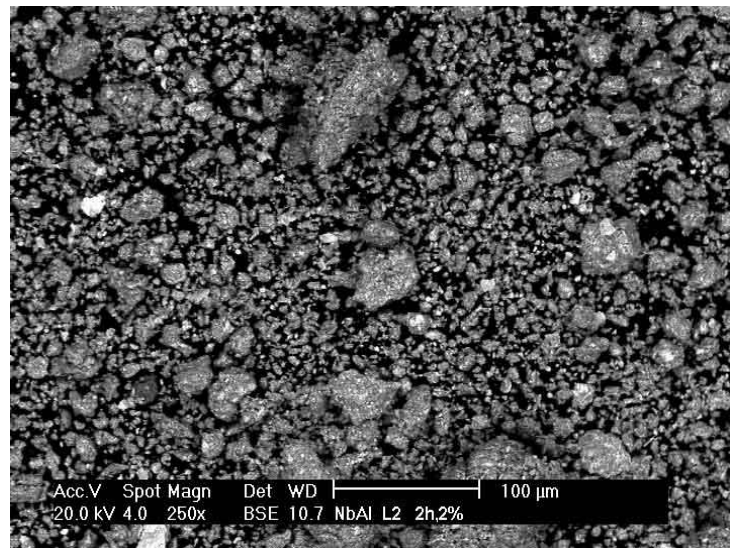

$\mathrm{NbAl}$ L2 2h 2\% (forma)

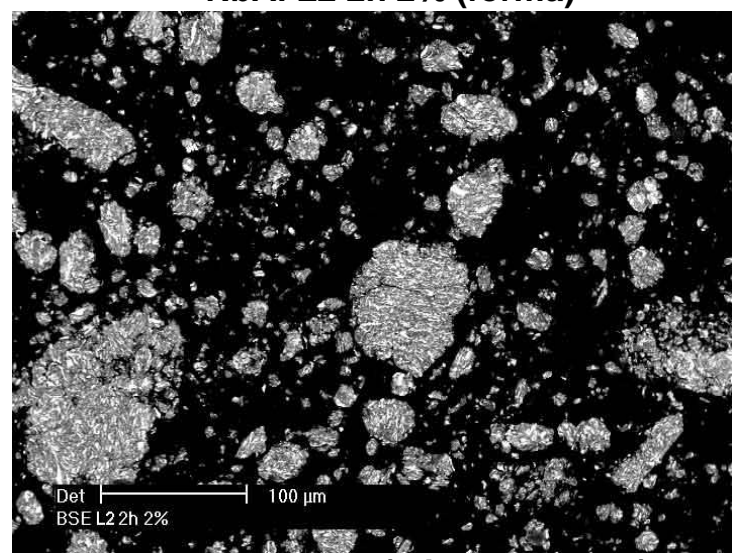

NbAl L2 2h 2\% (microestrutura)

FIGURA 17 B- Micrografias de varredura (imagem de elétrons retro-espalhados) da forma e da microestrutura dos agregados das misturas, ativadas mecanicamente por 2 h e $2 \%$ de ACP.

Com o aumento da quantidade de ACP para $2 \%$ (fig.17 B), o que se observa em destaque são partículas isoladas de $\mathrm{Nb}$, indicando que o aumento da quantidade de ACP provocou um retardamento na formação de agregados.

Nas figuras 18 (A e B) são apresentadas as distribuições granulométricas das misturas $L 1$ e $L 2$ com $2 h$ de ativação e 1\% de ACP, e nas FIG. 19 (A e B) idem, com $2 \%$ de ACP. 


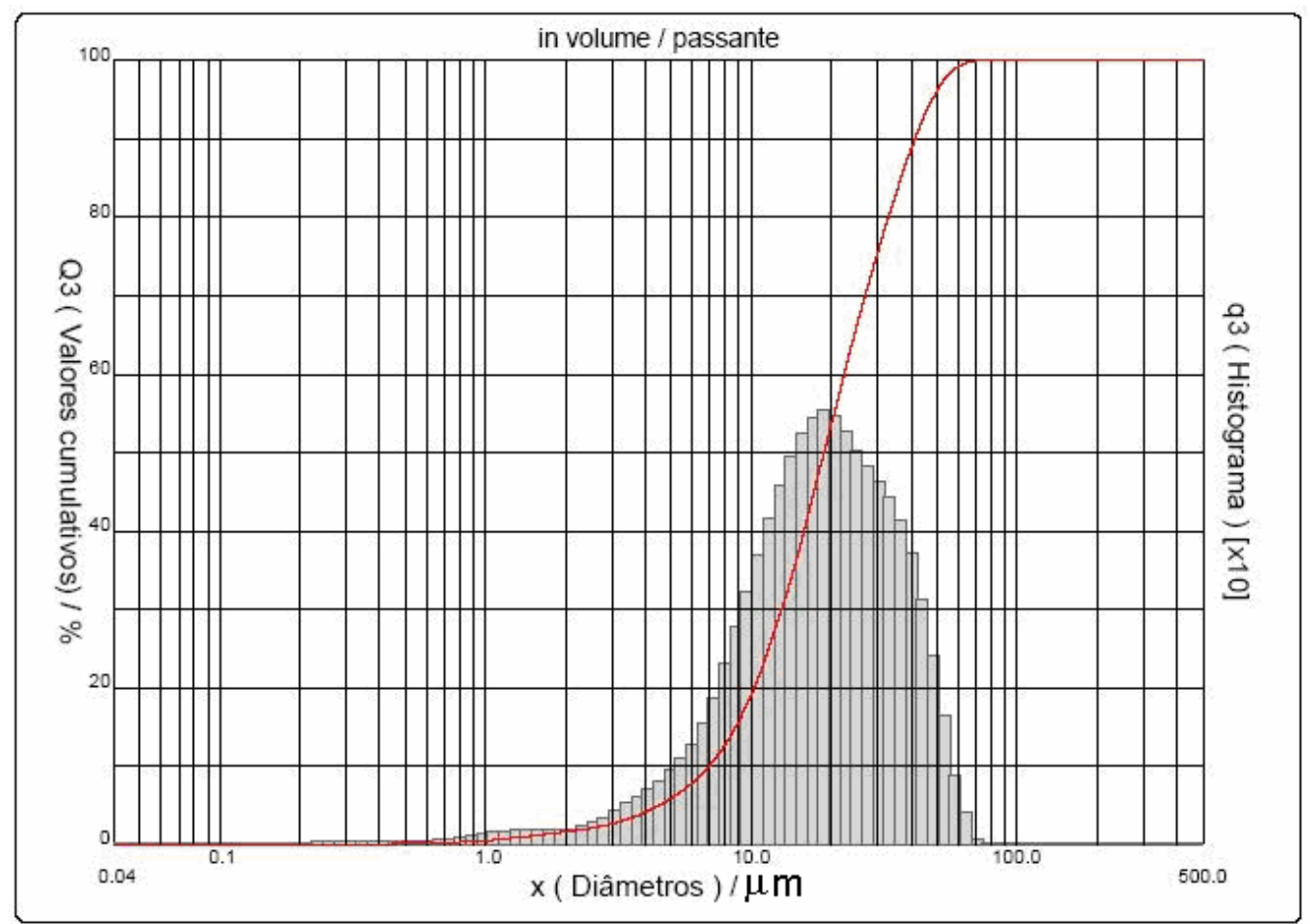

A

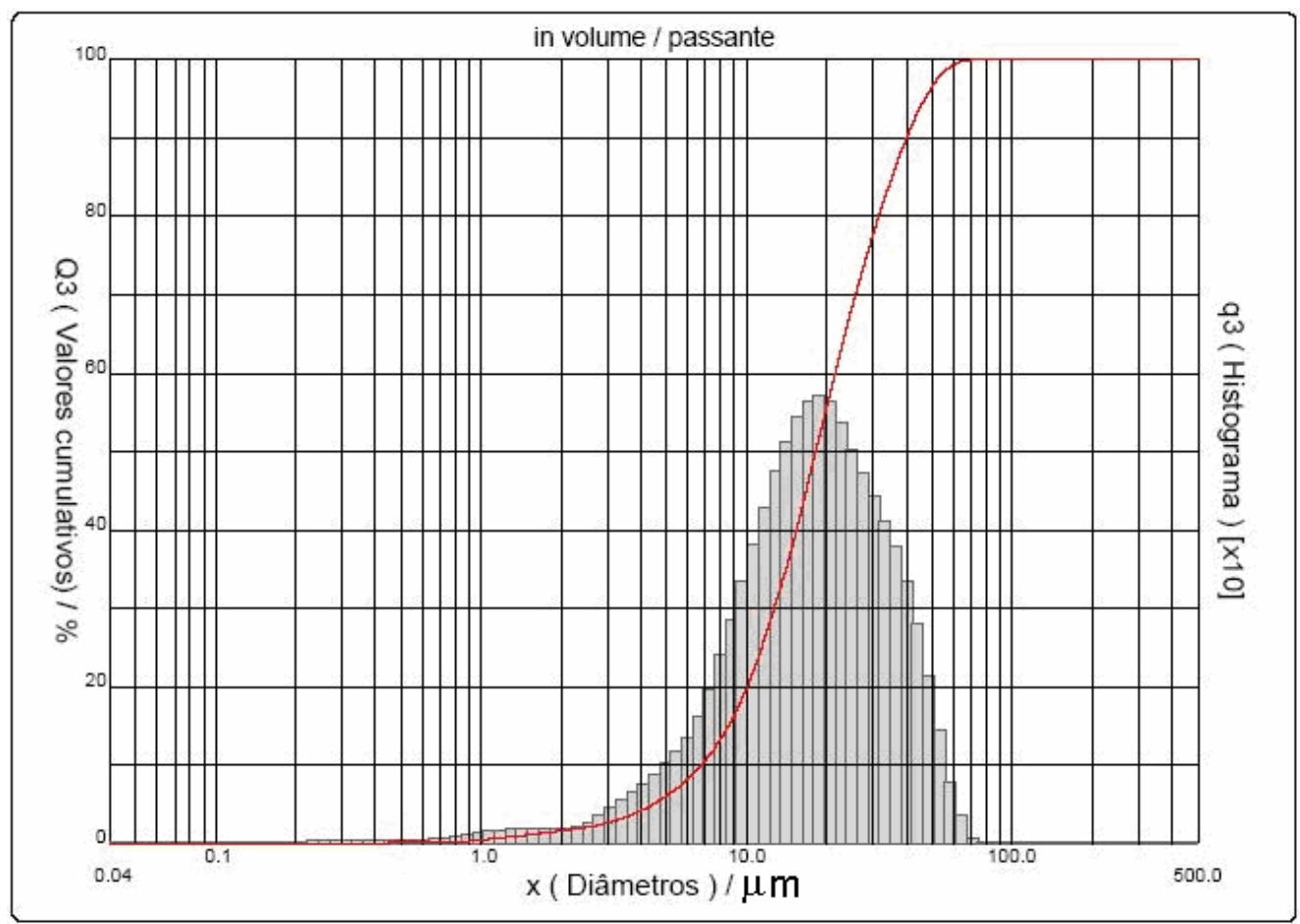

B

FIGURA 18- Distribuição granulométrica das misturas NbAl L1 (A) e NbAL2 (B) ativadas por 2 horas, com $1 \%$ de ACP. 


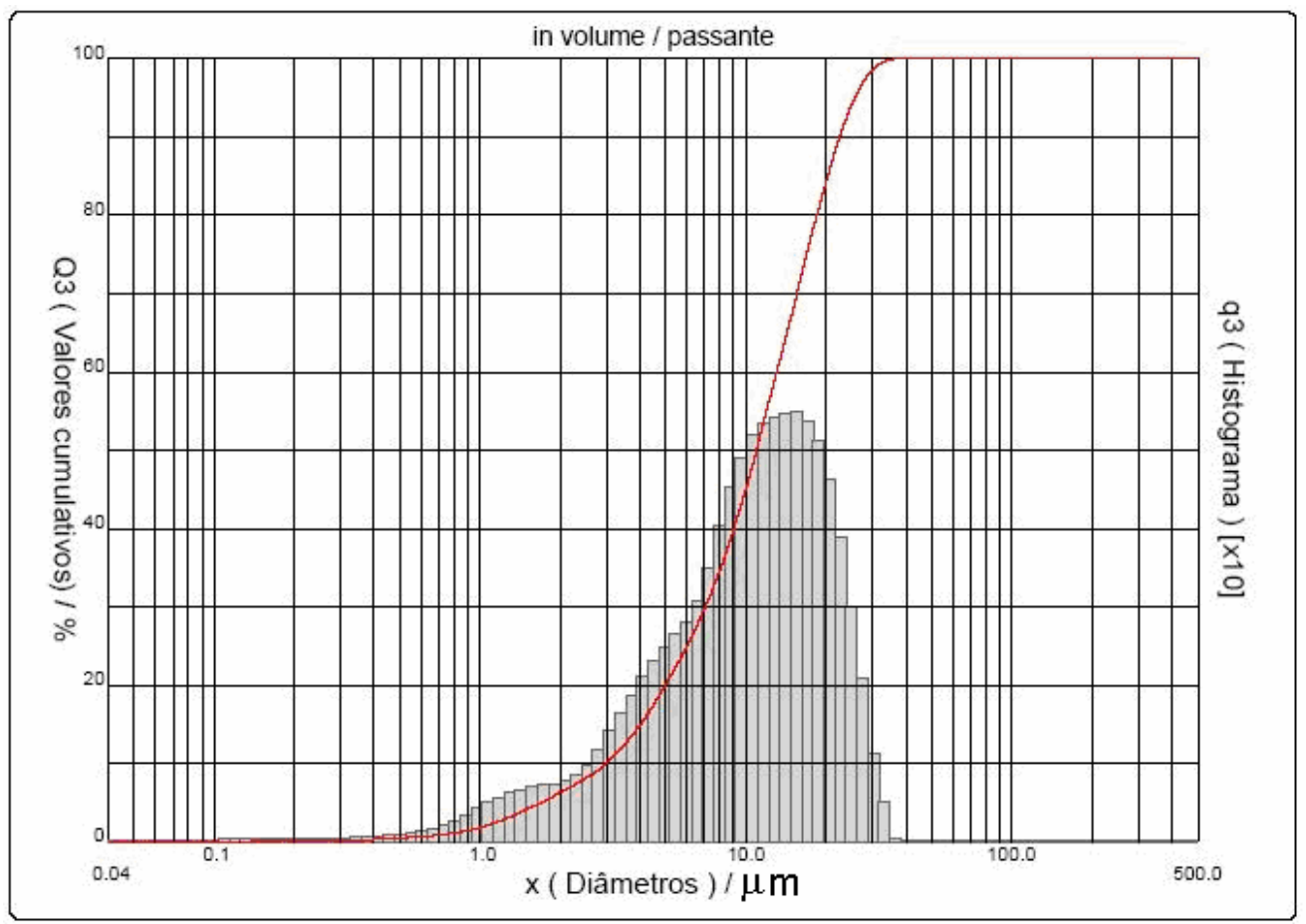

A

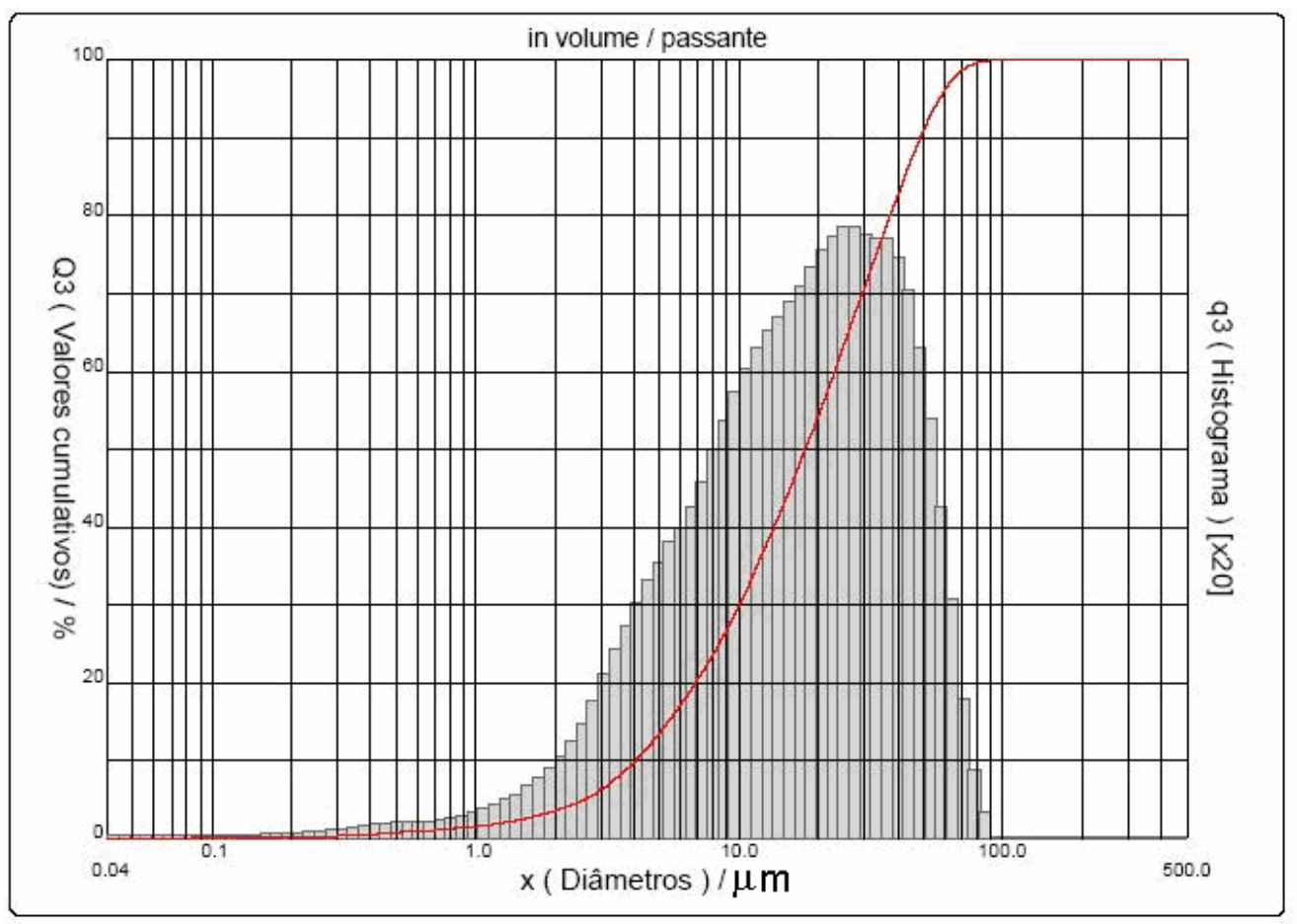

B

FIGURA 19- Distribuição granulométrica das misturas NbAI L1 (A) e NbAL2 (B) ativadas por 2 horas, com $2 \%$ de ACP. 
Para se ter uma idéia do quanto com 2 horas o ciclo deformação-fratura está próximo da estabilidade, foram feitas duas misturas com 2,5 horas de ativação mecânica: L1 e L2 com 1\% ACP.

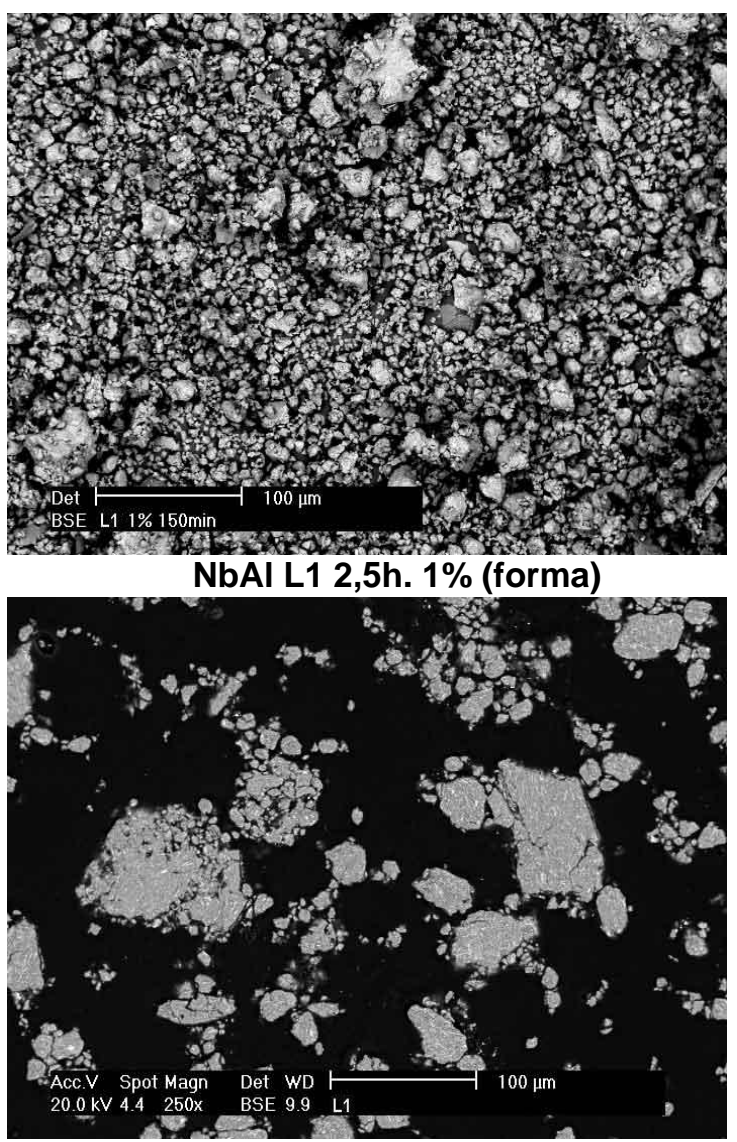

NbAl L1 2,5h. 1\% (microestrutura)
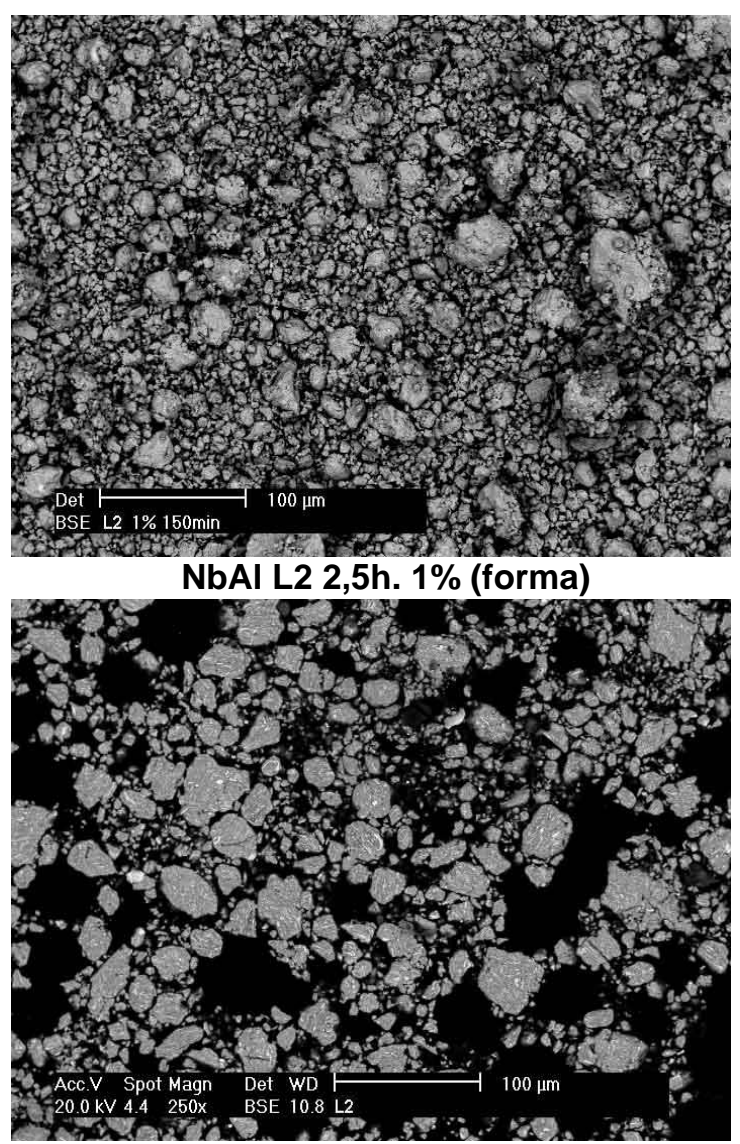

NbAl L2 2,5h. 1\% (microestrutura)

FIGURA 20 - Micrografias de varredura (imagem de elétrons retro-espalhados) da forma e da microestrutura dos agregados das misturas L1 e L2 ativadas mecanicamente por $2,5 \mathrm{~h}$.

Como resultado, obteve-se algo muito próximo à condição das mesmas misturas com 2 horas de ativação, com pequena variação nos tamanhos médios de partícula. Com o aumento gradativo dos tempos de ativação, as amostras L2 e L1 tendem a ficar morfologicamente idênticas, além de haver aumento da homogeneização (FIG.20). Na FIG.21 são mostrados os histogramas de distribuição granulométrica das amostras ativadas por 2,5 horas com 1\% de ACP. 


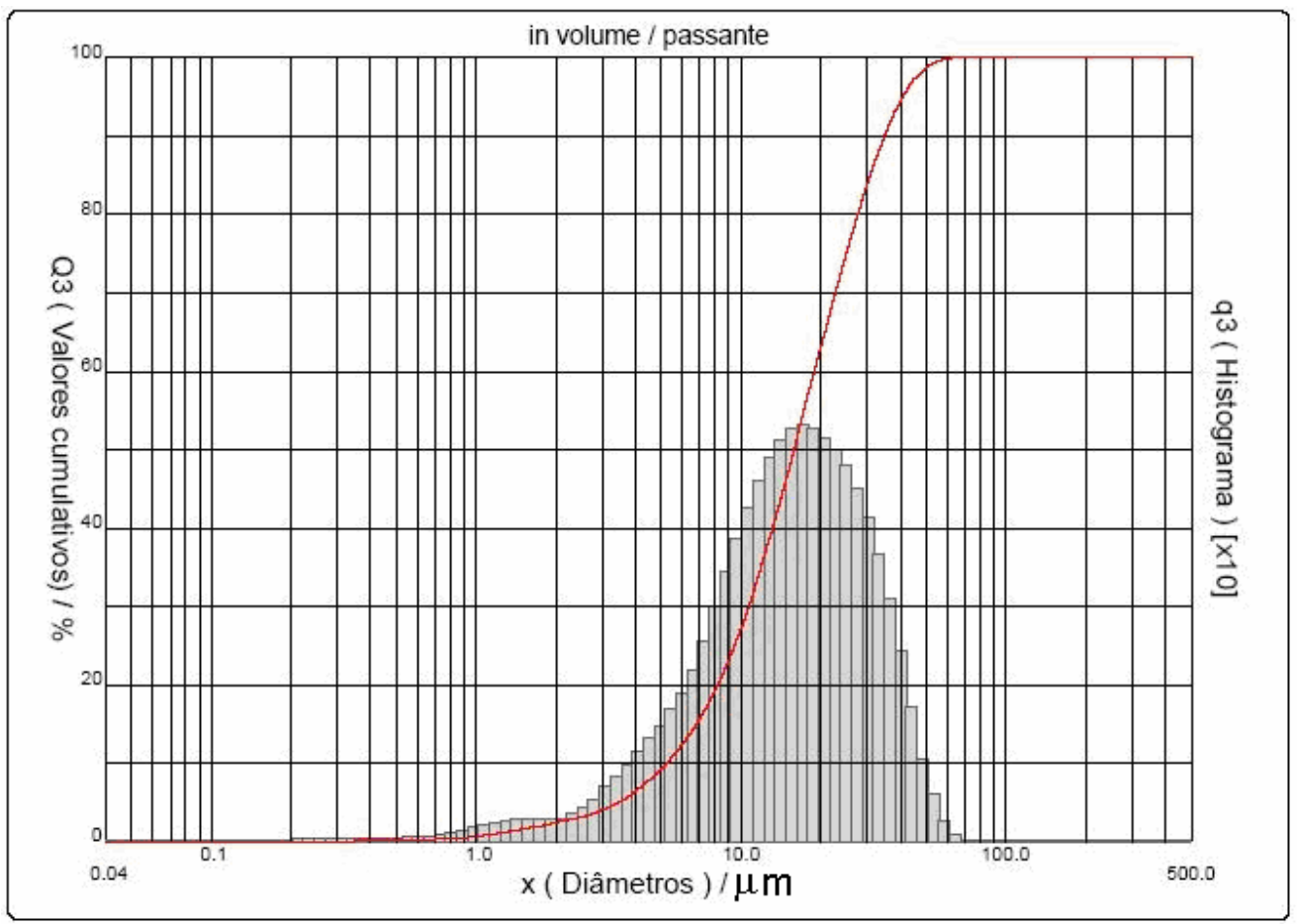

A

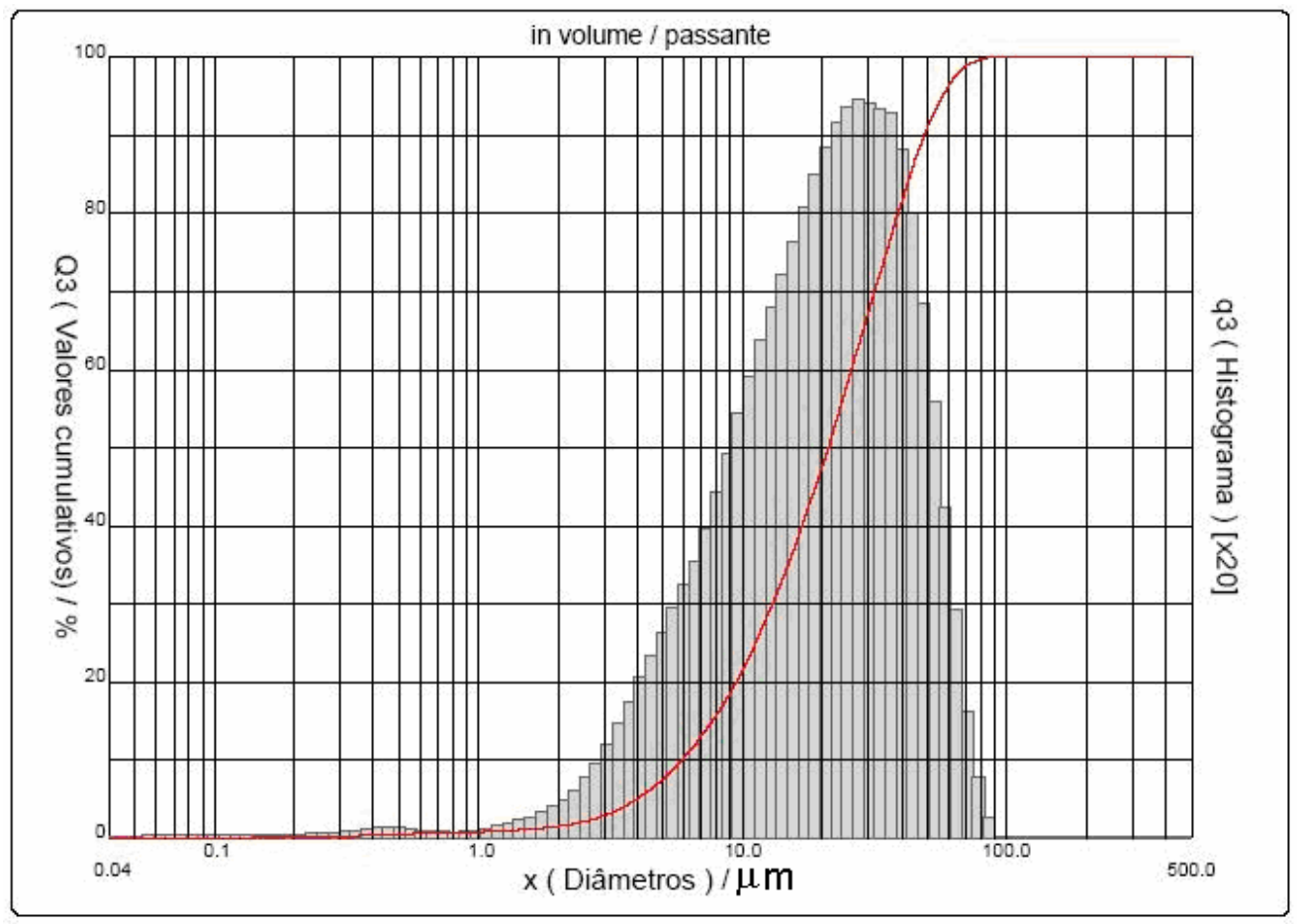

B

FIGURA 21- Distribuição granulométrica das misturas NbAI L1 (A) e NbAL2 (B) ativadas por $2,5 \mathrm{~h}$, com $1 \%$ de ACP. 
Para verificar se houve ou não formação de fases intermetálicas durante a ativação mecânica, foi feito um difratograma de raios $X$ da mistura $L 2$ ativada por 2,5 horas com 1\% de ACP (FIG.22), ou seja, condição de maior tempo de moagem e menor quantidade de ACP.

Os picos encontrados são referentes somente ao alumínio e ao nióbio na mistura não havendo, portanto, formação de novas fases.

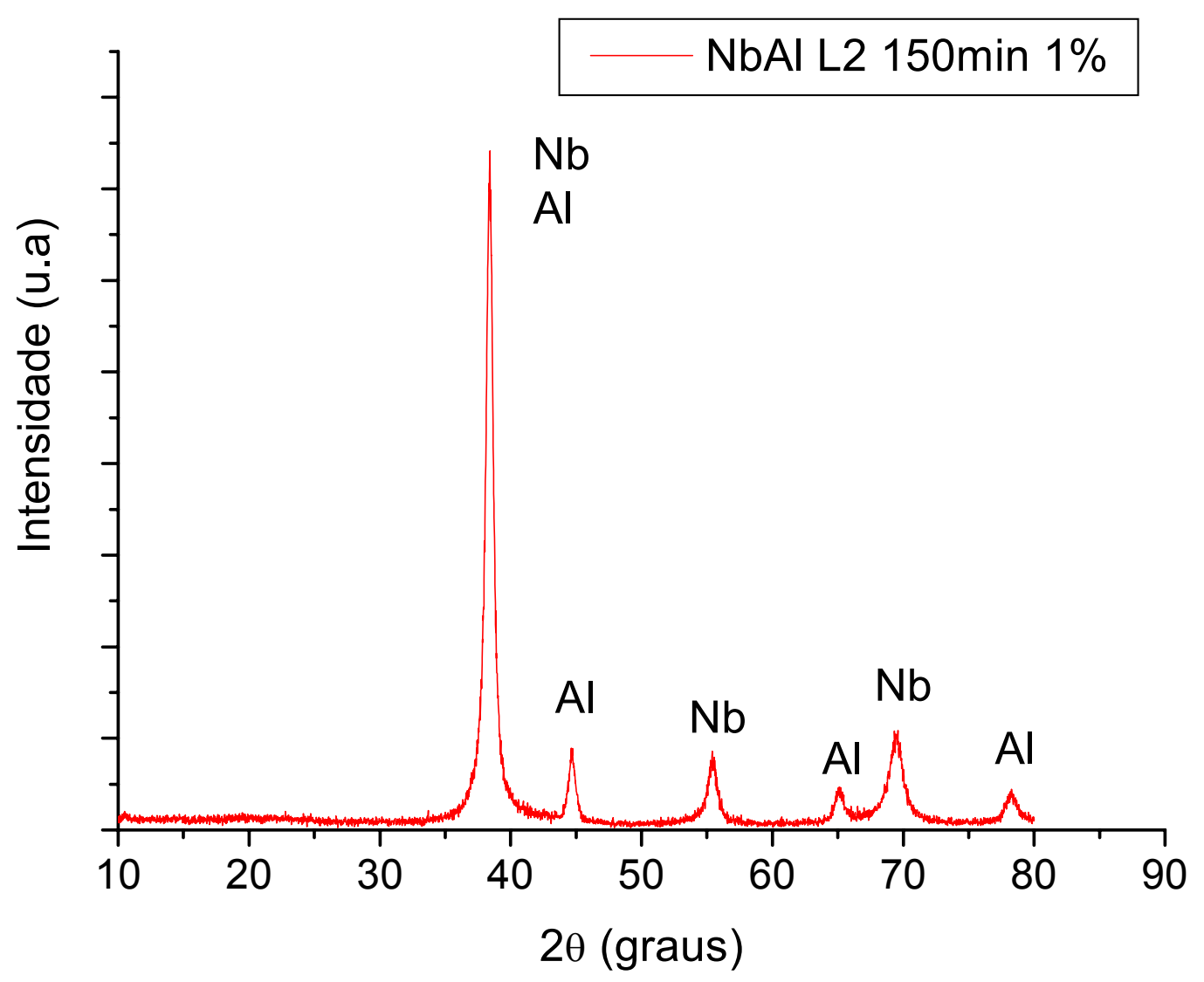

FIG 22- Difratograma de raios $X$ da mistura $L 2$ ativada por 2,5 horas e $1 \%$ de ACP, mostrando que não houve a formação de fase intermetálica durante o processo de moagem. 


\subsubsection{Curvas de compressibilidade}

Na FIG. 23 são apresentadas as curvas de compressibilidade das misturas ativadas por 0,5h e $1 \mathrm{~h}$. As curvas de compressibilidade das amostras ativadas por $1 \mathrm{~h}$ com 1\% ACP foram as primeiros a serem realizadas e por isso servirão como padrão de comparação inicial com as outras condições (FIG. 23C). Nota-se que nesta condição a mistura $\mathrm{Nb}-\mathrm{Al}$ L2 tem compressibilidade pouco mais alta que a $\mathrm{Nb}-\mathrm{Al} \mathrm{L} 1$, com densidades relativas máximas de 0,812 e 0,791 , respectivamente. $\mathrm{A}$ mistura L2, por apresentar uma distribuição de tamanho de agregados mais estreita que a L1 possui um empacotamento menor. Isto favorece a compressibilidade em razão do elevado volume de espaços vazios entre as partículas, ao passo que a L1, com maior grau de empacotamento em virtude da diversidade de tamanhos, tem sua compressibilidade diminuída, pois também é maior o atrito entre os agregados, a ser vencido durante a compactação.

É importante observar que, em razão da proporção Nb/Al utilizada, o Al está presente em maior volume que o $\mathrm{Nb}$ (em cada pastilha de $4 \mathrm{~g}$ os volumes de $\mathrm{Al} \mathrm{e}$ $\mathrm{Nb}$ são $0,687 \mathrm{~cm}^{3}$ e $0,250 \mathrm{~cm}^{3}$, respectivamente). Sendo assim, as partículas de Al vão envolvendo as partículas de $\mathrm{Nb}$, ao longo da moagem, formando um "colchão" que amortece o impacto das bolas de moagem com o $\mathrm{Nb}$, limitando o encruamento das partículas do mesmo, pelo menos até certo estágio do processo. A amostra L2 estaria menos encruada (como visto no item 4.1.1) e, portanto, mais susceptível à densificação que a amostra L1.

Para tempos de moagem de 0,5 h (FIG. 23 A e B), verificou-se nas amostras $\mathrm{NbAl}$ L2 a maior densificação dentre todas as amostras, o que pode ser atribuído ao menor encruamento em relação às demais condições, aliado ao fato que o alumínio desta mistura é inicialmente mais mole que o alumínio da mistura NbAl L1. No caso da mistura $\mathrm{NbAl}$ L2 feita com 1\% de ACP, têm-se, observando-se as micrografias, os maiores agregados, elevado volume de espaços vazios e, portanto, alta densificação, com densidade relativa máxima de 0,866 . No caso da mesma mistura com $2 \%$ nota-se também alta densificação (densidade relativa máxima de 0,864), indicando que houve realmente pouco encruamento, embora com o aumento da quantidade de ACP tenha ocorrido uma diminuição do tamanho dos agregados em virtude da pouca soldagem. Isto explica o porquê da formação de alguns agregados, mas especialmente a elevada aglomeração. As amostras L1 
têm grau de encruamento inicial maior que as $L 2$, obtendo-se densidades relativas máximas de 0,792 ( $1 \%$ de ACP) e 0,782 (2\% de ACP).

O tempo de $1 \mathrm{~h}$ de ativação não foi suficiente para reduzir consideravelmente a compressibilidade da amostra L1 em relação à mesma amostra ativada por $0,5 \mathrm{~h}$ com $1 \%$ de ACP. Para a amostra L1 com $2 \%$ de ACP, no entanto, a densidade relativa caiu para 0,768 , com $1 \mathrm{~h}$ de ativação.

Aumentando-se a quantidade de ACP para $2 \%$ e mantendo-se o mesmo tempo da condição anterior (1 h) (FIG.23 D), nota-se primeiramente uma ligeira queda na compressibilidade de ambas as misturas. As densidades relativas caem para 0,786 (L2) e 0,768 (L1), queda associada ao menor tamanho das partículas/ agregados (o efeito "colchão" é bem menos acentuado com $2 \%$ de ACP).
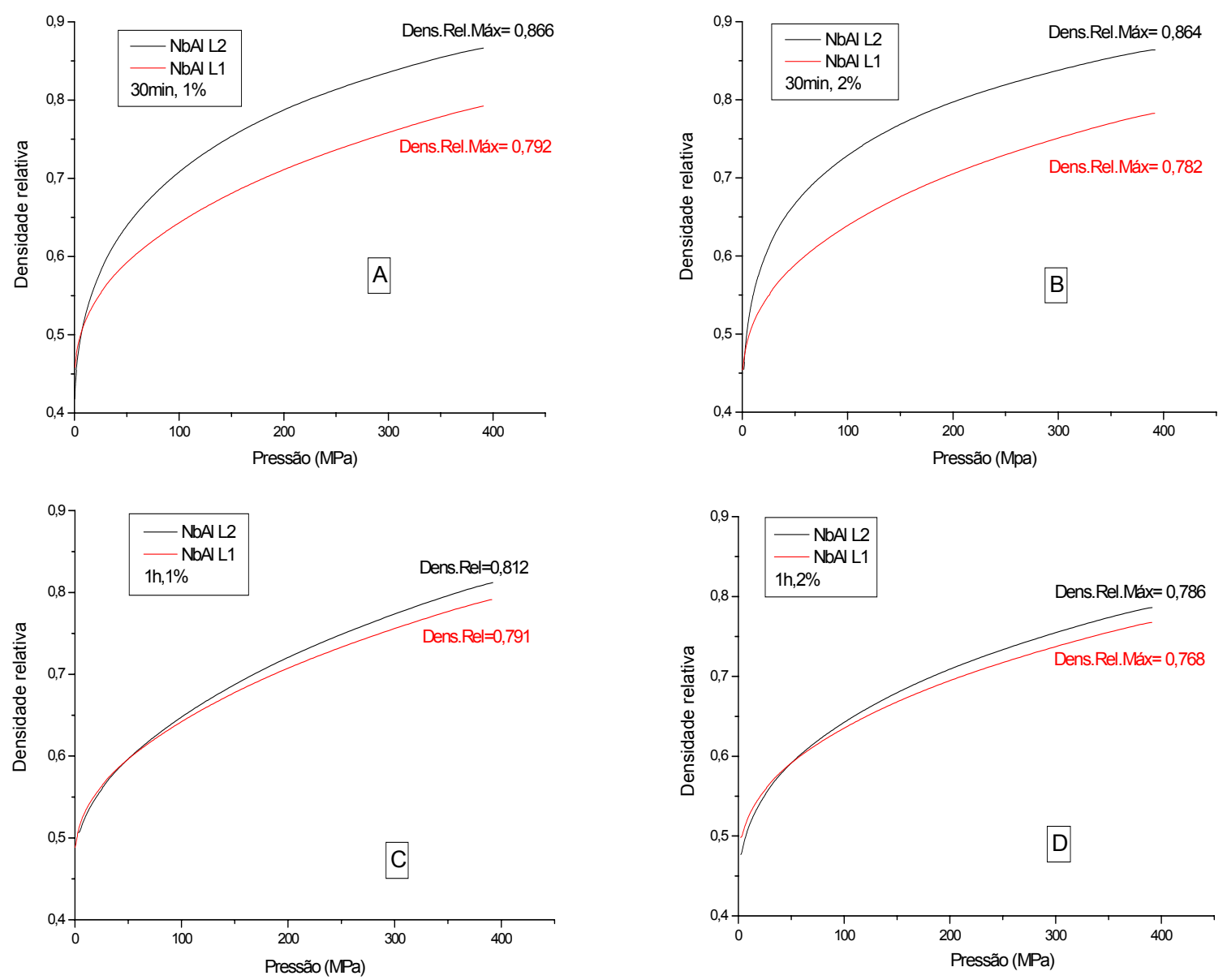

Figura 23- Curvas de compressibilidade (densidade relativa $\mathrm{x}$ pressão) das amostras ativadas por $0,5 \mathrm{~h}$ com $1 \%$ de ACP (A) e $2 \%$ de ACP (B), e por $1 \mathrm{~h}$ com $1 \%$ de ACP (C) e $2 \%$ de ACP (D). 
Aumentando-se o tempo de moagem para $2 \mathrm{~h}$, mas mantendo-se a quantidade de ACP idêntica à condição inicial padrão (1\%), observa-se pelo gráfico do ensaio de compactação (FIG. 24 E) que a densificação das duas misturas L2 e L1 é muito semelhante, com densidades relativas no final do ensaio de 0,731 e 0,727 , respectivamente, as menores observadas entre todos os ensaios realizados. A semelhança de resultados é devida à semelhança de forma e tamanho discutida anteriormente, na apresentação das micrografias de varredura. A diferença apenas marginal na densificação entre as misturas L2 e L1 é devida a erros de repetitibilidade inerentes ao procedimento de compactação, visto que o tamanho médio de partícula das duas misturas é praticamente o mesmo $(21,1 \mu \mathrm{m}$ e $21,7 \mu \mathrm{m}$, respectivamente).
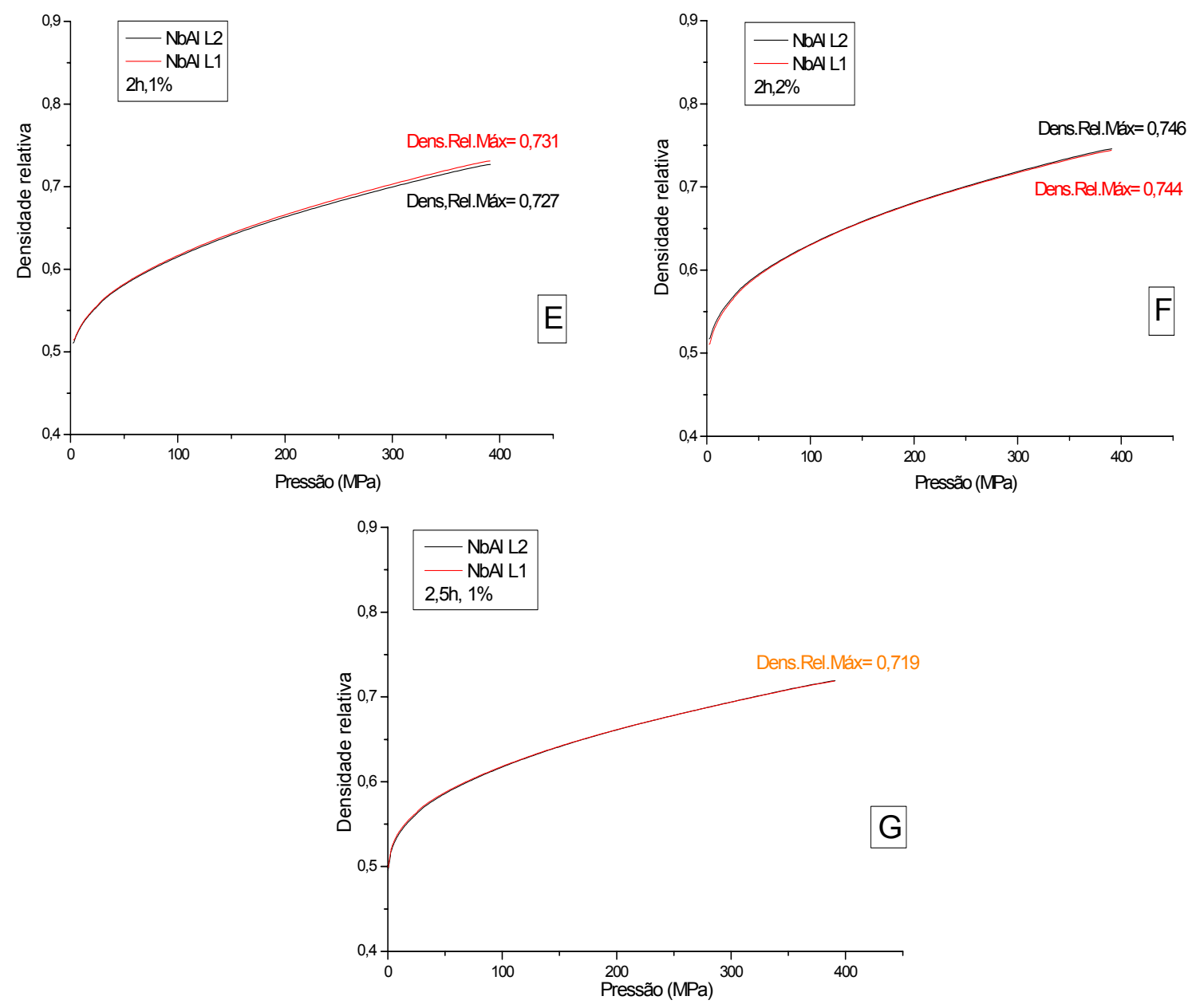

Figura 24- Curvas de compressibilidade (densidade relativa $\mathrm{x}$ pressão) das amostras ativadas por $2 \mathrm{~h}$ com $1 \%$ de ACP $(E)$, com $2 \%$ de ACP $(F)$ e por $2,5 \mathrm{~h}$ com $1 \%$ de ACP $(G)$. 
As curvas de compactação das duas misturas (L2 e L1) com 2 horas de moagem e com $2 \%$ em massa de ACP são praticamente idênticas em toda sua extensão (FIG. 24 F). Existe uma acentuada queda na densificação destas misturas em relação às duas condições iniciais, embora que quando comparadas com a condição anterior ( $2 \mathrm{~h}, 1 \%)$, estas moagens $(2 \mathrm{~h}, 2 \%)$ tenham resultado em densificação um pouco maior. A melhor densificação em relação às misturas moídas com $1 \%$ de ACP pode ser atribuída à ação lubrificante do ácido esteárico.

As compactações realizadas com tempos maiores $(2,5 \mathrm{~h})$ para as amostras com $1 \%$ de ACP (FIG.24 G) permitem verificar que há uma lógica entre o comportamento das amostras sob compactação: com o aumento gradativo dos tempos de ativação, os gráficos sobrepostos as curvas de compressibilidade das amostras L1 e L2 tendem a aproximar-se, além de haver diminuição no valor da densificação final.

Obviamente, a deformação plástica de um agregado de dois materiais, sob impacto de bolas, não é um fenômeno simples. O encruamento (pré- ativação) do pó de $\mathrm{Nb}$ altera a microestrutura dos agregados obtidos na moagem com alta energia, indo de lamelar ( $\mathrm{Nb}$ não encruado) a uma dispersão de partículas globulares ( $\mathrm{Nb}$ encruado) na matriz de alumínio. O mecanismo preponderante de ativação mecânica por moagem com alta energia de misturas $\mathrm{Nb}_{25} \mathrm{Al}_{75}$ é o aumento da área de interface entre o alumínio e o nióbio ${ }^{[56]}$. 


\subsection{Equações de compactação}

Analisando-se as equações apresentadas anteriormente na revisão bibliográfica, nota-se que todas elas podem ser descritas pela equação geral de uma reta. Para a equação de Kawakita e Lüdde, é válida a eq. 10, em que $A=1 / a$ e $B=1 / a b$. Para as demais, é válida a eq. 11, conforme abaixo:

$$
\begin{aligned}
& f(P, V)=A P+B \\
& f(D)=A f(P)+B
\end{aligned}
$$

Para efeito de clareza, as equações levantadas na literatura são apresentadas na TAB. 5 juntamente com com as expressões explícitas de $f(P, V)$ ) e $f(P)$ para a equação de Kawakita e Lüdde e $f(D)$ e $f(P)$ (demais equações).

TABELA 5 - Expressões de $f(D)$ (ou $f(P, V)$, para a eq. de Kawakita e Lüdde) e

\begin{tabular}{|c|c|c|c|}
\hline Autores & Equação & $f(\mathrm{D})$ ou $f(\mathrm{P}, \mathrm{V})$ & $f(\mathrm{P})$ \\
\hline Balshin & $\ln P=-\frac{A_{1}}{D}+B_{1}$ & $\frac{1}{\mathrm{D}}$ & $\ln \mathrm{P}$ \\
\hline Heckel & $\ln \left(\frac{1}{1-\mathrm{D}}\right)=\mathrm{A}_{2} \mathrm{P}+\mathrm{B}_{2}$ & $\ln \left(\frac{1}{1-\mathrm{D}}\right)$ & $P$ \\
\hline Kawakita \& Lüdde & $\frac{P}{C}=\frac{P}{a}+\frac{1}{a b}$ com $C=\frac{V_{0}-V}{V_{0}}$ & $\frac{\mathrm{P}}{\left(\frac{\mathrm{V}_{0}-\mathrm{V}}{\mathrm{V}_{0}}\right)}$ & $P$ \\
\hline $\mathrm{Ge}$ & $\log \left(\ln \frac{1}{(1-D)}\right)=A_{3} \log P+B_{3}$ & $\log \left(\ln \frac{1}{(1-\mathrm{D})}\right)$ & $\log \mathrm{P}$ \\
\hline $\begin{array}{c}\text { Panelli \& } \\
\text { Ambrozio Filho }\end{array}$ & $\ln \left(\frac{1}{1-D}\right)=A_{4} \sqrt{P}+B_{4}$ & $\ln \left(\frac{1}{1-\mathrm{D}}\right)$ & $\sqrt{P}$ \\
\hline $\begin{array}{l}\text { Castagnet \& } \\
\text { Leal Neto * }\end{array}$ & $\ln \left(\frac{1}{1-D}\right)=A_{5} P^{0,6}+B_{5}$ & $\ln \left(\frac{1}{1-\mathrm{D}}\right)$ & $P^{0,6}$ \\
\hline
\end{tabular}
$f(P)$ das equações de compactação encontradas na literatura. 
Nestas equações, o parâmetro $\boldsymbol{A}$ (coeficiente angular da reta) fornece a capacidade de deformação plástica das partículas durante a compactação. Assim, quanto maior $\boldsymbol{A}$, maior é a capacidade de deformação do pó. O parâmetro $\boldsymbol{B}$ indica a densidade relativa do pó na menor pressão aplicada. Como dito anteriormente, o parâmetro $\boldsymbol{B}$ tem uma imprecisão inerente, por causa do rearranjo do pó no interior da matriz no início da compactação. Entretanto, considerando-se que este rearranjo representa apenas uma pequena parte da densificação total, o parâmetro $\boldsymbol{B}$ dá uma boa aproximação da densidade aparente inicial.

Na TAB. 6 são apresentados os valores encontrados para os parâmetros $\boldsymbol{A}$ e $\boldsymbol{B}$ (equação da reta) e de $\mathbf{R}$ (coeficiente de ajuste linear) em função da aplicação de cada uma das equações de compactação levantadas na literatura aos dados deste trabalho. Nota-se que na maioria das equações os coeficientes de correlação linear (R) foram superiores a 0,98.

A equação de Panelli e Ambrozio Filho foi a que melhor se ajustou aos dados de todas as amostras (Os valores de $\mathbf{R}$ ficaram entre 0,9993 e 0,9942).

A equação de Balshin também obteve elevados valores de $\mathbf{R}$, assim como a equação de Kawakita \& Lüdde, ficando a primeira entre 0,9991 e 0,9737 e a segunda entre 0,9991 e 0,9885.

A equação de Heckel apresentaria todos os valores de $\mathbf{R}$ acima de 0,999, porém estes são obtidos para pressões superiores a 200 MPa (Heckel alega que é a partir dessa pressão que a equação tem precisão), o que significa que a metade dos dados da pressão de compactação utilizada neste trabalho é ignorada. Para efeito de comparação, considerou-se também as pressões abaixo de $200 \mathrm{MPa}$, como foi feito para todas as outras equações, e os valores de $\mathbf{R}$ além de variar caem razoavelmente, ficando entre 0,9944 e 0,9607.

Outra equação que tem variação elevada entre os valores de $\mathbf{R}$ é a de $\mathrm{Ge}$, com $\mathbf{R}$ máximo de 0,9902 e mínimo de 0,9539 (este último o mais baixo de todas as equações aplicadas neste trabalho).

Apesar de alguns ótimos resultados fornecidos pelas equações da compactação avaliadas, investigou-se a possibilidade de se encontrar uma equação que se ajustasse ainda melhor aos dados deste trabalho. O raciocínio foi inspirado nas equações de Heckel e Panelli/Ambrozio Filho, que diferem apenas no expoente de $P$, ou seja, 1 na equação de Heckel e 0,5 na de Panelli/Ambrozio Filho. 
TABELA 6 - Coeficientes $\boldsymbol{A}$ e $\boldsymbol{B}$ das retas ajustadas aos dados segundo os modelos de compactação analisados neste trabalho. Os melhores coeficientes encontrados estão destacados em vermelho.

\begin{tabular}{|c|c|c|c|c|c|c|c|}
\hline $\begin{array}{c}\text { Mistura } \\
\mathrm{NbAl}\end{array}$ & & Balshin & Heckel & Kawakita & $\mathrm{Ge}$ & $\begin{array}{c}\text { Panelli \& } \\
\text { Ambrozio Fo }\end{array}$ & $\begin{array}{c}\text { Castagnet } \\
\& \\
\text { Leal Neto }\end{array}$ \\
\hline \multirow{3}{*}{$\begin{array}{c}30 \min \\
1 \% \\
L 1\end{array}$} & $A$ & $-0,1555$ & 0,0023 & 2,2764 & 0,1531 & 0,0487 & 0,0263 \\
\hline & $B$ & 2,2540 & 0,7214 & 89,3088 & $-0,2710$ & 0,5634 & 0,6157 \\
\hline & $\mathbf{R}$ & $-0,9855$ & 0,9783 & 0,9957 & 0,9563 & 0,9984 & 0,9996 \\
\hline \multirow{3}{*}{$\begin{array}{c}30 \min \\
1 \% \\
\mathrm{~L} 2\end{array}$} & $A$ & $-0,1890$ & 0,0023 & 1,900 & 0,1484 & 0,0471 & 0,0416 \\
\hline & $B$ & 2,3050 & 0,72145 & 34,59 & $-0,2690$ & 0,5622 & 0,5555 \\
\hline & $\mathbf{R}$ & $-0,9935$ & 0,97829 & 0,9981 & 0,9538 & 0,9991 & 0,9985 \\
\hline \multirow{3}{*}{$\begin{array}{c}30 \mathrm{~min} \\
2 \% \\
\text { L1 }\end{array}$} & $A$ & $-0,1539$ & 0,0023 & 2,2720 & 0,1485 & 0,0608 & 0,0332 \\
\hline & $B$ & 2,2607 & 0,7214 & 90,3028 & $-0,2690$ & 0,5458 & 0,6036 \\
\hline & $\mathbf{R}$ & $-0,9827$ & 0,9783 & 0,9958 & 0,9539 & 0,9990 & 0,9946 \\
\hline \multirow{3}{*}{$\begin{array}{c}30 \mathrm{~min} \\
2 \% \\
\mathrm{~L} 2\end{array}$} & $A$ & $-0,1922$ & 0,0037 & 2,0455 & 0,2144 & 0,0738 & 0,0399 \\
\hline & $B$ & 2,2680 & 0,7938 & 48,3386 & $-0,3017$ & 0,5553 & 0,6340 \\
\hline & $\mathbf{R}$ & $-0,9991$ & 0,9607 & 0,9991 & 0,9902 & 0,9991 & 0,9953 \\
\hline \multirow{3}{*}{$\begin{array}{c}1 \mathrm{~h} \\
1 \% \\
\mathrm{~L} 1 \\
\end{array}$} & $A$ & $-0,1565$ & 0,0028 & 2,303 & 0,1766 & 0,0484 & 0,0256 \\
\hline & $B$ & 2,2317 & 0,7939 & 243,99 & $-0,3050$ & 0,5949 & 0,6594 \\
\hline & $\mathbf{R}$ & 0,9855 & 0,9941 & 0,9967 & 0,9602 & 0,9942 & 0,9980 \\
\hline \multirow{3}{*}{$\begin{array}{c}\mathrm{h} \\
1 \% \\
\mathrm{~L} 2\end{array}$} & $A$ & $-0,1762$ & 0,0024 & 2,2632 & 0,1969 & 529 & 280 \\
\hline & $B$ & 2,3292 & 0,7670 & 143,1344 & $-0,3469$ & 0,5474 & 189 \\
\hline & $\mathbf{R}$ & $-0,9889$ & 0,9944 & 0,9979 & 0,9638 & 942 & 980 \\
\hline \multirow{3}{*}{$\begin{array}{c}\mathrm{h} \\
2 \% \\
\mathrm{~L} 1\end{array}$} & $A$ & $-0,1539$ & 0,0019 & 2,4619 & 0,1601 & 0,0418 & 0,0221 \\
\hline & $B$ & 2,2620 & 0,7714 & 194,6103 & $-0,2956$ & 0,6039 & 0,6583 \\
\hline & $\mathbf{R}$ & $-0,9907$ & 0,9853 & 0,9971 & 0,9710 & 0,9987 & 0,9998 \\
\hline \multirow{3}{*}{$\begin{array}{c}1 \mathrm{~h} \\
2 \% \\
\mathrm{~L} 2 \\
\end{array}$} & $A$ & $-0,1768$ & 0,0023 & 2,462 & 0,1812 & 0,0485 & 0,0258 \\
\hline & $B$ & 2,3572 & 0,7442 & 194,61 & $-0,3297$ & 0,5565 & 0,6177 \\
\hline & $\mathbf{R}$ & $-0,9950$ & 0,9827 & 0,9971 & 0,9757 & 0,9992 & 0,9998 \\
\hline \multirow{3}{*}{$\begin{array}{l}2 \mathrm{~h} \\
1 \% \\
\mathrm{~L} 1\end{array}$} & $A$ & $-0,1307$ & 0,00147 & 2,7601 & 0,1331 & 0,0324 & 0,0175 \\
\hline & $B$ & 2,1956 & 0,78314 & 296,6873 & $-0,2646$ & 0,6474 & 0,69144 \\
\hline & $\mathbf{R}$ & $-0,9842$ & 0,9882 & 0,9955 & 0,9659 & 0,9981 & 0,9997 \\
\hline \multirow{3}{*}{$\begin{array}{l}\mathrm{h} \\
1 \% \\
\mathrm{~L} 2 \\
\end{array}$} & $A$ & $-0,1279$ & 0,0014 & 2,8127 & 0,1286 & 0,0316 & 0,0167 \\
\hline & $B$ & 2,1875 & 0,9796 & 276,0461 & $-0,2581$ & 0,6419 & 0,6913 \\
\hline & $\mathbf{R}$ & $-0,9841$ & 0,9866 & 0,9952 & 0,9657 & 0,9985 & 0,9998 \\
\hline \multirow{3}{*}{$\begin{array}{c}2 \mathrm{~h} \\
2 \% \\
\mathrm{~L} 1 \\
\end{array}$} & $A$ & $-0,1317$ & 0,0016 & 2,7757 & 0,1360 & 0,0349 & 0,0185 \\
\hline & $B$ & 2,1713 & 0,7939 & 219,14 & $-0,2560$ & 0,6535 & 0,6991 \\
\hline & $\mathbf{R}$ & $-0,9896$ & 0,9825 & 0,9959 & 0,9721 & 0,9993 & 0,9995 \\
\hline \multirow{3}{*}{$\begin{array}{l}\mathrm{h} \\
2 \% \\
\mathrm{~L} 2\end{array}$} & $A$ & $-0,1287$ & 0,0016 & 2,7877 & 0,1348 & 0,0347 & 0,0183 \\
\hline & $B$ & 2,1530 & 0,8017 & 245,4897 & $-0,2515$ & 0,6606 & 0,7063 \\
\hline & $\mathbf{R}$ & $-0,9871$ & 0,9852 & 0,9958 & 0,9686 & 0,9988 & 0,9997 \\
\hline \multirow{3}{*}{$\begin{array}{c}2,5 \mathrm{~h} \\
1 \% \\
\mathrm{~L} 1\end{array}$} & $A$ & $-0,0993$ & 0,0014 & 3,1341 & 0,1034 & 0,0289 & 0,0155 \\
\hline & $B$ & 2,0484 & 0,7825 & 147,0634 & $-0,2052$ & 0,6810 & 0,7130 \\
\hline & $\mathbf{R}$ & $-0,9763$ & 0,9753 & 0,9912 & 0,9605 & 0,9992 & 0,9986 \\
\hline \multirow{3}{*}{$\begin{array}{c}2,5 \mathrm{~h} \\
1 \% \\
\mathrm{~L} 2 \\
\end{array}$} & $A$ & $-0,0994$ & 0,0014 & 3,0937 & 0,1049 & 0,0293 & 0,0157 \\
\hline & $B$ & 2,0518 & 0,7767 & 138,2365 & $-0,2091$ & 0,6749 & 0,7069 \\
\hline & $\mathbf{R}$ & $-0,9737$ & 0,9748 & 0,9913 & 0,9609 & 0,9993 & 0,9985 \\
\hline
\end{tabular}


Por meio de tentativa e erro, procurou-se obter um coeficiente de correlação que melhor se ajustasse aos dados deste trabalho, com base na variação do expoente de $P$. O valor encontrado foi igual a 0,6, a partir do qual $\mathbf{R}$ em nenhum caso foi abaixo de 0,9946 e, na maioria dos casos, superior aos coeficientes de correlação de todas as outras equações.

Esta equação é a seguinte:

$$
\ln \left(\frac{1}{1-D}\right)=A_{6} P^{0,6}+B_{6}
$$

Os resultados do ajuste para a nova equação estão apresentados na última coluna da TAB. 5 e nos gráficos das figuras 25, 26 e 27.

Em termos de precisão e ajuste, das quatorze condições de misturas compactadas neste trabalho, a equação de Castagnet/Leal Neto teve o melhor ajuste em nove, e a equação de Panelli/Ambrozio em cinco. 

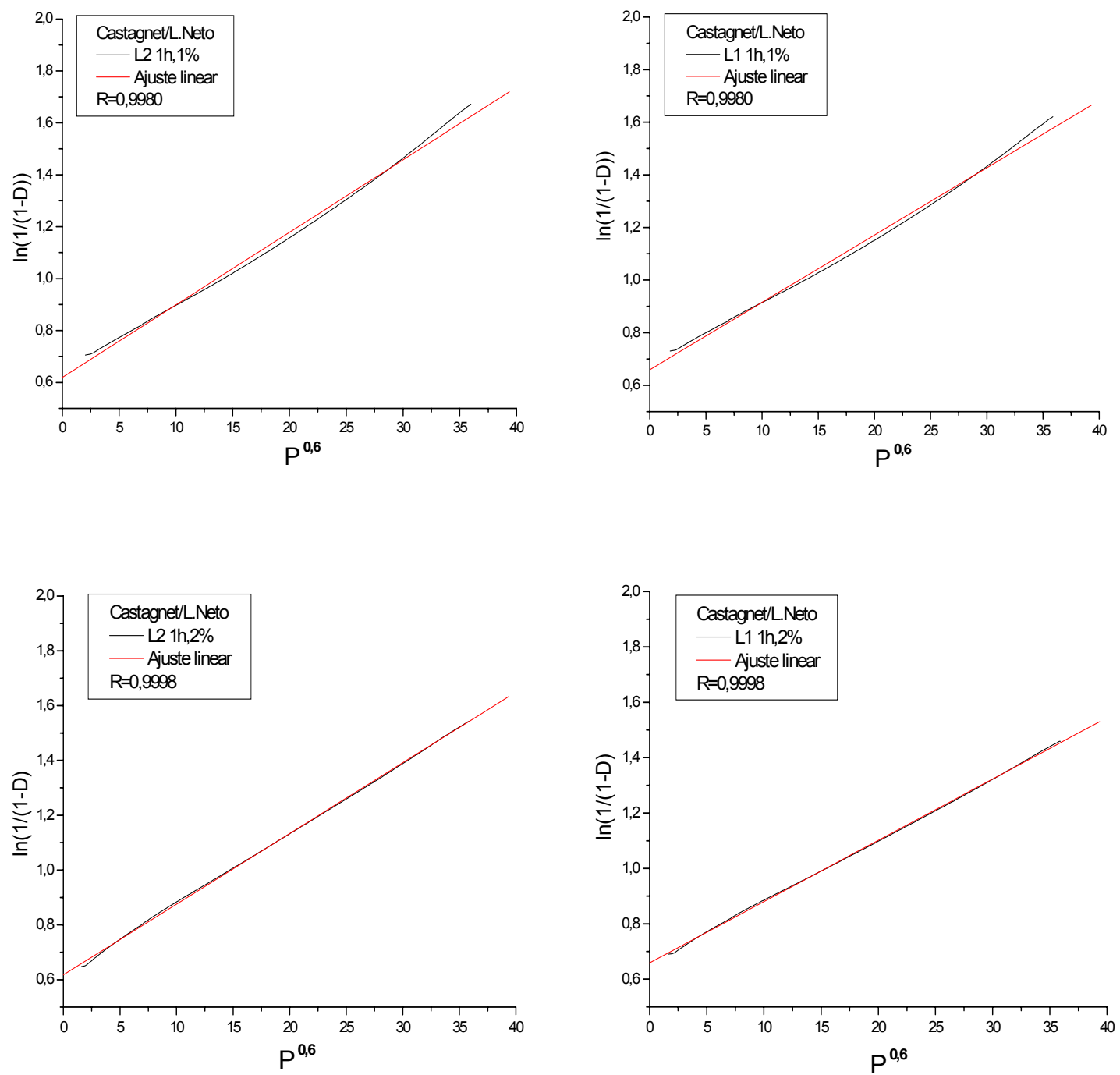

Figura 25- Curvas de aplicação da nova equação de compactação aos dados das amostras deste trabalho. Os coeficientes de correlação linear $(R)$ estão indicados em cada gráfico. 

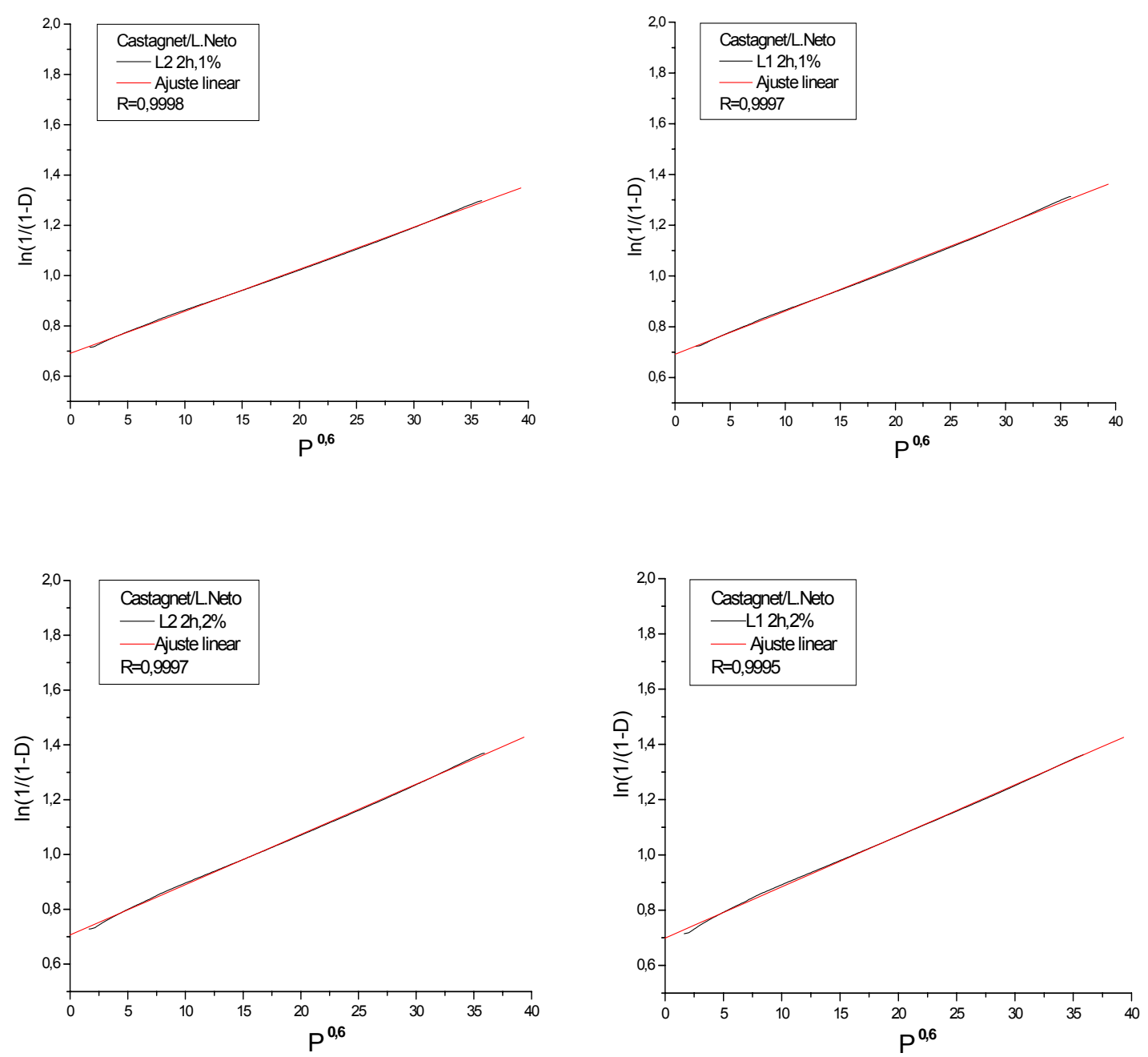

Figura 26- Curvas de aplicação da nova equação de compactação aos dados das amostras deste trabalho. Os coeficientes de correlação linear $(R)$ estão indicados em cada gráfico. 

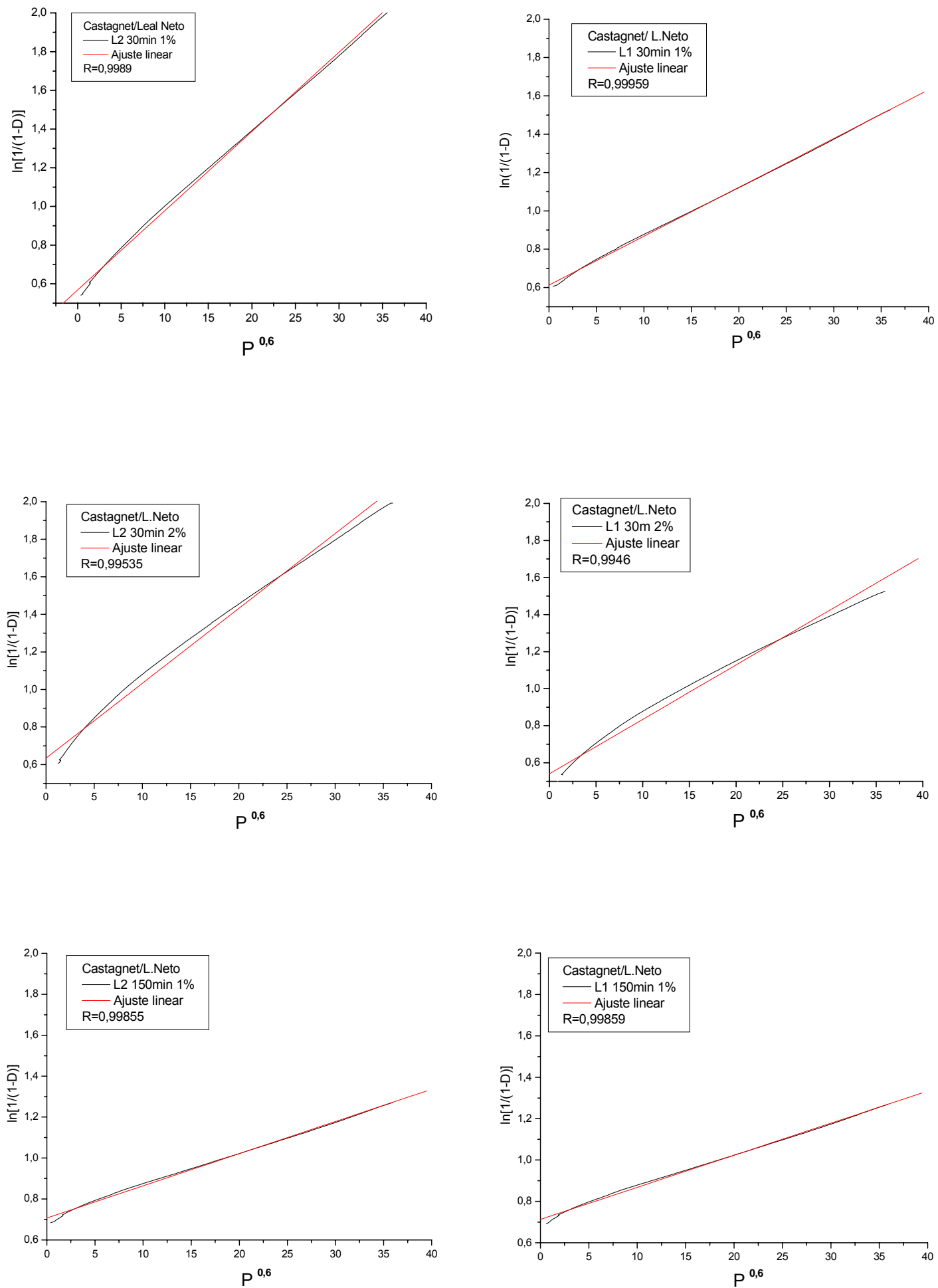

Figura 27- Curvas de aplicação da nova equação de compactação aos dados das amostras deste trabalho, nas condições de tempo de $0,5 \mathrm{~h}$ (quatro gráficos superiores) e 2,5 h (gráficos inferiores). Os coeficientes de correlação linear (R) estão indicados em cada gráfico. 


\section{CONCLUSÕES}

A ativação mecânica e, particularmente, o uso de ACP, exercem forte influência na compressibilidade das misturas $\mathrm{Nb}-\mathrm{Al}$ aqui investigadas. A comparação da compressibilidade das amostras em função do tempo de moagem e da quantidade de ACP deve levar em conta o estágio de ativação mecânica e o tamanho das partículas/agregados. De maneira geral, o aumento do tempo de moagem favorece a homogeneização das misturas ativadas mecanicamente, diminuindo a compressibilidade, provavelmente em razão do maior encruamento. O aumento da quantidade de ACP retarda ou desfavorece a formação de agregados, diminuindo seu tamanho e, consequentemente, a compressibilidade.

É necessário levar em conta a forma e o tamanho iniciais das partículas formadoras das misturas, uma vez que a quantidade de ACP atua com mecanismos específicos para estes fatores. Partículas maiores e/ou de forma regular têm menor área de superfície específica, fazendo com que o ACP atue com maior eficiência, desfavorecendo a soldagem e a formação de agregados. Partículas menores e/ou irregulares, com maior área de superfície, têm a eficiência da atuação do ACP reduzida e com isso há aumento da fricção interpartículas, maior soldagem e a formação de agregados.

Foi proposta uma nova equação de compactação que se ajustou melhor à compactação das misturas de pós utilizadas neste trabalho, com coeficientes de correlação linear sempre superiores a 0,9946. Os resultados aqui obtidos pela aplicação das diversas equações são específicos às condições das misturas de $\mathrm{Nb}-\mathrm{Al}$ avaliadas neste trabalho. Num contexto geral, não se pode afirmar qual equação é mais precisa, pois o ajuste das equações pode ser melhor ou pior, dependendo do tipo e/ou condição do material. 


\section{SUGESTÕES PARA TRABALHOS FUTUROS}

A partir do exposto, os seguintes temas podem ser sugeridos:

- Ampliar o estudo para outros pós metálicos e cerâmicos;

- Ampliar o estudo mediante emprego de outros agentes controladores de processo e verificar uma possível dependência com o expoente de P;

- Buscar correlacionar os resultados de compressibilidade com os de síntese por reação das misturas ativadas;

- Avaliar a expansão elástica (densidade após extração da matriz) das amostras compactadas em algumas pressões. 


\section{REFERÊNCIAS BIBLIOGRÁFICAS}

1 WESTBROOK, J.H.; FLEICHER, R.L. (Eds.) Intermetallic compounds: principles and practice. Chichester, England.: John Wiley \& Sons,. v.1: Principles,. 1994

2 SAUTHOFF, G. Intermetallics. Weinheim, New York, Basel, Cambridge, Tokyo.: VHC, 1995.

3 WILLIAMS, J.C. Structural intermetallics. The Minerals, Metals \& Materials Society, 1997.

4 AOKI, K.; IZUMI, O. Improvement in the room temperature ductility of the $\mathrm{L}_{2}$ type intermetallic compound $\mathrm{Ni}_{3} \mathrm{Al}$. J. Jpn. Inst. Met., v.43, p.1190-1196, 1979.

5 LEAL NETO, R.M.; FERREIRA, P.I. Reaction sintering of Nb-Ni-Al intermetallic alloys. Mat. Sci. Eng. A., v.193, p. 549-555, 1995.

6 SRITHARAN, T.; MURALI, S. Synthesis of ternary intermetallics by exothermic reaction. J. Mat. Proces. Technol., v.113, p. 469-473, 2001.

7 LEE, S.H.; LEE, J.H.; LEE, Y.H.; SIN, D.H.; KIM, Y.S. Effect of heating rate on the combustión síntesis of intermetallics. Mat. Sci. Eng. A., v.281, p. 275-285, 2000 .

8 MUNIR, Z.A.; ANSELMI-TAMBURINI, U. Self-propagating exothermic reactions: The Syntesis of High-Temperature materials by Combustion. Mat. Sci. Reports, v.3, p. 277-365, 1989.

9 BARTH, E.P.; TIEN, J.K.; UEJO, S.; KAMBARA, S. High temperature strengh of niobium aluminide intermetallics. Mat. Sci. Eng. A., v.153, p.348-401, 1992.

10 KACHELMYER, C.R.; ROGACHEV, aS.; VARMA, A. Mechanistic and processing studies in combustion synthesis of niobium aluminides. J. Mater. Res., v.10, n.9, p.2260-2270, 1995.

11 VARMA, A.; MUKASYAN, A.S. Combustion synthesis of advanced materials. ASM Handbook, v.7, p.523-540, 1998.

12 LEAL NETO, R.M. Síntese por combustão do $\mathrm{NbAl}_{3}$ e de ligas $\mathrm{Nb}-\mathrm{Ni}$-Al. São Paulo: 1998. Tese (Doutorado)- Instituto de Pesquisas Energéticas e Nucleares, São Paulo. 
13 MIURA, S.; TOMONORI, ${ }^{\circ}$; MISHIMA, Y. Amount of liquid phase during reaction synthesis of nickel aluminides, Intermetallics, v.5, p. 45-49, 1997.

14 HIBINO, A.; MATSUOKA, S.; KIUCHI, M. Synthesis and sintering of $\mathrm{Ni}_{3} \mathrm{Al}$ intermetallic compound by combustion synthesis process. J. Mat. Proces. Technol., v.112, p. 127-135, 2001.

15 SURYANARAYANA, C. Mechanical alloying and milling. Prog. Mat. Sci., v.46, p. 1-184, 2001.

16 BENJAMIN, J.S. Mechanical Alloying. Scientific american, v.234, n. 5, p. 4048, 1976.

17 BENJAMIM, J.S.; VOLIN, T.E. Mechanisms of mechanical alloying. Metal Trans., v.5, p.1929-1934, 1974.

18 BOLDYREV, V.V. Mechanical activation and its application in technology. Mat. Sci. Forum, v.269-272, p.227, 1998.

19 GAFFET, E.; MALHOUROUX-GAFFET, N. Nanocrystalline $\mathrm{MoSi}_{2}$ phase formation induced by mechanically activated annealing. J. of Alloys and Comp., v.205, p.27-34, 1994.

20 SHAW, M.C. Mechanical Activation - A newly developed chemical process. $\boldsymbol{J}$. App. Mech., v.3, p. 37-44, 1948.

21 STEINIKE, U.; TKACOVA, K. Mechanochemistry of solids- Real Structure and Reactivity. J. Mat. Synth. Proc., v.8, p. 197-203, 2000.

22 SURYANARAYANA, C.; KOCH, C.C. Nanocrystalline materials - Current research and future directions. Hyperfine inter., v.130, p. 5-44, 2000.

23 TAKACS, L. Self-sustaining reactions induced by ball milling. Progr. Mat. Sci., v.47, p. 355-414, 2002.

24 FERNANDES, B.B.; RODRIGUES, G.; SILVA, G.; RAMOS, E.C.T.; NUNES, C.A.; SANDIM, H.R.Z.; RAMOSA, A.S. On the $T_{2}$-phase formation in mechanically alloyed $\mathrm{Nb}-\mathrm{Si}$ and $\mathrm{Nb}-\mathrm{Si}-\mathrm{B}$ powders. J. Alloys comp., v.434, p.530-534, 2007.

25 Di, L.M.; BAKKER, H.; Phase transformation of the compound $\mathrm{V}_{3} \mathrm{Ga}$ induced by mechanical grinding. J Phys C: Condens. Matter, v.3, p. 3427-32, 1991 
26 HARRINGA, J.L.; COOK, B.A.; BEAUDRY, B.J.; Effects of vial shape on the rate of mechanical alloying in Si-Ge. J. Mater. Sci., v.27, p.801-804, 1992

27 LAI, M.O., LU, L. Mechanical alloying, Boston, MA: Kluwer Academic Publishers, 1998.

28 SURYANARAYANA, C.; IVANOV, E.; NOUFI, R.; CONTRERAS, M.A.; MOORE, J.J. Phase selection in a mechanically alloyed Cu-In-Ga-Se powder mixture. J. Mater. Res., v.14, p.377-83, 1999

29 GUO, W.; IASONNA, A.; MAGINI, M.; MARTELLI, S.; PADELLA, F. Synthesis of amorphous and metastable Ti40Al60 alloys by mechanical alloying of elemental powders. J. Mater. Sci., v.29, p. 2436-44, 1994.

30 YUANZHENG, Y.; YOULAN, Z.; QIAOSHEN, L.; XUEMING, M.; YUANDA, D.; GENMIAO, W.; SHIQIANG, W. Mechanical alloying, fine structure and thermal decomposition of nanocrystalline FCC-Fe60Cu40. Physica B., v.293 p.249-259, 2001

31 KALOSHKIN, S.D.; TOMLIN, I.A.; ANDRIANOV, G.A.; BALDOKHIN, U.V.; SHELEKHOV, E.V. Phase transformations and hyperfine interactions in mechanically alloyed $\mathrm{Fe}-\mathrm{Cu}$ solid solutions. Synthesis and properties of mechanically alloyed and nanocrystalline materials, v.235, p.565-70, 1997.

32 SURYANARAYANA, C. Does a disordered $\mathrm{y}$-TiAl phase exist in mechanically alloyed Ti-Al powders? Intermetallics, v.3, p.153-160, 1995.

33 CHIN, Z.H.; PERNG, T.P. Instant formation of Ti $\mathrm{N}$ by reactive milling of $\mathrm{Ti}$ in nitrogen; Mater. Sci. Forum, p. 235-238:121-126, 1997.

34 KIS-VARGA, BEKE, D.L. Phase transitions in Cu-Sb systems induced by ball milling. Mater. Sci. Forum, v.225, p.465-70, 1996.

35 SURYANARAYANA, C.; CHEN, G.H.; FROES, F.H. Milling maps for phase identification during mechanical alloying. Scripta Metall. Mater., v.26, p.17271732, 1992.

36 GAUTHIER, V.; JOSSE, C.; BERNARD, F.; GAFFET, E.; LARPIN, J.P. Synthesis of niobium aluminides using mechanically activated selfpropagating high-temperature synthesis and mechanically activated annealing process. Mat. Sci. Eng., v.265, p.117-128, 1999.

37 LEAL NETO, R.M.; ROCHA, C.J. Effect of the high-energy ball milling on the combustion synthesis of $\mathrm{NbAl}_{3}$. Key Eng. Mat., v.189-1, p.567-572, 2001. 
38 TAKACS, L. Self-sustaining reactions induced by ball milling. Prog. Mat. Sci., v.47, p.355-414, 2002.

39 PARK, H.S.; SHIN, K.S. Effect of mechanical alloying on combustion synthesis of $\mathrm{MoSi}_{2}$. J. Mater. Res., v.16, n.11. p. 3060-3068, 2001.

40 LIU, Z.G.; GUO, J.T. Formation mechanism of TiC by mechanical alloying. Appl. Physt. Lett., v.65, p. 2666-2668, 1994

41 SCHWARTZKOPF, P. Powder metallurgy: its physics and applications, Macmillan, New York, 1947.

42 ISTÚRIZ, A.; RIERA, M.D.; PRADO, J.M. Estudio experimental del llenado de moldes pulvimetalúrgicos. Rev. Met. Madrid, v. Extr., p.181-186, 2005

43 SEELIG, P.R.; WULFF,Y J, The pressing operation in the fabrication of articles by powder metallurgy. Trans. AIME, v.166, p.492-500, 1946.

44 FISCHMEISTER, H.F.; ARZT, E.; OLSSON, L.R. Particle deformation and sliding during compaction of spherical powders: a study by quantitative metallography. Powder metall., v.21, p.179-187, 1978.

45 AYDIN, I.; BRISCOE, B.J.; OZKAN, N. Modeling of powder compaction- a review. MRS Bulletin, v.22, p.45-51,. 1997.

46 GERMAN, R.M. Powder metallurgy of iron and steel, New York, NY: John Wiley \& Sons, 1998.

47 TIEN, Y.M.; WU, PLL.; CHU, C.A.; CHUANG, W.S.; WU, L.H. The friction-free compressibility curve of bentonite block. Phisics and chemistry on the earth, v. 32, p.809-819, 2007.

48 GERMAN, R.M. Powder metall. Sci. $2^{\text {nd }}$ ed., Princeton, NJ: Metal Powder Industries Federation, 1994.

49 BALSHIN, M.J. Powder metall., Moscow, 1948. Apud KAYTBAY, S.H M., DUDROVÁ, E. Contribution to analisys of compaction of metal powders, Acta Metallurgica Slovaca, n.1, p.42-48, 2004.

50 HECKEL, R.W. Density-pressure relationships in powder compaction. Trans. Metall. Soc., AIME v.221, p.671-675, 1961. 
51 KAWAKITA, K., LÜDDE, K. Some considerations on powder compression equations. Powder technol., v.4, p. 61-68, 1971.

52 GE, R. A further study of a new powder compaction equation. Powder metall. Sci.\& technol., (India), v.6, p.20-24, 1995.

53 PANELLI, R.; AMBROSIO FILHO, F. A study of a new phenomenological compacting equation. Powder technol., v.114, p.255-261, 2001.

54 STEARIC ACID- Banco de dados. Disponível em:<a href="http://science.jrank. org/ pages/6482/Stearic-Acid.html">Stearic Acid</a>. Acesso em 12 fev. 2008.

55 RAZAVI HESABI, Z.; HAFIZPOUR, H.R.; SIMCHI, A. An investigation on the compressibility of aluminum/nano-composite powder prepared by blending and mechanical. Mat. Sci. Eng., v.454, p.89-98, 2007.

56 ROCHA, C.J. Mecanismos de ativação mecânica de misturas de nióbio e alumínio para a síntese por reação do $\mathrm{NbAl}_{3}, 2008$. Tese (Doutorado) Instituto de pesquisas energéticas e nucleares, São Paulo.

57.ASTM Standard B212 1999 (2006), "Standard Test Method for Apparent Density of Free-Flowing Metal Powders Using the Hall Flowmeter Funnel", ASTM International, West Conshohocken, PA. 